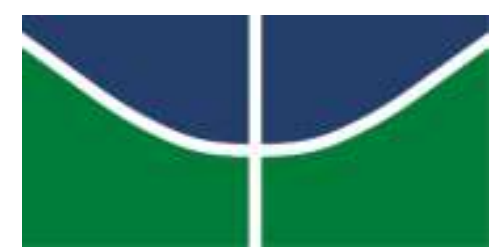

UNIVERSIDADE DE BRASÍLIA

INSTITUTO DE CIÊNCIAS HUMANAS - IH

DEPARTAMENTO DE GEOGRAFIA

PROGRAMA DE PÓS GRADUAÇÃO EM GEOGRAFIA

FELIPE LUIS LACERDA DE CARVALHO CIDADE MATOS

ANÁLISE DAS TAXAS ANUAIS DE DESMATAMENTO NA AMAZÔNIA

LEGAL A PARTIR DA RELAÇÃO ENTRE AUTOS DE INFRAÇÃO E ÁREA DESMATADA NO PERÍODO 2000-2014

BRASÍLIA/DF 
FELIPE LUIS LACERDA DE CARVALHO CIDADE MATOS

\title{
ANÁLISE DAS TAXAS ANUAIS DE DESMATAMENTO NA AMAZÔNIA LEGAL A PARTIR DA RELAÇÃO ENTRE AUTOS DE INFRAÇÃO E ÁREA DESMATADA NO PERÍODO 2000-2014
}

\author{
Dissertação apresentada ao programa de Pós- \\ Graduação em Geografia, Departamento de \\ Geografia, Instituto de Ciências Humanas da \\ Universidade de Brasília como parte dos \\ requisitos para obtenção do grau de Mestre em \\ Geografia.
}




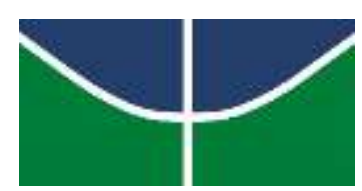

UNIVERSIDADE DE BRASÍLIA

INSTITUTO DE CIÊNCIAS HUMANAS - IH

DEPARTAMENTO DE GEOGRAFIA

PROGRAMA DE PÓS GRADUAÇÃO EM GEOGRAFIA

FELIPE LUIS LACERDA DE CARVALHO CIDADE MATOS

\section{ANÁLISE DAS TAXAS ANUAIS DE DESMATAMENTO NA AMAZÔNIA LEGAL A PARTIR DA RELAÇÃO ENTRE AUTOS DE INFRAÇÃO E ÁREA DESMATADA NO PERÍODO 2000-2014}

Dissertação apresentada ao Programa de Pós-Graduação em Geografia, Departamento de Geografia, Instituto de Ciências Humanas da Universidade de Brasília como parte dos requisitos para obtenção do grau de Mestre em Geografia.

Orientador: Prof. Dr. Valdir Adilson Steinke

Banca Examinadora:

Prof. Dr. Valdir Adilson Steinke - Orientador

Departamento de Geografia - UnB

Prof. Dr. Edson Eyji Sano - Membro Externo

Instituto Brasileiro do Meio Ambiente e dos Recursos Naturais Renováveis - IBAMA

Profa. Dra. Anne-Elizabeth Laques

IRD - França

Profa. Dra. Waleska Valença Manyari - Suplente

Departamento de Geografia - UnB

Aprovado em 23 de fevereiro de 2016. 


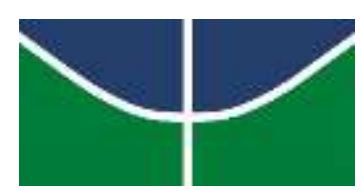

UNIVERSIDADE DE BRASÍLIA

INSTITUTO DE CIÊNCIAS HUMANAS - IH

DEPARTAMENTO DE GEOGRAFIA

PROGRAMA DE PÓS GRADUAÇÃO EM GEOGRAFIA

DISSERTAÇÃO DE MESTRADO

\section{FICHA CATALOGRÁFICA}

\section{MATOS, FELIPE LUIS LACERDA DE CARVALHO CIDADE}

Análise das Taxas Anuais de Desmatamento na Amazônia Legal a partir da Relação entre Autos de Infração e Área Desmatada no período entre 2000 e 2014. 90 p. (UnB - IH - GEA, Mestre, Geografia, Análise de Sistemas Naturais, 2016).

Dissertação de Mestrado - Universidade de Brasília. Instituto de Ciências Humanas / Departamento de Geografia

1. Amazônia Legal

3. Combate e Controle do Desmatamento
2. Desmatamento

4. Dinâmica do Desmatamento

É concedida à Universidade de Brasília permissão para reproduzir cópias dessa dissertação e emprestar ou vender tais cópias somente para propósitos acadêmicos e científicos. O autor reserva outros direitos de publicação e nenhuma parte desta dissertação de mestrado pode ser reproduzida sem a autorização do autor por escrito. 
DEDICATÓRIA

Dedico esta dissertação a todos aqueles que lutam e trabalham incansavelmente pela preservação da Floresta Amazônica. 


\section{AGRADECIMENTOS}

A Deus, por sempre proteger e abençoar minha vida;

À minha linda e amada esposa, Carla Nabarrete, por sempre me dar força e apoiar em todos os meus projetos e ideias;

À minha amada mãe, Ana Maria Matos, pessoa de muita força e fé que está sempre pronta para nos apoiar em tudo que for necessário;

Ao meu pai, Paulo Roberto Matos, pela excelente base que me deu em minha infância e adolescência;

À minha irmã Ana Paula Matos e meus sobrinhos lindos Cauê e Davi que, a cada dia que passa, alegram ainda mais minha vida;

Ao meu Orientador Valdir Adilson Steinke, por ter aceito e contribuído na realização desse desafio;

Ao IBAMA, através dos senhores Luciano de Meneses Evaristo - Diretor de Proteção Ambiental do Ibama, George Porto Ferreira - Coordenador Geral de Monitoramento Ambiental e Edson Eyji Sano - Chefe do Centro de Sensoriamento Remoto, por terem me concedido a oportunidade da licença capacitação para realização deste trabalho;

A todos os colegas do Centro de Sensoriamento Remoto - CSR, em especial aos amigos Daniel Freitas, Rodrigo Antônio de Souza e Werner Gonçalves, por serem excelentes companheiros em nossa rotina de trabalho;

A todos os meus amigos de infância da grande e eterna 315 norte, aos amigos da graduação em Geografia da Universidade de Brasília e do Triathlon que com certeza contribuem e contribuíram para uma vida muito feliz;

À Maria Luiza Souza - Malu, antiga Coordenadora de Operações do Ibama e atual Gerente Executiva do IBAMA em Santarém - PA, pelo apoio na obtenção de dados importantes para a elaboração da pesquisa;

A todos os funcionários do Departamento de Geografia da Universidade de Brasília. 
Se você está tentando alcançar algo, haverá bloqueios. Eu os encontrei, todo mundo os encontrou. Mas obstáculos não podem te parar. Se você topar com uma parede, não vire e desista. Descubra como escalá-la, passe por ela, trabalhe nisso.

Michael Jordan 


\section{RESUMO}

O desmatamento é uma das temáticas ambientais mais discutidas tanto dentro como fora do mundo acadêmico e o Brasil, como detentor de grande parte da Floresta Amazônica, é peça chave nessa discussão. Essa dissertação de mestrado tem por objetivo analisar a relação existente entre a lavratura de autos de infração e as taxas anuais de desmatamento, isto é, se a partir da implantação de medidas mais efetivas de combate e controle do desmatamento, através da presença dos órgãos do Estado, nas regiões onde ele ocorre, ocasionará uma diminuição nas taxas anuais de desmatamento. Foi analisada a influência que o PPCDAM - Plano de Ação para a Prevenção e Controle do Desmatamento na Amazônia Legal - teve na queda das taxas de desmatamento após sua implantação. A hipótese principal do trabalho foi confirmada e foi percebido que, a partir da maior presença dos órgãos do governo nas regiões mais críticas para o desmatamento, medida através da lavratura de autos de infração, foi importante para a diminuição dos índices de desmatamento no Brasil a partir do ano de 2005. A área de estudo foi sete dos nove estados da Amazônia Legal (Acre, Amazonas, Maranhão, Mato Grosso, Pará, Rondônia e Tocantins) que tem parte do seu território dentro do Arco do Desflorestamento. Os dados utilizados na pesquisa foram: Quantidade de Autos de Infração relativos a Flora lavrados pelo IBAMA e Taxa de Desmatamento medida pelo PRODES/INPE. O método de trabalho foi baseado na criação do índice de multas por $\mathrm{km}^{2}$ que é obtido através da divisão entre a quantidade de autos de infração lavrados pela taxa de desmatamento oficial. Como resultados tivemos que, nos anos seguintes ao lançamento do PPCDAM, na maior parte dos anos, em todos os Estados analisados o índice de multas por $\mathrm{km}^{2}$ foi maior do que no período anterior mostrando que a presença do órgão fiscalizador teve importância na queda da taxa de desmatamento no Brasil nos últimos dez anos.

Palavras Chave: Amazônia Legal, Desmatamento, Combate e Controle do Desmatamento, Dinâmica do Desmatamento. 


\begin{abstract}
Deforestation is one of the most discussed environmental issues within and outside the academic world. Brazil, as the holder of most of the Amazon Forest, is a key player in this discussion. This M.Sc. thesis aims to analyze the relationship between the environmental infraction notice and annual deforestation rate. In other words, we want to analyze if the adoption of more effective procedures of combat and control of deforestation, through the presence of government agencies in regions where deforestation occurs, will decrease the annual rates of deforestation. We analyzed the influence of PPCDAM - Action Plan for Prevention and Control of Deforestation in the Legal Amazon - in the decreasing of deforestation rates after its implementation. The main hypothesis of this study was confirmed. More intensive presence of government agencies in critical regions in terms of deforestation, measured by the number of issuances of environmental infraction notices, was important to reduce deforestation rates in Brazil from the year 2005. The study area corresponded to seven states of the Legal Amazon (Acre, Amazonas, Maranhão, Mato Grosso, Pará, Rondônia and Tocantins) that is part of Arch of Deforestation. The data set used in this study was: the number of environmental infraction notices regarding flora issued by IBAMA and the deforestation rate estimated by PRODES/INPE. The methodological approach was based on the analysis of the index relating the amount of fines per square kilometer, obtained by dividing the amount of infraction notices by the official deforestation rate. As a result, we observed that, in the years following the PPCDAM, in most of the years and in all states analyzed, the index of fines per square kilometer was higher than in the previous periods of PPCDAM. This shows that the presence of the government inspection agency was important to decrease the deforestation rate in Brazil in the past ten years.
\end{abstract}

Keywords: Legal Amazon, Deforestation, Prevention and Control of Deforestation, Deforestation Dynamics. 


\section{SUMÁRIO}

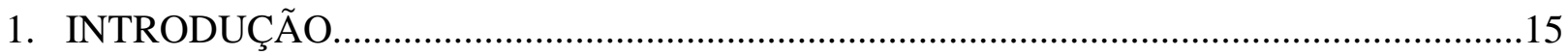

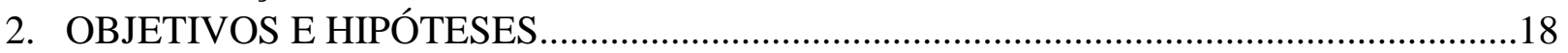

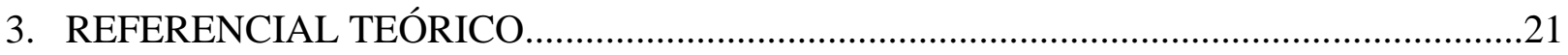

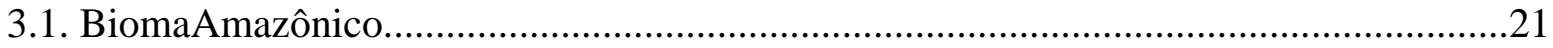

3.1.1. Caracterização do Bioma.......................................................................... 21

3.1.2. Ocupação Territorial do Bioma na segunda metade do século XX.....................23

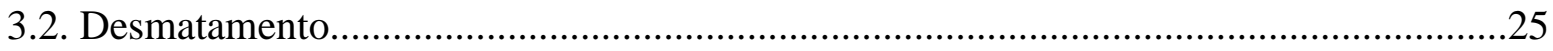

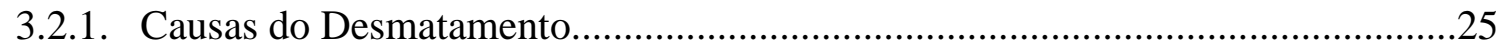

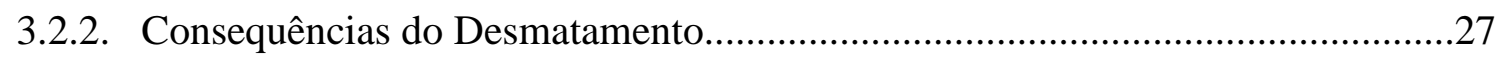

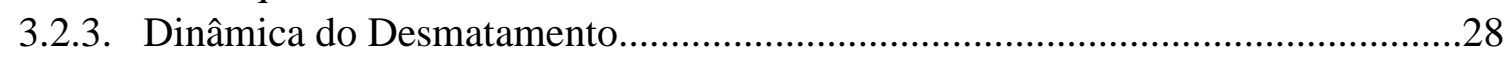

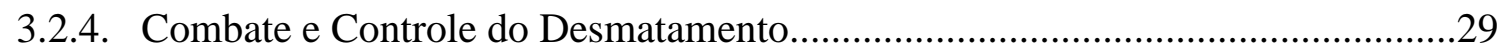

3.3. Políticas Governamentais de Combate ao Desmatamento Ilegal....................................32

3.3.1. Plano de Ação para a Prevenção e Controle do Desmatamento na Amazônia

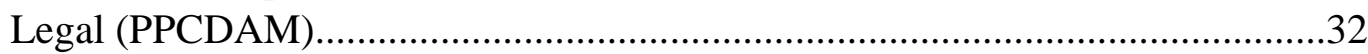

3.3.2. Resultados do Plano de Ação para a Prevenção e Controle do Desmatamento na Amazônia Legal (PPCDAM) ........................................................................38

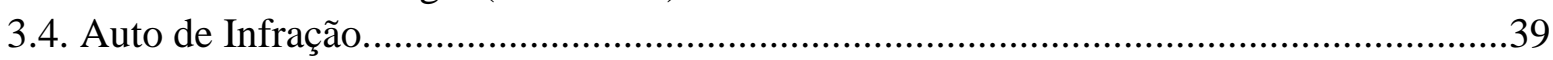

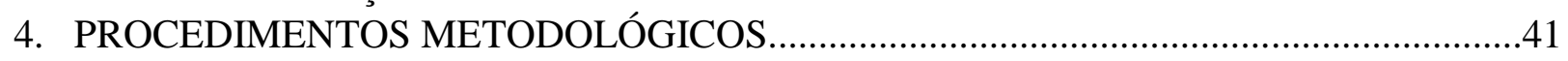

5. MATERIAIS E MÉTODOS ......................................................................................4

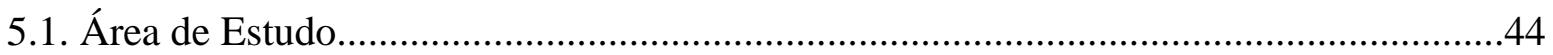

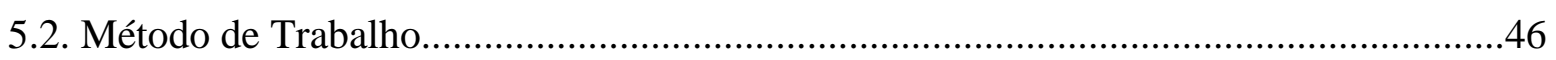

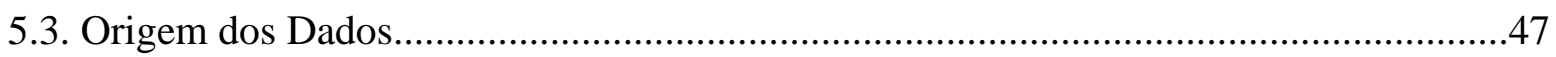

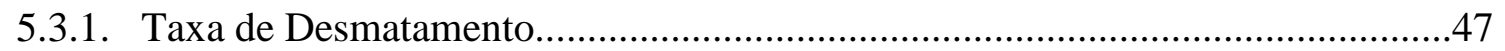

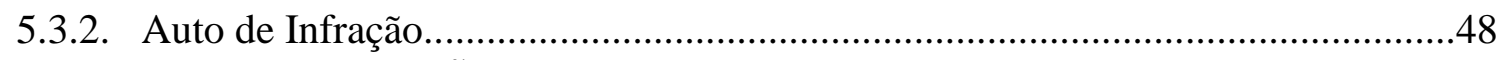

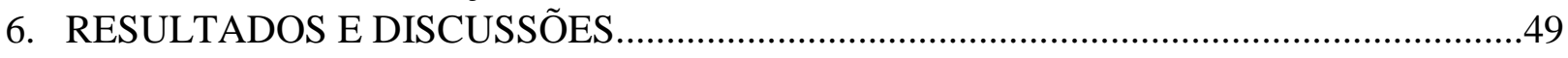

6.1. Amazônia Legal.....................................................................................................49

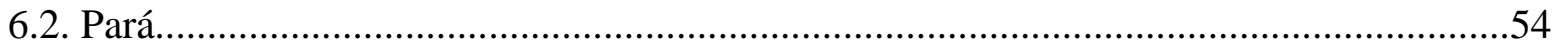

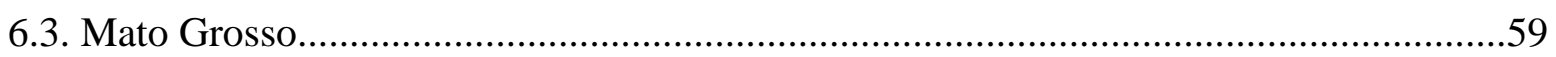

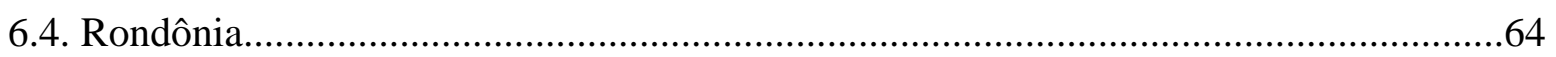

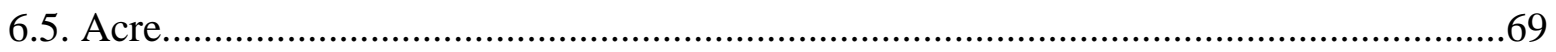

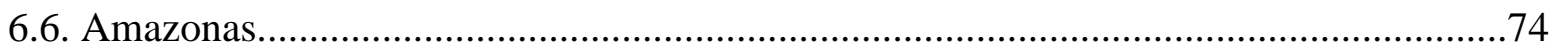

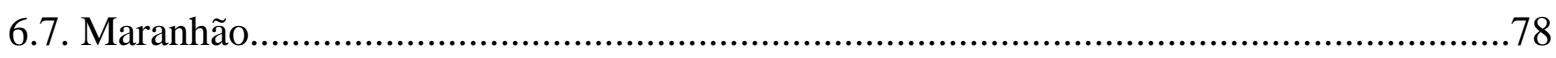

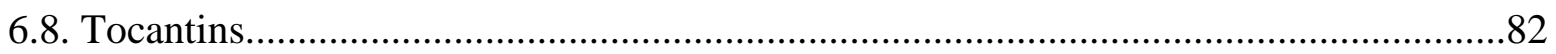

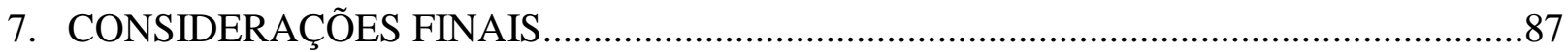

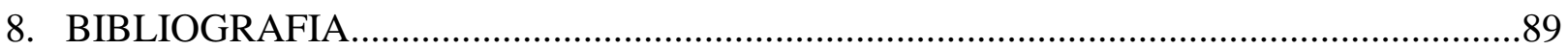




\section{LISTA DE TABELAS}

Tabela 1 - Taxa Anual de Desmatamento na Amazônia. .17

Tabela 2 - Tabela dos Subgrupos de Trabalho do PPCDAM...................................................34 


\section{LISTA DE GRÁFICOS}

Gráfico 1 - Taxa Anual de Desmatamento na Amazônia.........................................................17

Gráfico 2 - Taxa de Desmatamento na Amazônia Legal.....................................................51

Gráfico 3 - Autos de Infração Lavrados na Amazônia Legal.................................................52

Gráfico 4 - Índice de Multas por $\mathrm{Km}^{2}$ desmatado na Amazônia Legal..................................53

Gráfico 5 - Taxa de Desmatamento no Estado do Pará............................................................56

Gráfico 6 - Autos de Infração Lavrados no Estado do Pará.....................................................57

Gráfico 7 - Índice de Multas por $\mathrm{Km}^{2}$ desmatado no Estado do Pará........................................58

Gráfico 8 - Taxa de Desmatamento no Estado do Mato Grosso..............................................61

Gráfico 9 - Autos de Infração Lavrados no Estado do Mato Grosso.......................................62

Gráfico 10 - Índice de Multas por $\mathrm{Km}^{2}$ desmatado no Mato Grosso......................................63

Gráfico 11 - Taxa de Desmatamento no Estado de Rondônia.................................................66

Gráfico 12 - Autos de Infração Lavrados no Estado de Rondônia........................................67

Gráfico 13 - Índice de Multas por $\mathrm{Km}^{2}$ desmatado no Estado de Rondônia...........................67

Gráfico 14 - Taxa de Desmatamento no Estado do Acre....................................................... 71

Gráfico 15 - Autos de Infração Lavrados no Estado do Acre.................................................72

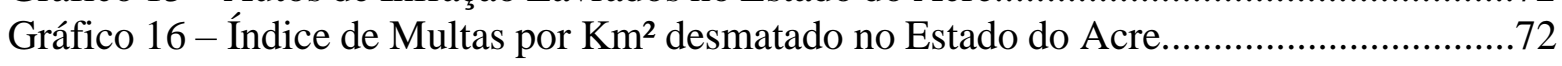

Gráfico 17 - Taxa de Desmatamento no Estado do Amazonas.............................................76

Gráfico 18 - Autos de Infração Lavrados no Estado do Amazonas........................................77

Gráfico 19 - Índice de Multas por $\mathrm{Km}^{2}$ desmatado no Estado do Amazonas............................77

Gráfico 20 - Taxa de Desmatamento no Estado do Maranhão...............................................80

Gráfico 21 - Autos de Infração Lavrados no Estado do Maranhão........................................81

Gráfico 22 - Índice de Multas por $\mathrm{Km}^{2}$ desmatado no Estado do Maranhão.........................81

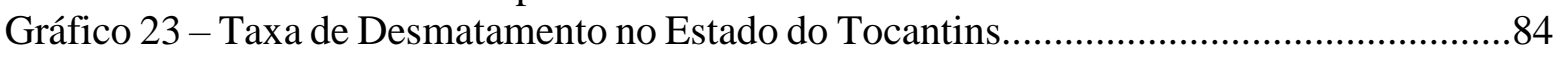

Gráfico 24 - Autos de Infração Lavrados no Estado do Tocantins...........................................85

Gráfico 25 - Índice de Multas por $\mathrm{Km}^{2}$ desmatado no Estado do Tocantins.........................85 


\section{LISTA DE MAPAS}

Mapa 1 - Desmatamento na Região do Arco do Desflorestamento....................................19

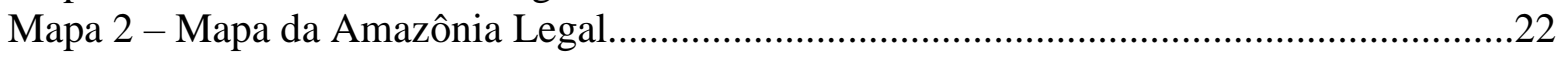

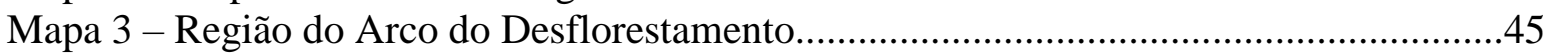

Mapa 4 - Mapa do Desmatamento na Amazônia Legal......................................................50

Mapa 5 - Mapa do Desmatamento no Estado do Pará...........................................................55

Mapa 6 - Mapa do Desmatamento no Estado do Mato Grosso.............................................60

Mapa 7 - Mapa do Desmatamento no Estado de Rondônia.................................................65

Mapa 8 - Mapa do Desmatamento no Estado do Acre.......................................................70

Mapa 9 - Mapa do Desmatamento no Estado do Amazonas.................................................75

Mapa 10 - Mapa do Desmatamento no Estado do Maranhão................................................79

Mapa 11 - Mapa do Desmatamento no Estado do Tocantins.................................................83 


\section{LISTA DE FIGURAS}

Figura 1 - Como será respondido o objetivo do trabalho......................................................... 


\section{Introdução}

Questões ambientais tomam conta das discussões na atualidade, desde conversas informais até grandes e importantes diálogos geopolíticos. Entre os temas que se destacam, considerado como um dos grandes vilões ambientais, temos o desmatamento de florestas nativas, em especial as florestas tropicais e o Brasil, como detentor de grande parte da floresta Amazônica, se configura como um dos principais atores nessa questão que chama a atenção de pesquisadores em todo o mundo.

O Brasil abriga, em seu território, diversos tipos de biomas que contribuem para que cada vez mais passe a ser olhado como um local importante para a tomada de decisões relativas à questão ambiental. No cenário internacional a preservação da Floresta Amazônica é tratada como de grande importância para todo o planeta por causa de sua enorme biodiversidade e porque vem sendo bastante desmatada e degradada nas últimas décadas.

A biodiversidade não é a única vítima do desmatamento. Outros serviços do ecossistema também são afetados. Erosão do solo, perda de nutrientes, perda das funções reguladoras da bacia hidrográfica e emissão de gases do efeito estufa são alguns dos mais prejudiciais danos ao ecossistema que são provocados pela exploração e degradação da floresta (Fearnside, 2005, in: Barreto, 2005, p.19).

A região é considerada a maior fonte brasileira de emissão de gás carbônico para a atmosfera, contribuindo para o agravamento do efeito estufa. Estudos recentes apontam que a dinâmica do desflorestamento na Amazônia envolve diferentes agentes e fatores causadores, conforme a área de abrangência e o momento de sua realização. Isso revela que o fenômeno é bastante complexo e não deve ser atribuído a um único agente ou fator. Na verdade, ele é a soma de um conjunto de forças que se combinam entre si e interagem sinergicamente (Machado, 2009, p.116).

O desmatamento na Floresta Amazônica teve no período entre 2004 e 2012, um processo de diminuição nos seus índices bastante considerável, saindo de $27.772 \mathrm{~km}^{2}$ no ano de 2004 para 4.571 $\mathrm{km}^{2}$ em 2012. Em 2013, a taxa de desmatamento voltou a aumentar chegando a $5.891 \mathrm{~km}^{2}$ de área desmatada. Em 2014, houve uma nova redução no índice atingindo a quantidade de $4.848 \mathrm{~km}^{2}$ desmatados. Todos esses números são baseados no Prodes / INPE (Projeto de Monitoramento da Floresta Amazônica Brasileira por Satélite do Instituto de Pesquisas Espaciais).

O Prodes / INPE é responsável pela divulgação do índice oficial de desmatamento na Floresta Amazônica Brasileira. O período Prodes vai de 01 de agosto a 31 de julho do ano seguinte. Desde o ano de 2004, a taxa oficial de desmatamento na Amazônia brasileira vinha diminuindo. No ano de 2008 , o total desmatado foi de $12.911 \mathrm{~km}^{2}$, chegando a $4.571 \mathrm{~km}^{2}$ no ano de 2012 , uma queda de mais 
de 50\% em apenas 4 anos. Em 2013 ocorreu um acréscimo de $29 \%$ em relação ao ano anterior o que representa um índice de $5.891 \mathrm{~km}^{2}$.

Por combate ao desmatamento entende - se a correta aplicação da lei ambiental aos praticantes do corte ilegal de árvores e também as medidas punitivas e protetivas que são tomadas para evitar tal prática. A adoção de políticas de combate ao desmatamento ilegal pelos órgãos do governo federal contribuiu de forma acentuada para que houvesse a redução dessas taxas.

As principais políticas de comando e controle, intervenções diretas do Estado que modificaram o comportamento dos desmatadores, foram: as operações Curupira (2005) e Arco de Fogo (2008) que combateram a exploração ilegal de madeira; Criação de Unidades de Conservação, somando mais 20 milhões de hectares aos mais de 80 milhões já existentes, totalizando 273 unidades de conservação, e a restrição aos produtos agropecuários advindos de propriedades nos municípios com maior incidência de desmatamento (Reydon, 2011, p.143).

Outra medida tomada é a tentativa de descapitalizar ou dificultar o acesso a programas de fomento do governo para as pessoas que praticam o desmatamento ilegal. Asfixiar financeiramente quem está na ilegalidade é uma tentativa de fazer com que essas pessoas busquem a legalidade.

Como forma de utilizar mecanismos econômicos para diminuir o desmatamento temos: Decreto 6321/07 que restringe a concessão de crédito pelos bancos e obriga os proprietários rurais dos municípios que mais desmatam a se recadastrarem; Operação Arco Verde (2008) e a Linha especial de crédito no âmbito do FNO (Fundo Constitucional de Financiamento do Norte), FNE (Fundo Constitucional de Financiamento do Nordeste) e FCO (Fundo Constitucional de Financiamento do Centro Oeste) para a recuperação de áreas degradadas, reflorestamento, manejo e regularização ambiental na Amazônia Legal.

O processo de desmatamento acarreta uma perda significativa na biodiversidade. Além desse fator, a supressão da floresta é responsável por impactar ambientalmente e socialmente a população local.

Os impactos do desmatamento incluem a perda de oportunidades para o uso sustentável da floresta, incluindo a produção de mercadorias tradicionais tanto por manejo florestal para madeira como por extração de produtos não madeireiros. O desmatamento também sacrifica a oportunidade de capturar o valor dos serviços ambientais da floresta. Como exemplo de serviços ambientais providos pela manutenção da floresta, podemos citar a biodiversidade, ciclagem da água e armazenamento de carbono. A sociodiversidade também é ameaçada pela perda da floresta, já que isto elimina culturas indígenas e extrativistas tradicionais tais como seringueiros (Fearnside, 2006, p.396). 
Como benefícios da redução das taxas de desmatamento, temos a redução dos incêndios florestais, da poluição do ar, da perda de biodiversidade, erosão do solo, entre outros (Nepstad, Soares-Filho, Merry, et.all, 2009, p.1351).

Nos últimos anos, a atuação do IBAMA como principal responsável pelo combate ao desmatamento, trouxe um resultado bastante positivo, tendo em vista a grande queda que houve nas taxas anuais de desmatamento no período entre 2004 e 2012. Em 2013, depois de vários anos de queda, voltou a ter um incremento na taxa de desmatamento e, em 2014, a taxa voltou a regredir novamente. Segue abaixo Tabela 1 e Gráfico $1 \mathrm{com}$ os valores anuais de desmatamento segundo o Prodes.

\begin{tabular}{|l|l|l|l|l|l|l|l|l|l|l|l|l|l|l|l|}
\hline ANO & 2000 & 2001 & 2002 & 2003 & 2004 & 2005 & 2006 & 2007 & 2008 & 2009 & 2010 & 2011 & 2012 & 2013 & 2014 \\
\hline $\begin{array}{l}\text { Área } \\
\left(\mathrm{Km}^{2}\right)\end{array}$ & 18.226 & 18.165 & 21.651 & 25.396 & 27.772 & 19.014 & 14.286 & 11.651 & 12.911 & 7.464 & 7.000 & 6.418 & 4.571 & 5.891 & 5.012 \\
\hline
\end{tabular}

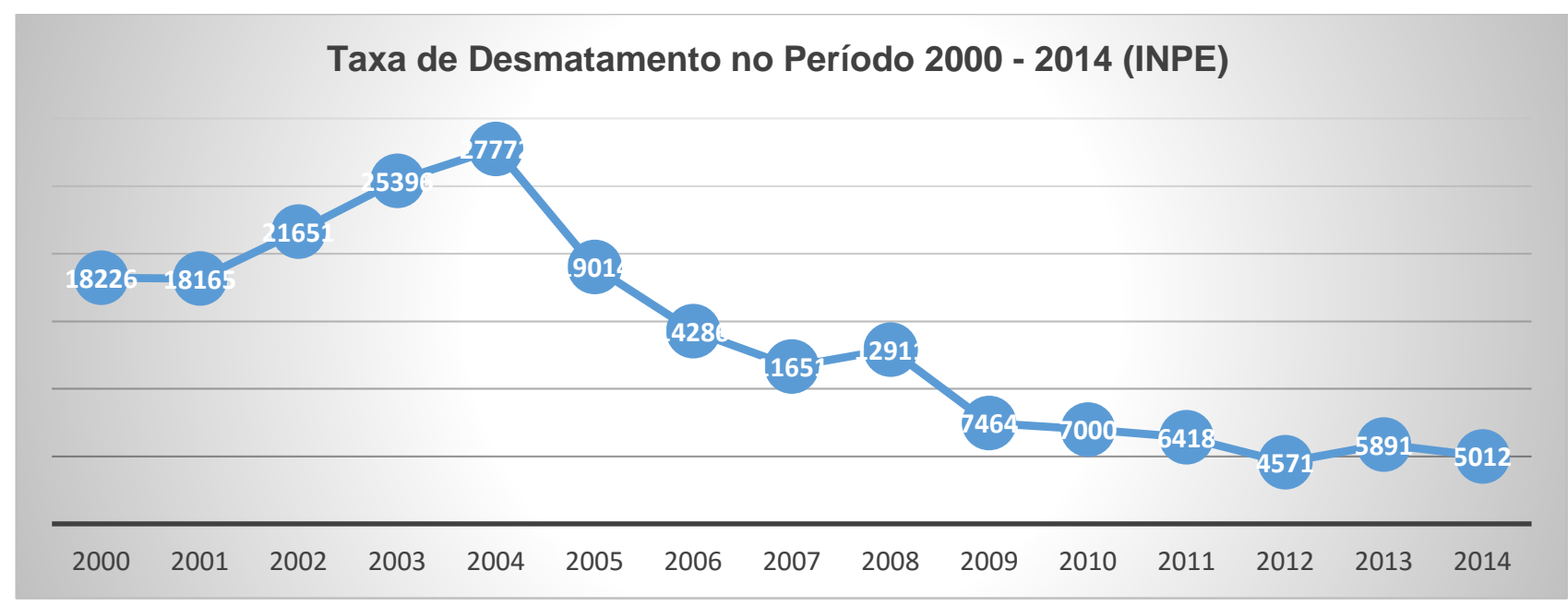

Gráfico 1: Taxa Anual de Desmatamento na Amazônia. Fonte: PRODES/INPE

A partir da análise da tabela e do gráfico acima, é possível perceber que, a partir do ano de 2004, ocorreu uma diminuição constante e sistemática nas taxas anuais de desmatamento. As taxas de desmatamento vinham em uma constante crescente e para tentar diminuir esses índices o governo federal lançou, em março de 2004, o Plano de Ação Para a Prevenção e Controle do Desmatamento na Amazônia Legal (PPCDAM).

O PPCDAM tinha como prioridade a viabilização de um novo modelo de desenvolvimento na região amazônica, baseado na inclusão social com respeito à diversidade cultural, a viabilização de atividades econômicas dinâmicas e competitivas e o uso sustentável de recursos naturais, mantendo o equilíbrio ecológico desse enorme patrimônio brasileiro (PPCDAM, 2004, p.7). 


\section{Objetivos e Hipóteses}

De modo geral, aceita-se que qualquer procedimento científico percorre usualmente os seguintes passos significativos: formulação da hipótese ou seleção e definição de condições e problemas; observação, coleta de dados e seus registros, através de métodos, técnicas e instrumentos adequados; análise e classificação dos dados em séries ou sequência uniformes e generalização ou formulação de teorias e leis científicas (Silva, 1978, p.73-74).

O objetivo geral do trabalho é analisar a relação entre a taxa de desmatamento e a quantidade de autos de infração lavrados pelo Ibama no período entre 2000 e 2014.

Para isso será feita a análise e comparação dos dados oficiais de desmatamento com as informações referentes aos autos de infração lavrados pelo Ibama com o intuito de determinar se existe e qual a relação entre a quantidade de autos de infração e a diminuição das taxas de desmatamento no período entre 2000 e 2014.

A região de análise serão os sete estados da Amazônia Legal (Acre, Amazonas, Maranhão, Mato Grosso, Pará, Rondônia e Tocantins) que tem parte do seu território dentro do Arco do Desflorestamento. Esse Arco é a parte da região Amazônica onde está concentrada a maior parte do desmatamento e se estende do Maranhão até Rondônia.

Segue Mapa 1 que mostra a região do arco do desflorestamento e o desmatamento na Amazônia Legal. 


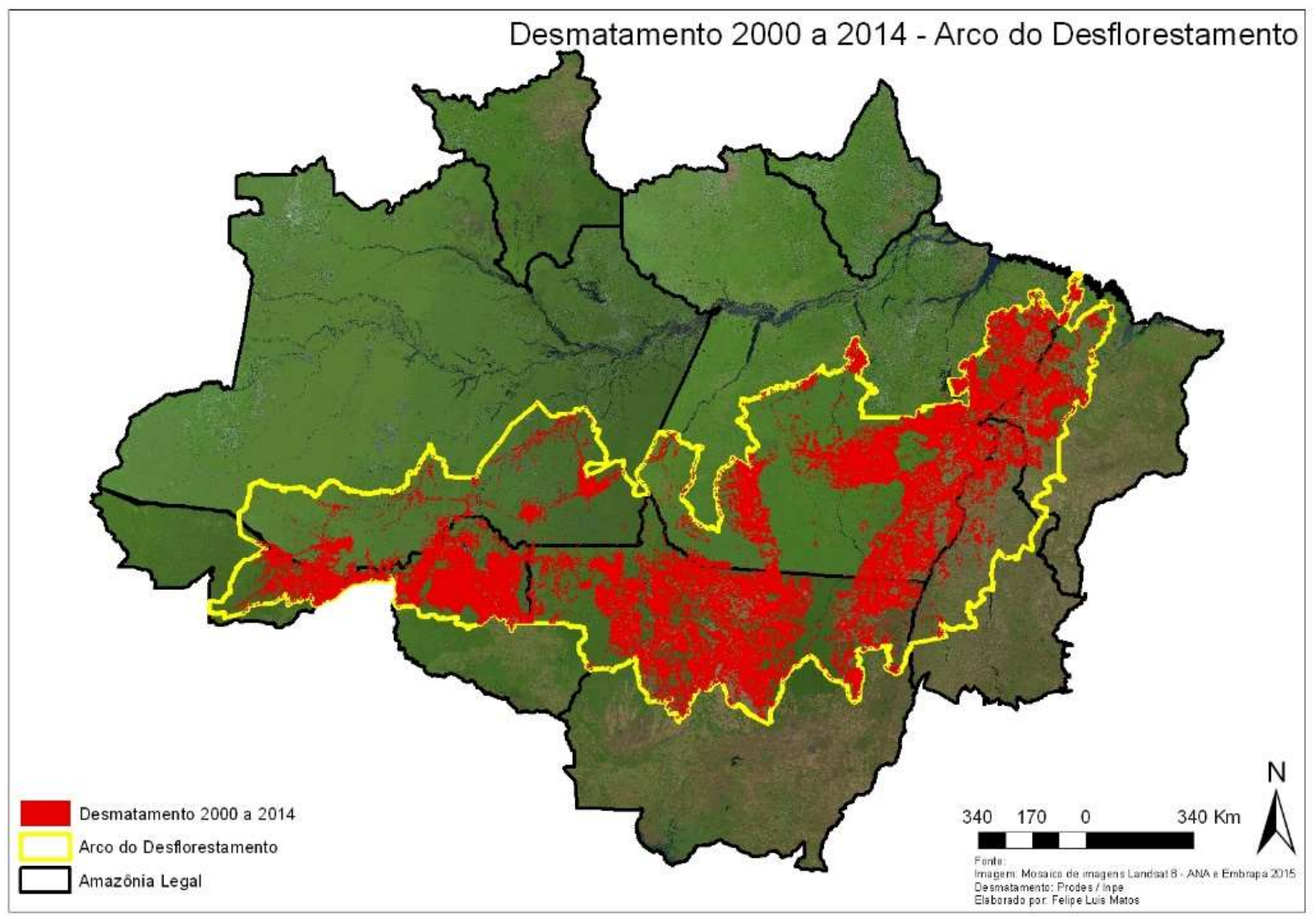

Mapa 1: Desmatamento na região do Arco do Desflorestamento. 
A hipótese a ser trabalhada na pesquisa é de que, quanto maior for a quantidade de autos de infração, maior será a queda nas taxas de desmatamento, ou seja, as medidas de monitoramento e controle tem relação e importância na queda ocorrida nos últimos anos nos índices oficiais de desmatamento.

A observação na investigação científica não se dá de maneira indiscriminada. O pesquisador não realiza uma coleta de dados ao sabor do acaso. Em muitos sentidos, o seu comportamento é previamente delimitado pela hipótese, ou seja, pelo problema que se propõe estudar e que deve ser definido, tanto quanto possível, antes do processo de observação (Silva, 1978, p.78). 


\section{Referencial Teórico}

\subsection{Bioma Amazônico}

\subsubsection{Caracterização do Bioma}

A região norte da América do Sul abriga um dos biomas mais ricos em diversidade biológica do mundo: a Floresta Amazônica. A Amazônia ocupa um lugar de destaque no cenário internacional e sua importância é reconhecida mundialmente. Isso se deve principalmente à sua larga extensão territorial e enorme diversidade de ambiente, com 53 ecossistemas (Sayres et al.,2008 in: ARPA Biodiversidade, 2011, p.3) e mais de 600 tipos diferentes de habitat terrestre e de água doce, o que resulta numa riquíssima biodiversidade, com cerca de 45 mil espécies de plantas e animais vertebrados (ARPA Biodiversidade, 2011, p.3). Cerca de 10\% de toda a diversidade do planeta está localizada na região, inclusive muitas espécies ameaçadas de extinção e também espécies que ocorrem exclusivamente na Amazônia. (Hudson et al., 2000 in: ARPA Biodiversidade, 2011, p.3).

No total ela abrange nove países incluindo o Brasil que abriga cerca de $60 \%$ da área dessa floresta. No Brasil, para fins administrativos e de planejamento econômico, foi instituída a chamada “Amazônia Legal” que engloba os seguintes Estados brasileiros: Amazonas, Pará, Acre, Amapá, Roraima, Rondônia, Tocantins, em sua totalidade e parte dos Estados do Maranhão e Mato Grosso.

Segue o Mapa 2 que mostra os Estados que compõem a Amazônia Legal. 


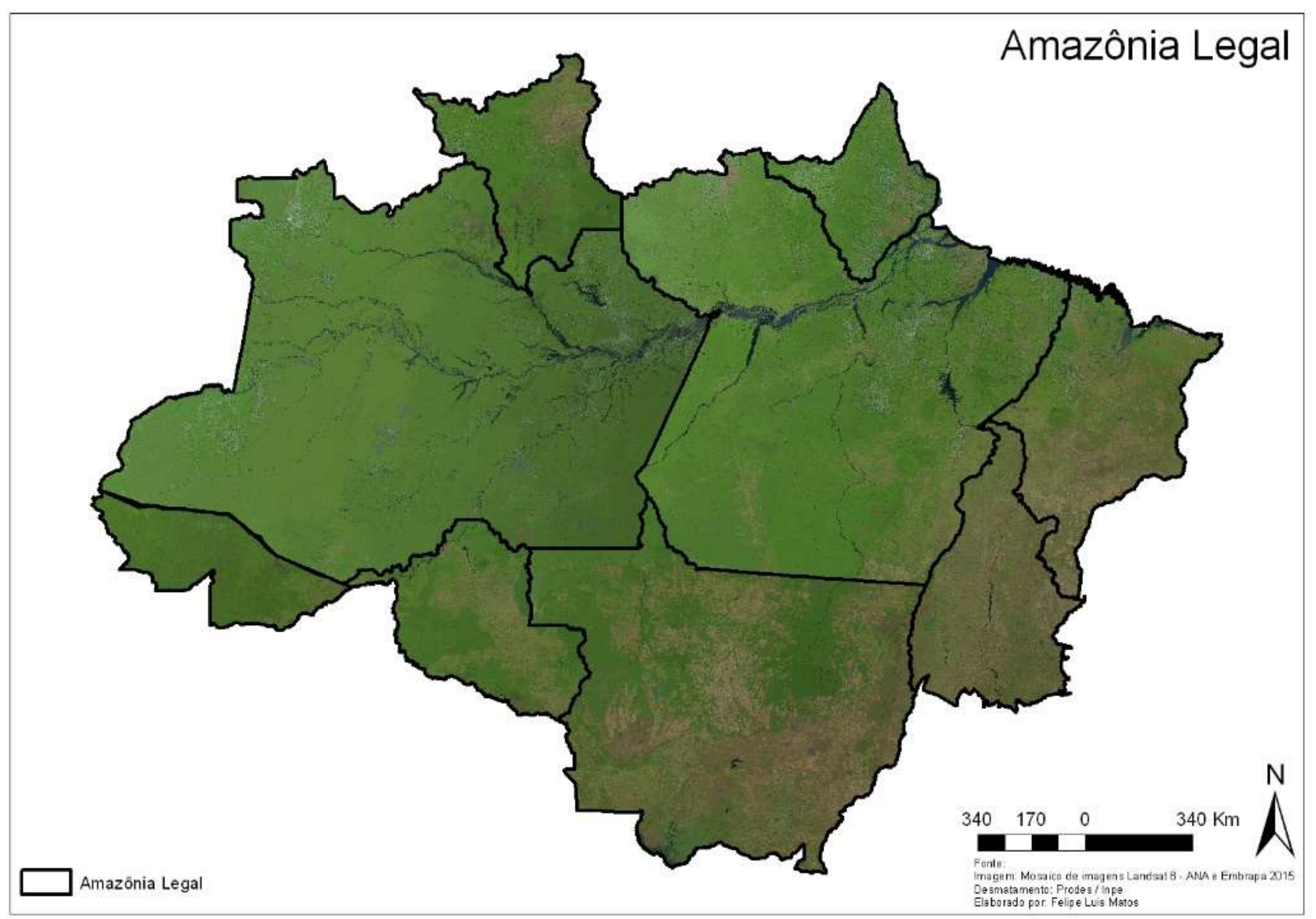

Mapa 2: Mapa da Amazônia Legal. 


\subsubsection{Ocupação Territorial do Bioma na segunda metade do século XX}

A fase recente da ocupação da bacia amazônica começou na década de 60 do século XX com a construção de estradas ligando o Centro-Sul à região Norte (Alencar et. al., 2004, p.12).

Em 1964 os militares assumiram o governo brasileiro e estabeleceram uma nova dimensão ideológica, segundo a qual a região amazônica representava um vazio demográfico que deveria ser ocupado a qualquer custo (Lui, 2009, p.219).

Nas décadas de 70 e 80, o desmatamento foi um reflexo do modelo desenvolvimentista e de integração pensado para a região, pautado por políticas de ocupação (por motivos geopolíticos) concretizados por meio da implantação de grandes projetos de colonização e mineração. Os incentivos fiscais para os grandes projetos agropecuários tiveram também papel importante, viabilizando a conversão de grandes áreas florestais em pastagens extensivas (Alencar et. al., 2004, p.12).

Desconsiderando toda a história de ocupação humana precedente, o governo militar deu início aos grandes projetos de colonização e desenvolvimento da Amazônia, como o Programa de Integração Nacional (1970), o programa Polo Amazônia (1974), o programa Grande Carajás (1980) e o Programa Polo Noroeste (1983). Esses grandes programas institucionais tinham como objetivos principais o incentivo às atividades econômicas e à colonização de grandes extensões de terra (Lui, 2009, p.219).

Para atingir o primeiro objetivo, o governo investiu bilhões de dólares na construção de infraestrutura na forma de portos, aeroportos e, principalmente, na construção de estradas que atravessariam a floresta, como a Cuiabá-Porto Velho (BR 364 em 1968), a Transamazônica (BR 230 em 1972) e a Cuiabá-Santarém (BR 163 em 1973), além de milhares de quilômetros de estradas secundárias para incrementar o potencial de exploração e ocupação da floresta. Além disso, concedeu incentivos fiscais e criou mecanismos legais para transferência de terra para grandes produtores e empresas, para que essas se motivassem a iniciar suas atividades produtivas na Amazônia (Lui, 2009, p.219).

Para atingir o segundo objetivo, o governo estimulou a chegada de camponeses do Nordeste e do Sul do Brasil para ocupar lotes determinados ao longo das estradas. Para organizar essas atividades, criou em 1970 o Instituto Nacional de Colonização e Reforma Agrária (INCRA), que somente entre 1970 e 1974 enviou cerca de 400.000 colonos para a Amazônia (Lui, 2009, p.220). 
Essas centenas de milhares de pessoas foram atraídas para a região sem o conhecimento prévio de práticas agrícolas adequadas a um ambiente de floresta tropical. Como seria previsível, grande parte dos agricultores fracassou devido à baixa fertilidade das terras e à carência de serviços básicos, como a possibilidade de comercialização da produção, a falta de extensão rural e a ausência de infraestrutura (Lui, 2009, p.220).

Em um primeiro momento, os esforços para a colonização da Amazônia foram direcionados para os pequenos fazendeiros e para a prática da agricultura familiar, a partir de pressões econômicas e demográficas esse processo foi se alterando e grandes fazendas voltadas para a pecuária e para a exportação passarem a ter grande importância na dinâmica do desmatamento (Godar, Tizado, Pokorny, 2012, p.58).

A distribuição espacial das estradas e dos programas de colonização também se coloca como uma variável determinante em relação aos processos de transformação das paisagens amazônicas. Além de permitirem o acesso e a colonização da floresta, as estradas possuem um papel fundamental ao permitirem também o escoamento da produção. A construção e a distribuição das estradas reduzem o custo do transporte, aumentam a rentabilidade e potencializam o próprio desenvolvimento das atividades econômicas. Considerando as principais atividades produtivas que foram incentivadas na região a partir da década de 70 , a opção por esse modelo de transportes se constitui em uma das importantes variáveis que levaram ao avanço do desmatamento (Lui, 2009, p.220).

A ocupação intensa da Amazônia começou no início da década de 70. Embora áreas extensas ainda permaneçam intactas, a taxa de perda da floresta é dramática, em especial no "arco do desmatamento", ao longo das bordas sul e leste. A perda da biodiversidade e os impactos climáticos são as maiores preocupações. A vastidão das florestas remanescentes significa que os impactos potenciais do desmatamento de forma continuada são muito mais importantes que os já severos impactos que ocorreram até hoje (Fearnside, 2005, p.114).

Iniciados na metade dos anos 90, os investimentos em infraestrutura pelos governos federal e estadual foram direcionados principalmente à pavimentação das estradas existentes, ao desenvolvimento de portos e à construção de um gasoduto. As demandas do mercado e esses investimentos resultaram no aumento das atividades humanas na Amazônia brasileira (Barreto, 2005, p.25).

No fim da década de 90 e início dos anos 2000, a Amazônia se encontrava em uma segunda fase de ocupação, na qual os incentivos fiscais têm um papel reduzido e a rentabilidade de atividades extrativistas (extração madeireira) e agropecuárias está impulsionando a expansão e a transformação da fronteira (Alencar et. al., 2004, p.12). 


\subsection{Desmatamento}

O desmatamento pode ser entendido como um corte raso da floresta, diferente do desflorestamento, que envolve ainda a fragmentação e a degradação (Gazoni, et al. 2010, p.26).

O desmatamento faz parte de um conjunto de fenômenos, tais como a multiplicação e o crescimento das cidades, a emergência ou o desaparecimento de atores sociais, as mutações do papel do Estado, a globalização da economia e as recomposições sociais. A aceleração dos processos sociais, tanto quanto os naturais, que caracteriza nossa época, é uma das razões que justificam a urgência da avaliação do impacto da ação humana sobre o ecossistema florestal (Pasquis, et al. 2002, p.284).

Embora a maior parte dos trabalhos sobre o desmatamento leva a crer que ele ocorre apenas em áreas cobertas com floresta densa, isto não é a realidade (Prates, 2008, p.09).

O desmatamento abrange vários tipos de formação vegetal, como as derrubadas de florestas densas e as derrubadas de vegetação secundária, as quais assumem várias modalidades, dependendo do tempo de regeneração. Elas são: capoeirão, que é a vegetação secundária com mais de dez anos da última derrubada; capoeira, a vegetação secundária entre quatro e dez anos; capoeirinha, a vegetação secundária entre dois e quatro anos; e a juquira, que é a vegetação secundária com até dois anos (Homma, 1996, p.17).

O processo de desmatamento por corte raso é aquele que resulta na remoção completa da cobertura florestal em um curto intervalo de tempo. Nesse processo, a cobertura florestal é totalmente removida e substituída por outras coberturas e usos (cultura agrícola, pastagem, área urbana, hidroelétricas, etc.) (INPE, 2013 p.03).

O processo normalmente se inicia antes ou durante o período chuvoso que precede o corte de fato da floresta com o que é localmente denominado de "brocagem". É o corte com foiceou machado das árvores menores e, principalmente, das lianas (cipós), para facilitar o corte das árvores de maior porte que se dará na próxima fase (INPE, 2013 p.03).

\subsubsection{Causas do Desmatamento}

Podem ser consideradas como causas diretas do desmatamento: a expansão das pastagens e áreas agrícolas, extração de madeira e expansão da infraestrutura (Rivero et al. 2009, p.43). 
Vastas áreas florestais da Amazônia vêm sendo convertidas para uso da agricultura, da pecuária, da extração indiscriminada de madeira, entre outras atividades produtivas, resultando em danos, muitas vezes, irreparáveis (Gazoni, Mota, 2010, p.26).

Grandes projetos de infraestrutura e a especulação sobre a terra nas proximidades das rodovias que serão / foram construídas tem impacto direto e contribuem consideravelmente para o aumento dos índices de desmatamento (Laurance et. al., 2004, p.1109).

Inicialmente, o desmatamento é considerado a força motriz para o crescimento econômico e, quando o nível de renda aumenta, os indivíduos tendem a demandar mais das amenidades e benefícios associados às florestas naturais. Assim, quando os indivíduos elevam seu bem-estar, atinge - se um estágio onde a demanda por tais amenidades excede o desejo de permitir o desmatamento para o desenvolvimento econômico (Arraes, et. al., 2012, p.122).

Essa situação ainda não ocorre em todas as regiões do Brasil, principalmente nos principais polos desmatadores existentes no País.

As principais causas do desmatamento da Floresta Amazônica são devidas a atividades econômicas que tem, como necessidade, a derrubada da floresta para que se desenvolvam. Projetos de infraestrutura, expansão da fronteira agrícola e incentivo a ocupação territorial da área são os principais fatores que levam ao desmatamento.

Deve - se tentar conciliar o desenvolvimento dessa região com a devastação em pequena escala do ecossistema local. É difícil a preservação total da área, mas é possível que se tente fazer uma utilização dos recursos naturais gerando menos danos ao meio ambiente.

Os atores e forças que conduzem ao desmatamento variam entre partes diferentes da região e variam ao longo do tempo. Em geral, os grandes e médios fazendeiros respondem pela grande maioria da atividade do desmatamento, mas os pequenos agricultores podem atuar como força importante nos lugares onde estão concentrados (Fearnside, 2006, p.396). O processo de desmatamento é causado por diferentes fatores dependendo do local de ocorrência e do período em que ocorreu / ocorre (Ewers, et. al., 2006, p.203).

Com relação às causas dos desmatamentos nós podemos associá - las a variáveis como proximidade de estradas, preço dos produtos agropecuários, disponibilidade de crédito, e também ao crescimento populacional (este último nem sempre verdadeiro). No entanto, não existe apenas uma variável chave ou um único processo capaz de explicar a dinâmica dos desmatamentos na Amazônia. Isto pode parecer um tanto frustrante, mas é facilmente compreensível quando pensamos na dimensão da região e na escala em que se dão os desmatamentos (Margulis, 2003, p.03). 


\subsubsection{Consequências do Desmatamento}

Mesmo que ainda seja difícil avaliar com precisão o ritmo atual de desaparecimento das florestas, existe hoje o consenso de que ultrapassou em muito as evoluções naturais dos últimos milênios. Conforme as estimativas - muito variáveis - dos especialistas, entre 10 e 17 milhões de hectares desapareceriam a cada ano, e em 2010, a cobertura florestal do planeta não passaria de $60 \%$ da sua superfície de 1990 (Pasquis, et. al., 2002, p. 280).

Além disso, reconhece-se hoje, no mundo inteiro, que o desflorestamento está na origem da maciça extinção de numerosas espécies vegetais e animais (Pasquis, et. al., 2002, p. 280).

O desmatamento envolve realidades diversas, com impactos que variam conforme os meios. Cabe levar em conta não apenas os tipos de desflorestamento, desde aquele entendido como o desaparecimento total da floresta de modo linear e em grandes superfícies até a fragmentação e a degradação da estrutura da floresta, provocadas pela extração seletiva de suas essências (Pasquis, et. al., 2002, p. 282-283).

Para qualquer avaliação de impacto como o do desflorestamento, tudo depende de patamares e escalas. É preciso distinguir entre efeitos globais e locais, mesmo que os dois sejam, provavelmente, relacionados (Pasquis, et. al., 2002, p. 283).

A Floresta Amazônica não pode ser tratada sem um permanente vaivém entre os níveis local, regional e global. Sua homogeneidade é apenas aparente. Na verdade, trata - se de um complexíssimo mosaico de formações naturais. As escalas de tempo também devem ser levadas em conta: é preciso distinguir entre os processos milenares das mudanças climáticas e das pulsações naturais da floresta e as atuais crises extremamente rápidas (fronteiras agrícolas, migrações dirigidas ou espontâneas, construção de estradas e barragens hidrelétricas, etc.), passando pelas evoluções históricas ou os "milagres econômicos" característicos das regiões florestais tropicais que marcaram os últimos séculos (Pasquis, et. al., 2002, p. 283).

A aceleração dos processos sociais, tanto quanto os naturais, que caracterizam nossa época, é uma das razões que justificam a urgência da avaliação do impacto da ação humana sobre o ecossistema florestal. (Pasquis, et. al., 2002, p. 283)

Segundo o IBGE, cerca de $20 \%$ da cobertura original da floresta amazônica brasileira já está desmatada.

Os desmates ocorreram com maior intensidade no denominado Arco do Desmatamento, uma extensa região que cobre a porção leste, sudeste e sul da Amazônia, entre os Estados do Pará, Mato 
Grosso e Rondônia. O resultado desse processo de ocupação desordenada tem sido bastante nefasto para as espécies de fauna e flora nativas da região (Machado, 2001, p.228).

Apesar da sua aparência luxuriante (biomassa e velocidade de crescimento elevadas), a floresta tropical é frágil. O seu desaparecimento desnuda solos com parcas reservas minerais e estes sofrem uma erosão rápida, o que provoca seu esgotamento e a diminuição da fauna e microfauna, assim como sua transformação sob o efeito do aumento da radiação solar que eleva a temperatura e diminui a umidade. A exploração florestal, mesmo seletiva, também possui um impacto importante, principalmente na superfície do solo (Pasquis, et. al., 2002, p. 288).

Os impactos dos desmatamentos sobre a biodiversidade podem ser agrupados em duas grandes categorias: a perda imediata de habitat natural e a fragmentação. A eliminação dos habitats naturais é a causa primária da extinção local de populações e espécies pois a vegetação natural é substituída por pastagens, áreas de plantio ou áreas urbanas. (Machado, 2001, p.228).

A fragmentação da floresta tem múltiplos efeitos sobre a biota amazônica, podendo alterar a diversidade e a composição das comunidades nos fragmentos e mudar processos ecológicos como a polinização, a ciclagem de nutrientes e o estoque de carbono (Laurance, 2009, p.434).

Em função da alta concentração local de espécies no ecossistema florestal da Amazônia, a eliminação de extensas áreas causa a extinção de organismos que possuem uma pequena área de distribuição. Entretanto, o processo de ocupação na Amazônia foi causado por milhares de colonos que realizam o desmatamento aos poucos e em determinados pontos. Como resultado, alguns trechos de vegetação nativa ficam isolados do maciço florestal sendo formados, dessa maneira, os fragmentos (Machado, 2001, p.228).

O impacto do desflorestamento pode ser direto e indireto: direto, fazendo desaparecer a cobertura florestal, o que provoca transformações importantes do conjunto de elementos do ecossistema (vegetação, solo, fauna, microclima) e indireto, por intermédio do uso posterior da terra (Pasquis, et. al., 2002, p. 287).

\subsubsection{Dinâmica do Desmatamento}

Pelo fato de não existir uma única variável chave para explicar a dinâmica do desmatamento ilegal na Amazônia, o entendimento das peculiaridades de cada região é importante para tentar alcançar uma maior efetividade no trabalho de combate e repressão ao desmatamento ilegal. Conhecer as características locais pode ser uma forma de ter mais qualidade no trabalho. 
A dinâmica dos desmatamentos é diferente entre os estados da Amazônia, que tem suas políticas fundiárias e históricas de ocupação distintas. O processo dos desmatamentos em Rondônia, caracterizado pela ocupação de pequenos colonos, é bastante distinto dos que ocorrem no Pará e no Mato Grosso. É diferente também em relação à localização ao longo do arco do desmatamento, dependendo principalmente do grau de consolidação da fronteira, isto é, da distância aos mercados, da existência de mão de obra e de infraestrutura, particularmente de estradas, da disponibilidade de terras devolutas em relação às privadas e também do tipo de vegetação e, portanto, da existência de madeiras comercializáveis (Margulis, 2003, p.10).

A dinâmica dos desmatamentos é diferente dependendo das distintas políticas fundiárias e históricas de ocupação de cada região. É importante tentar atuar de forma diversa levando em conta as peculiaridades de cada local. Essa pode ser uma maneira de aperfeiçoar o trabalho de combate ao desmatamento ilegal realizado pelo IBAMA e órgãos parceiros.

O desmatamento na Amazônia é fruto da continuidade da tradicional forma de expansão da fronteira agrícola brasileira, que, em geral, costuma ocorrer através das seguintes etapas: a ocupação de terras virgens (privadas ou públicas), a extração de sua madeira de lei, a instalação da pecuária e, por fim, o desenvolvimento de uma agropecuária mais moderna. Essas atividades econômicas exercem o papel de gerar renda e legitimar a ocupação dos novos proprietários no curto prazo, quase sem necessidade de recursos. No longo prazo, as terras ou permanecem com pecuária mais intensiva, ou, se existir demanda, serão convertidas para grãos ou outra atividade econômica (Reydon, 2011, p.145).

\subsubsection{Combate e Controle do Desmatamento}

O combate ao desmatamento no Brasil é uma prioridade para o governo e para as organizações internacionais. O monitoramento e a repressão são, atualmente, as estratégias principais. Uma fiscalização efetiva e a aplicação de multas para aqueles que não possuem autorização do IBAMA, contudo, devem ser acompanhadas pela compreensão necessária dos aspectos sociais, econômicos e políticos para se tratar o problema por meio de mudanças na política (Fearnside, 2005, p.114).

É de fundamental importância entender o que ocorre na realidade de cada região estudada para que as medidas coercitivas sejam tomadas de forma eficiente, ou seja, atacando sempre aqueles que estão na ilegalidade. Dar a oportunidade para que as pessoas trabalhem sempre na legalidade é obrigação do governo federal. 
Como estratégias para desacelerar o desmatamento, podemos citar: repressão, reforma política sobre impostos, créditos e subsídios, título de posse da terra e reforma política do assentamento e serviços ambientais (Fearnside, 2005, p.119-121).

Fazer a repressão baseada apenas na aplicação de multas não é a forma mais eficaz de combater ao desmatamento ilegal. Atualmente a descapitalização do infrator e a tentativa de dificultar o acesso ao crédito agrícola já estão sendo utilizadas, mas ainda não conseguem deter a prática ilegal visto o aumento da taxa que tivemos no último ano.

Aliar a repressão através de multas com medidas restritivas de acesso ao crédito além do embargo às áreas desmatadas ilegalmente é o caminho que vem sendo tomado e que deve ser aperfeiçoado para que as taxas tenham chance de voltar a regredir novamente.

O Estado deve se valer de seu poder de imposição e de regulação, mas também de mecanismos econômicos capazes de interferir em comportamentos individuais (Machado, 2009, p.138).

A implantação de unidades governamentais voltadas para o meio ambiente em municípios que não as possuem, juntamente com políticas direcionadas para o aumento do nível educacional, redução da desigualdade de renda e o cumprimento de leis regulatórias, visando delimitar a expansão desordenada da fronteira agropecuária, são ações imperativas relevantes para, se não conter, arrefecer o desmatamento da Amazônia Brasileira (Arraes, et al. 2012, p.01).

Maior presença de órgãos do governo, negativa de crédito para os desmatadores ilegais e pressão sobre as empresas que compram produtos advindos da floresta podem contribuir para a diminuição das taxas de desmatamento (Nepstad, et.al, 2009, p.1350).

Tão importante quanto a repressão é a criação de formas para que as pessoas e empresas que trabalham no campo possam agir dentro da legalidade. A partir do momento que isso estiver estabelecido o combate certamente será ainda mais eficaz.

Quando você pune o infrator, a degradação já ocorreu, o mais importante e interessante é conseguir evitar que ocorra o incremento de novas áreas e, a partir disso, que ocorra a diminuição também das medidas punitivas e das áreas desmatadas. Evitar a abertura de novas áreas na ilegalidade e a partir desse fato fazer com que a punição seja cada vez menor, pode vir no futuro a ser um sinal de diminuição nas taxas de desmatamento.

O Estado, diante da questão ambiental, manifesta uma situação paradoxal: parte de seu aparelho constitui os principais canais institucionais de defesa da qualidade do meio ambiente, outra parte constitui os principais agentes de degradação (Moraes, 2005, p.57).

A floresta só deixará de ser destruída se tiver valor econômico para competir com a madeira, com a pecuária e com a soja. Mesmo com os grandes avanços na sua proteção, a questão de manter a 
capacidade sustentável da floresta ainda não foi solucionada. Florestas e terras são bens públicos e, por isso, são trunfos que estão sob o poder do Estado, que tem autoridade para dispor deles, segundo o interesse da nação (Becker, 2005, p.85).

Experiências recentes em planejamento regional, zoneamento agroecológico e fiscalização ambiental devem ser refinadas e multiplicadas para que consigamos sobrepujar as crescentes forças de exploração da floresta. Mas somente a presença da lei não basta, pois há, igualmente, necessidade de se valorizar a floresta em pé, buscando economias florestais, calcadas em uma sólida base macroeconômica, que sejam competitivas em face dos usos atuais em áreas convertidas, como a criação de gado e a plantação de grãos. Adiciona - se a essa estratégia, a certificação ambiental para produtos de agricultores e fazendeiros que preservam a floresta em suas propriedades (Soares-Filho, et.all, 2005, 148).

As políticas de controle do desflorestamento somente conseguirão influenciar o comportamento dos atores da região se houver uma ação mais efetiva do Estado, por meio da utilização de mecanismos de regulamentação (Machado, 2009, p.115).

As áreas protegidas, a produção extrativista não madeireira e a proximidade a um escritório regional do IBAMA são aspectos que podem ser entendidos como protetores da floresta contra o desmatamento (Gazoni, et.all, 2010, p.40).

Uma das maneiras mais eficientes para tentar diminuir as taxas de desmatamento é fazer com que as pessoas no campo possam tirar seu sustento sem precisar destruir a cobertura vegetal. Tentar agregar valor econômico ao produto da floresta, buscar tecnologia para produzir mais em áreas que já foram afetadas e não ter sempre que abrir novas áreas para a produção e principalmente modificar o modelo de pecuária extensiva que necessita de grandes extensões de terra para que o gado seja criado. Na atualidade, um dos principais motivos para o desmatamento é a abertura de áreas para a pecuária extensiva.

A compensação financeira para a preservação da floresta pode contribuir para a queda dos índices de desmatamento (Nepstad, et.all, 2009, p.327).

Deve se ter claro que a universidade não é o principal sujeito das transformações sociais e sequer do processo de controle da degradação ambiental. As decisões no setor devem fluir do movimento da prática social, através de seus condutores próprios com os quais a universidade deve estabelecer interfaces (Moraes, 2005, p.62).

Apesar da universidade não ser o principal sujeito do processo de controle da degradação ambiental, ela tem papel fundamental nessa questão ao colocar para o debate os assuntos relacionados a essa temática e ao difundir os argumentos teóricos que possibilitarão um maior aprofundamento 
sobre o tema. Tratar de temas de relevância para toda a sociedade é um dos objetivos que a universidade deve ter e tentando, sempre que possível, aliar a teoria com a prática.

Ao analisar fenômenos sociais, o pesquisador além de sujeito é também parte do objeto (enquanto membro da sociedade), por isso sua avaliação pauta - se muito mais por sua vivência objetiva e pelas concepções que desenvolve em sua vida cotidiana. Os valores culturais e políticos necessariamente se imiscuem na leitura que ele faz de seu objeto. $O$ intervalo entre ciência e ideologia fica assim bem mais impreciso no estudo dos fenômenos sociais (Moraes, 2005, p.77).

Como exemplo real do que o governo fez para melhorar o combate o controle do desmatamento na Amazônia Legal pode - se citar a intensificação das operações de campo nas áreas mais problemáticas.

O governo priorizou as operações de campo contra o desmatamento, tendo, como foco, os 36 principais municípios desmatadores que eram responsáveis por cerca de $50 \%$ do desmatamento na Amazônia. Essas operações começaram em março de 2008 e resultaram em multas, apreensão de equipamentos e bens associados a crimes ambientais e ao embargo das áreas desmatadas ilegalmente (Barreto, 2010, p.10)

Além das operações de campo, foram priorizadas o embargo econômico das áreas desmatadas ilegalmente juntamente com a responsabilização para quem adquirisse produtos provenientes dessas áreas e a restrição de crédito para os proprietários que praticassem ilícitos ambientais (Barreto, 2010. p.11).

\subsection{Políticas Governamentais de Combate ao Desmatamento Ilegal}

\subsubsection{Plano de Ação para a Prevenção e Controle do Desmatamento na Amazônia Legal} (PPCDAM)

O lançamento do PPCDAM introduziu uma nova maneira de combater o desmatamento na Amazônia Legal. A partir dele, os esforços de conservação apoiaram-se em uma extensa série de medidas estratégicas, a ser implementadas como parte de um esforço conjunto dos governos federal, estadual e municipal, junto a organizações especializadas e a sociedade civil. A colaboração mútua entre os diferentes níveis e órgãos governamentais aumentou a intensidade das atividades de monitoramento (Assunção, et. al. 2012, p.02).

Através do Decreto s/nº de 03 de julho de 2003, foi criado o Grupo Permanente de Trabalho Interministerial que tinha como prioridade a viabilização de um novo modelo de desenvolvimento na 
região amazônica, baseado na inclusão social com respeito à diversidade cultural, a viabilização de atividades econômicas dinâmicas e competitivas e o uso sustentável dos recursos naturais, mantendo o equilíbrio ecológico desse enorme patrimônio brasileiro (PPCDAM, 2004, p.07).

O programa se divide em 3 fases. A primeira fase, do ano de 2004 a 2008, a segunda fase, de 2009 a 2011, e a terceira fase, de 2012 a 2015.

$\mathrm{Na}$ primeira fase do programa, foram definidas as diretrizes estratégicas e as estratégias de implementação do plano.

Ele tinha a finalidade de propor medidas e coordenar ações que tinham como objetivo reduzir os índices de desmatamento na Amazônia Legal, por meio dos seguintes instrumentos: i) ordenamento fundiário nos municípios que compõem o Arco do Desmatamento, ii) incentivos fiscais e creditícios com os objetivos de aumentar a eficiência econômica e a sustentabilidade de áreas já desmatadas, iii) procedimentos para a implantação de obras de infraestrutura ambientalmente sustentáveis, iv) geração de emprego e renda em atividades de recuperação de áreas degradadas, v) incorporação ao processo produtivo de áreas abertas e abandonadas e manejo de áreas florestais, vi) atuação integrada dos órgãos federais responsáveis pelo monitoramento e a fiscalização de atividades ilegais no Arco do Desmatamento e vii) outros que julgar pertinentes (PPCDAM, 2004, p.07).

O grupo tinha a coordenação da Casa Civil da Presidência da República e era composto pelos seguintes órgãos do Governo Federal: i) Ministério da Agricultura, Pecuária e Abastecimento (MAPA), ii) Ministério da Ciência e Tecnologia (MCT), iii) Ministério da Defesa (MD), iv) Ministério do Desenvolvimento Agrário (MDA), v) Ministério do Desenvolvimento Indústria e Comércio Exterior (MDIC), vi) Ministério da Integração Nacional (MI), vii) Ministério da Justiça, viii) Ministério do Meio Ambiente (MMA), ix) Ministério das Minas e Energia (MME), x) Ministério dos Transportes (MT), e xi) Ministério do Trabalho e Emprego (MTE). A partir de decreto assinado em 15 de março de 2004, passaram a integrar o grupo o Ministério do Planejamento, Orçamento e Gestão e o Ministério das Relações Exteriores (PPCDAM, 2004, p.07). 
Foram criados 4 subgrupos de trabalhos para a elaboração de propostas estratégicas. Os 4 subgrupos, seus membros e suas áreas de atuação são as seguintes:

\begin{tabular}{|l|l|l|}
\hline \multicolumn{1}{|c|}{ Sub-Grupo } & \multicolumn{1}{|c|}{ Membros } & \multicolumn{1}{|c|}{ Área de Atuação } \\
\hline $\begin{array}{l}\text { 1) Ordenamento Fundiário e } \\
\text { Territorial }\end{array}$ & $\begin{array}{l}\text { SDS/MMA (coord), SCA/MMA, } \\
\text { MDA, MAPA, MI, MDIC, MD, } \\
\text { MJ/FUNAI. }\end{array}$ & $\begin{array}{l}\text { - Instrumentos de ordenamento territorial com } \\
\text { enfoque para política fundiária, unidades de } \\
\text { conservação e estratégias de desenvolvimento } \\
\text { local sustentável. }\end{array}$ \\
\hline 2) Monitoramento e Controle & $\begin{array}{l}\text { IBAMA/MMA (coord), SCA/MMA, } \\
\text { MCT, MD, MJ, TEM, SIPAM/Casa } \\
\text { Civil. Instrumentos de Monitoramento, } \\
\text { licenciamento e fiscalização de } \\
\text { desmatamento, queimadas e exploração } \\
\text { madeireira. }\end{array}$ \\
\hline 3) Fomento a Atividades Produtivas & $\begin{array}{l}\text { SBF/MMA (coord), SCA/MMA, } \\
\text { Sustentáveis }\end{array}$ & $\begin{array}{l}\text { - Crédito Rural e Incentivos Fiscais. } \\
\text { - Assistência Técnica e Extensão Rural. } \\
\text { - Pesquisa Científica e Tecnológica }\end{array}$ \\
\hline 4) Infraestrutura & $\begin{array}{l}\text { SCA/MMA, MF (convidado) } \\
\text { MAPA, MI, MDIC }\end{array}$ & $\begin{array}{l}\text { - Políticas de infraestrutura, com enfoque para } \\
\text { os setores de transporte e energia. }\end{array}$ \\
\hline
\end{tabular}

Tabela 2: Organograma de trabalho PPCDAM. Fonte: PPCDAM, 2004, p.08

A partir da consolidação das propostas dos quatro subgrupos, o PPCDAM apresenta em conjunto de ações estratégicas, consideradas prioritárias por sua relevância para a contenção do desmatamento na Amazônia Legal bem como para a viabilização de estratégias alternativas de proteção e uso sustentável da floresta. O PPCDAM inclui medidas emergenciais, com potencial de gerar impactos no curto prazo e outras ações prioritárias que demandam prazos maiores para gerar impactos efetivos, mas que devem ser iniciadas imediatamente, por sua relevância na estruturação de soluções duradouras (PPCDAM, 2004, p.08).

As diretrizes estratégicas do PPCDAM foram: valorização da floresta para fins de conservação da biodiversidade, manejo florestal de produtos madeireiros e não-madeireiros e a prestação de serviços ambientais; incentivos para a melhor utilização de áreas já desmatadas em bases sustentáveis contemplando inovações tecnológicas com o objetivo de diminuir a pressão sobre florestas remanescentes; tomada de medidas de ordenamento fundiário e territorial; aprimoramento dos instrumentos de monitoramento, licenciamento e fiscalização do desmatamento; fortalecimento de uma cultura de planejamento estratégico de obras de infraestrutura, envolvendo a análise adequada de alternativas, medidas preventivas, mitigadoras e compensatórias; fomento à cooperação entre instituições do governo federal, responsáveis pelo conjunto de políticas relacionadas às dinâmicas de desmatamento na Amazônia Legal; adoção de um estilo de gestão descentralizada e compartilhada de políticas públicas, por meio de parcerias entre a União, estados e municípios; estímulo a participação ativa dos diferentes setores interessados da sociedade amazônica na gestão das políticas 
relacionadas à prevenção e controle do desmatamento; valorização da aprendizagem entre experiências piloto bem sucedidas e a efetivação de um sistema de monitoramento das dinâmicas do desmatamento e políticas públicas correlatas na Amazônia (PPCDAM, 2004, p.18).

Os principais resultados da primeira fase do PPCDAM, no período de 2004 a 2008 foram os seguintes: criação de mais de 25 milhões de hectares de unidades de conservação, em geral, localizadas nas áreas de conflito; homologação de mais de 10 milhões de hectares em terras indígenas; inibição de mais de 60 mil títulos de imóveis rurais; criação do sistema DETER, que indica alertas de desmatamento e aperfeiçoamento do sistema PRODES, que mede a taxa; nova metodologia de fiscalização do IBAMA, com o planejamento das operações em áreas prioritárias e a participação do Exército, da Polícia Federal e Polícia Rodoviária Federal, resultando na apreensão expressiva de volumes de madeira em tora e de equipamentos e aplicação de multas; combate à corrupção com a prisão de mais de 600 servidores públicos que praticaram crime contra o meio ambiente e a ordem pública; Lei de Gestão de Florestas Públicas (Lei 11.824/06), que dá transparência à identificação das florestas públicas e agiliza o processo de concessão florestal; implantação do Serviço Florestal Brasileiro, Criação do Distrito Sustentável da BR-163 e a $1^{\text {a }}$ licitação pública de concessão florestal (Flona Jamari -RO) (PPCDAM, 2009, p.10)

No segundo semestre do ano de 2007, ainda no decorrer da primeira fase do PPCDAM, os alertas mensais emitidos pelo Sistema DETER, do INPE, começaram a apontar uma retomada do aumento nas taxas de desmatamento. Esse fato fez com que o governo lançasse o decreto $6321 \mathrm{em}$ 21 de dezembro de 2007 que estabelecia um conjunto de medidas voltadas para o controle do desmatamento, entre elas destacam - se a edição da lista de municípios considerados prioritários para as ações de controle ambiental e fundiário, nos quais ficava proibida a emissão de novas autorizações de desmatamento, a possibilidade do INCRA promover o recadastramento dos imóveis rurais e a obrigatoriedade do embargo de áreas ilegalmente desmatadas. (PPCDAM, 2009, p.11)

Ocorreu também, em julho de 2008, com a edição do decreto 6514, a atualização e aprimoração da Lei de Crimes Ambientais. Além disso, o Conselho Monetário Nacional (CMN), por meio da resolução n $^{\circ} 3545$ de 29 de fevereiro de 2008, aceitou alterar as regras do crédito rural para exigir, pela primeira vez, o requisito de regularidade ambiental e fundiária para a concessão de empréstimo a propriedade rurais dentro da Amazônia (PPCDAM, 2009, p.11).

$\mathrm{Na}$ segunda fase do PPCDAM, o objetivo era promover a queda contínua das taxas de desmatamento na Amazônia brasileira, em direção ao desmatamento ilegal zero, por meio de um conjunto de ações integradas de ordenamento territorial e fundiário, monitoramento e controle, fomento a atividades produtivas sustentáveis, envolvendo parcerias entre o setor púbico federal, os 
estados, as prefeituras, as entidades da sociedade civil organizada e o setor privado (PPCDAM, 2009, p.58).

Os impactos esperados para o período de 2009-2011 são: queda contínua da taxa de desmatamento na Amazônia brasileira, especialmente em termos de práticas ilegais que geram significativos danos ambientais e problemas sociais; diminuição substancial nas práticas de grilagem de terras públicas em áreas críticas, associadas ao desmatamento ilegal; redução acentuada nos índices de exploração madeireira ilegal, associada a um crescimento expressivo na área sob manejo florestal para produtos madeireiros e não-madeireiros; forte aumento na adoção de práticas de prevenção e controle do fogo, recuperação de áreas degradadas, manejo de pastagens e práticas agropecuárias e agroflorestais sustentáveis entre produtores rurais; redução significativa no percentual de propriedades com passivo ambiental referente à Reserva Legal e Áreas de Preservação Permanente, associado a um aumento nos casos de celebração de Termos de Ajustamento de Conduta e práticas de recuperação de áreas degradadas; avanços na viabilização de um novo modelo de reforma agrária em bases sustentáveis para a Amazônia brasileira com significativas implicações para a redução do desmatamento; avanços substanciais na criação e implantação de unidades de conservação e terras indígenas em áreas prioritárias, como elementos fundamentais de uma estratégia de conservação da floresta e o desenvolvimento sustentável da Amazônia; e aumento significativo na capacidade institucional de órgãos ambientais e outras instituições parceiras, inclusive da sociedade civil, na implementação integrada de medidas de prevenção e controle do desmatamento e na viabilização e fomento de atividades produtivas sustentáveis (PPCDAM, 2009, p.58-59).

Os principais resultados da segunda fase do PPCDAM, no período de 2009 a 2011, foram os seguintes: demarcação e sinalização do perímetro de Unidades de Conservação na área de influência da BR-319; elaboração do Macro Zoneamento Ecológico Econômico da Amazônia Legal; georreferenciamento de 25.618 posses rurais no âmbito do Programa Terra Legal; realização de 649 operações de fiscalização integradas em áreas prioritárias, totalizando 7,2 bilhões em multas aplicadas, 864mil m³ de madeiras apreendidas e cerca de 600 mil hectares de áreas embargadas; Formação de 50 guardas-parque para a proteção das unidades de conservação da Amazônia Legal; Realização de auditoria nos sistemas digitais de controle de produtos florestais de 5 Estados da Amazônia Legal; criação e implementação de núcleo central para coordenação de ações de investigação dos ilícitos ambientais; restrição de crédito público a empreendimentos ligados ao desmatamento ilegal (Resolução BACEN no 3545/2008); implementação da Operação Arco Verde, por meio de alternativas produtivas sustentáveis e apoio à regularização ambiental dos imóveis rurais; Concessão de aproximadamente 49.000 hectares de Florestas Públicas para Manejo Florestal 
Sustentável; aperfeiçoamento dos instrumentos de financiamento e crédito para conservação ambiental e conservação das florestas; instituição de pactos setoriais com o setor empresarial, visando a redução do desmatamento e a responsabilidade socioambiental das cadeias produtivas (Moratória da Soja, Madeira Legal); 533 licenças ambientais protocoladas para assentamentos de reforma agrária na Amazônia Legal nos respectivos órgãos estaduais de meio ambiente; 13.582 famílias atendidas em projetos de manejo de recursos naturais em assentamentos, visando à recuperação das Áreas de Preservação Permanente e Reserva Legal, além da adoção de práticas produtivas sustentáveis; Apoio da Política de Garantia de Preços Mínimos da Sociobiodiversidade (PGPM-BIO) de 2009 a junho de 2011 aos produtos borracha, babaçu, castanha do Brasil e fibra de piaçava - totalizando uma subvenção de R\$ 5.163.674,10 e 23.739 extrativistas beneficiados (PPCDAM, 2013, p.23-24).

Os impactos esperados para o período de 2012-2015 são: diminuição da disputa de terras, combatendo a grilagem de terras e à violência no campo; melhoria de governança dos órgãos fundiários; promoção do uso e a ocupação do território de forma ordenada, compatibilizando o desenvolvimento socioeconômico com a proteção ambiental; maior estruturação e presença dos órgãos federais ne gestão de unidades de conservação federais e terras indígenas na Amazônia; melhor estruturação dos órgãos federais de comando e controle; Melhorias tecnológicas nos sistemas de monitoramento da cobertura florestal; detecção de desmatamento na presença de nuvens; implementação de estrutura logística mínima para uso nas ações de comando e controle; efetiva implementação de ações de comando e controle nos Plano de Prevenção e Controle do Desmatamento dos Estados da Amazônia Legal; integração e melhorias dos bancos de dados de gestão estaduais e federais; melhor estruturação de OEMAs e Polícias Estaduais no interior da Amazônia; aumento da presença do poder de estados no interior da Amazônia; cadastramento ambiental rural (CAR) implementado nos municípios prioritários do PPCDAM; avanço no modelo de desenvolvimento sustentável na região amazônica, com erradicação da pobreza, a segurança alimentar e nutricional, a conservação da biodiversidade e a geração de trabalho e renda; fomento à estruturação de uma economia de baixo carbono e com o uso sustentável e eficiente dos recursos naturais; intensificação do uso do solo e maior eficiência no uso dos recursos naturais por meio de atividades sustentáveis, economicamente rentáveis e de baixo impacto ambiental; redução do desmatamento através da fixação e intensificação da agropecuária em áreas já desmatadas e expansão dos mecanismos institucionais de aquisição de alimentos como o PAA, como instrumento de inclusão produtiva sustentável (PPCDAM, 2013, p.85,92,172). 


\subsubsection{Resultados do Plano de Ação para a Prevenção e Controle do Desmatamento na}

Amazônia Legal (PPCDAM)

A queda do desmatamento após o lançamento e início de implantação do PPCDAM no período de 2005 a 2007 foi resultado de vários fatores que ocasionaram a diminuição da demanda por novos desmatamentos, entre eles, o aumento do risco de punição para as pessoas envolvidas com este tipo de ilícito ambiental, a criação da lista de áreas embargadas e a imposição de penalidades para quem negociasse produtos oriundos de áreas embargadas, a moratória da soja e a expansão de novas áreas de proteção (Nepstad, 2014, p.1120).

Estudos mostram que a criação de novas áreas de proteção integral foi mais eficaz para evitar o desmatamento do que as áreas de uso sustentável, independentemente do nível de pressão que elas sofrem (Nolte, 2013, p.4958).

Entre 2000 e 2005, ocorreu a criação de áreas de proteção integral em locais com alta pressão de desmatamento. A criação de novas áreas de proteção integral teve grande importância para a diminuição nas taxas de desmatamento (Nolte, 2013, p.4959).

A notável diminuição dos índices de desmatamento no Brasil fornece importantes lições sobre a importância da criação de políticas públicas, do fortalecimento dos sistemas de monitoramento e da intervenção na cadeia produtiva com o intuito de dificultar o trabalho daqueles que insistem em praticar ilícitos (Nepstad, 2014, p.1120).

Vale a pena destacar o embargo de propriedades privadas onde existisse a ocorrência de desmatamentos ilegais e a intensificação das operações de fiscalização em municípios com taxas de desmatamento elevadas (Arima, 2014, p.467).

Como exemplo prático do fortalecimento da utilização dos sistemas de monitoramento produzidos a partir das informações obtidas através da análise e interpretação das imagens de satélite, temos o seguinte caso.

Em 2004, o IBAMA começou a utilizar o DETER (Sistema de detecção de desmatamento em Tempo Real) produzido pelo INPE (Instituto Brasileiro de Pesquisas Espaciais), para reestruturar e aprimorar suas ações em campo (Arima, 2014, p.466).

A continuação da redução dos desmatamentos ilegais dependerá da percepção do risco de punição para as pessoas que cometem esse ilícito (Nepstad, 2014, p.1121).

O declínio nas taxas de desmatamento após o ano de 2008 é provável que seja devido em grande parte às políticas adotadas e não apenas a período de baixa na economia. Deve - se tentar 
entender as circunstâncias que levaram o Estado e a sociedade civil a trabalhar em conjunto para exigir, decretar e fiscalizar as políticas ambientais de maneira mais rigorosa (Arima, 2014, p.471).

\subsection{Auto de Infração}

O auto de infração é o documento que abre o processo administrativo destinado à apuração da existência, ou não, da infração ambiental.

As infrações ambientais são apuradas mediante processo administrativo específico, no qual é assegurado, ao acusado, o Direito Constitucional da Ampla Defesa e do Contraditório. Portanto, deve, obrigatoriamente, ser formal e preencher requisitos previstos na norma ambiental aplicável.

Diz o artigo 70 da Lei 9.605/98, Lei dos Crimes Ambientais ou LCA, que a infração administrativa ambiental é toda ação ou omissão que viole as regras jurídicas de uso, gozo, promoção, proteção e recuperação do meio ambiente.

O auto de infração ambiental e posterior instauração de processo administrativo constituem atos de competência dos funcionários de órgãos integrantes do Sistema Nacional do Meio Ambiente - SISNAMA, desde que designados para as atividades de fiscalização, sendo que também são igualmente competentes os agentes da Capitania dos Portos, do Ministério da Marinha, sob pena de corresponsabilidade.

Uma vez que a Constituição Federal em seu artigo 225 “caput” assegurou ser dever de todos a proteção do meio ambiente para as presentes e futuras gerações, qualquer pessoa, constatando infração ambiental, poderá dirigir representação às autoridades acima mencionadas, para efeito do exercício do seu poder de polícia.

O auto de infração deverá ser lavrado pela autoridade ambiental que a houver constatado no local em que foi verificada a infração, devendo conter:

I. Nome do infrator, seu domicílio e/ou residência, bem como os demais elementos necessários à sua qualificação e identificação civil;

II. Local, data e hora da infração;

III. Descrição da infração e menção do dispositivo legal ou regulamentar transgredido;

IV. Penalidade a que estão sujeitos o infrator e o respectivo preceito legal que autoriza sua imposição;

V. Ciência, pelo autuado, de que responderá pelo fato em processo administrativo;

O inciso II, do artigo 71, da Lei de Crimes Ambientais estabelece, o prazo de 30 dias para a autoridade competente julgar o auto de infração, sendo que o referido prazo é contado da data da sua 
lavratura, apresentada ou não a sua defesa ou impugnação. Os recursos em $1^{\mathrm{a}}$ instância somente serão recebidos na unidade do órgão estadual de fiscalização que efetuou a fiscalização. O prazo máximo para a interposição de recursos em $2^{\mathrm{a}}$ instância será de 15 dias a contar do recebimento da notificação do $1^{\circ}$ julgamento.

O processo administrativo é o caminho pelo qual a administração pública exige, do particular, determinada obrigação, seja de fazer, não fazer ou até mesmo a exigência de uma prestação pecuniária. Os valores das multas serão proporcionais à degradação ambiental, em conformidade com o que estabelece o Decreto 99.274/90 e de acordo com tabela a ser elaborada pelo órgão ambiental competente e baixada por resolução (http://www.agroambiente.com.br/index.php). 


\section{Procedimentos Metodológicos}

Por método, podemos entender o caminho, a forma, o modo de pensamento. É a forma de abordagem em nível de abstração dos fenômenos. É o conjunto de processos ou operações mentais empregados na pesquisa (Prodanov, et.al., 2013, p. 26).

O método expressa uma relação entre ciência e filosofia, sendo a aplicação de formulações filosóficas no trabalho científico. É através dele que o cientista explicita as categorias e conceitos utilizados, define os procedimentos analíticos, circunscreve o objeto da investigação. O método envolve necessariamente uma teoria do conhecimento (Moraes, 2005, p.67).

Para que a hipótese da pesquisa seja respondida, será utilizado o seguinte cruzamento de informações:

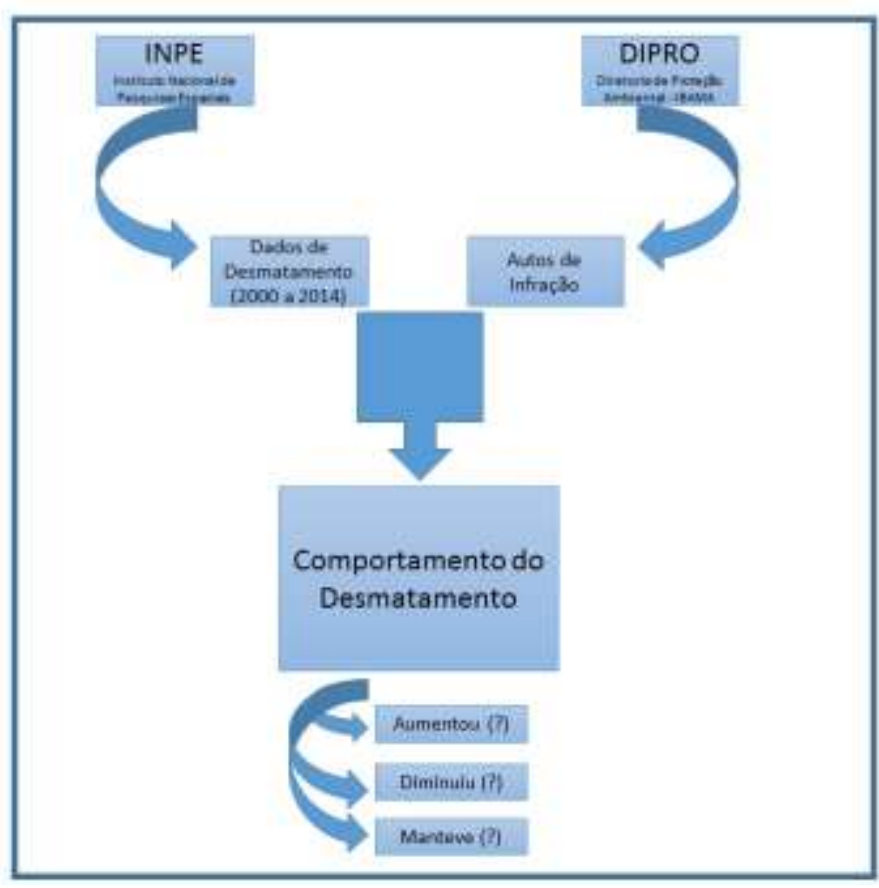

Figura 1: Como será respondido o objetivo do trabalho.

Será feita a divisão entre a quantidade de autos de infração pela taxa de desmatamento que resultará em um índice que mostre a relação existente entre esta taxa e o comportamento das taxas de desmatamento.

Para que o objetivo geral da pesquisa seja alcançado, será utilizado o método hipotéticodedutivo.

O método hipotético-dedutivo se inicia com um problema no conhecimento científico, passando pela formulação de hipótese e por um processo de inferência dedutiva, o qual testa a predição da ocorrência de fenômenos abrangidos pela referida hipótese (Prodanov et.al, 2013, p. 32). 
A pesquisa científica, com abordagem hipotético-dedutiva, tem início com a formulação de um problema e com sua descrição clara e precisa, a fim de facilitar a obtenção de um modelo simplificado e a identificação de outros conhecimentos e instrumentos, relevantes ao problema, que auxiliarão o pesquisador em seu trabalho. Após esse estudo preparatório, o pesquisador passa para a fase de observação. Na verdade, essa é a fase de teste do modelo simplificado. É uma fase meticulosa em que é observado determinado aspecto do universo, objeto da pesquisa. A fase seguinte é a formulação de hipóteses, ou descrições tentativas, consistentes com o que foi observado. Essas hipóteses são utilizadas para fazer prognósticos, os quais serão comprovados ou não por meio de testes, experimentos ou observações mais detalhadas. Em função dos resultados desses testes, as hipóteses podem ser modificadas, dando início a um novo ciclo, até que não haja discrepâncias entre a teoria e os experimentos e/ou observações (Prodanov, Freitas, 2013, p. 32,33).

O método hipotético-dedutivo pode ser apresentado a partir da seguinte sequência: Problema $\rightarrow$ Conjecturas $\rightarrow$ Dedução de consequências observadas $\rightarrow$ Tentativa de Falseamento $\rightarrow$ Corroboração (Prodanov, Freitas, 2013, p. 32).

A geografia, ciência de relações, implica um processo de pensamento específico que parte da descrição para chegar à explicação, em três termos principais: observação analítica, detecção das correlações e busca das relações de causalidade (George, 1986, p.07).

Em qualquer procedimento geográfico, o primeiro passo é a observação. Todavia, o comportamento normal da observação consiste em propor problemas que deverão ser resolvidos pela explicação. Parte desses problemas provém de dados que escapam ao alcance da observação, quer por se tratar de dados pertencentes ao passado e dos quais só se podem observar os efeitos, quer pelo fato de ser necessário levar em conta certas impulsões invisíveis e muitas vezes oriundas de centros de comando exteriores ao meio imediatamente considerado. Contudo, o visível e o invisível possuem algo em comum: pelo menos até certo ponto, tanto um como o outro são responsáveis pela dimensão (George, 1986, p.20).

A explicação dos fatos de observação lança mão de duas séries de dados: os dados estruturais e os dados históricos. Será conveniente incluir entre os dados estruturais tudo que entra na composição de um estado geográfico, tudo que entra nas combinações cujo conjunto é atingido pela observação, sob forma de paisagem geográfica, física e humana e são dos dados históricos que provêm os elementos que permitem o estabelecimento de uma interpretação evolutiva, já que a própria estrutura representa o resultado de uma evolução (George, 1986, p.30-32).

Para que seja possível atingir os objetivos propostos na pesquisa, ela se iniciará com a observação e análise dos dados oficiais referentes aos fatores econômicos e sociais das regiões 
estudadas e de desmatamento e tentar encontrar relações entre eles e as causas vinculadas a esse fenômeno.

A dialética trata da "coisa em si". Mas a "coisa em si" não se manifesta imediatamente ao homem. Por este motivo, o pensamento dialético distingue entre representação e conceito da coisa, com isso não pretendendo apenas distinguir duas formas e dois graus de conhecimento da realidade, mas especialmente e sobretudo duas qualidades da práxis humana. A atitude primordial e imediata do homem, em face da realidade, não é a de um abstrato sujeito cognoscente, de uma mente pensante que examina a realidade especulativamente, porém, a de um ser que age objetiva e praticamente, de um indivíduo histórico que exerce a sua atividade prática no trato com a natureza e com os outros homens, tendo em vista a consecução dos próprios fins e interesses, dentro de um determinado conjunto de relações sociais (Kosik, 1976, p.13).

Ao analisar a questão do desmatamento, é sempre importante lembrar que essa é uma prática que sempre ocorrerá tendo em vista a necessidade dos seres humanos em utilizar a madeira. O que deve ser tratado com os rigores da lei é o desmatamento ilegal. Muitas vezes as pessoas que trabalham nesse meio não percebem ou nunca foram estimulados a perceber o valor e a importância de se manter a floresta em pé ou pelo menos que a extração seja feita de uma maneira mais racional, menos destrutiva e sempre dentro da legalidade.

A práxis utilitária cotidiana cria "o pensamento comum" em que são captados tanto a familiaridade com as coisas e o aspecto superficial das coisas quanto a técnica de tratamento das coisas como forma de seu movimento e de sua existência. O pensamento comum é a forma ideológica do agir humano de todos os dias. Todavia, o mundo que se manifesta ao homem na práxis fetichizada, no tráfico e na manipulação, não é o mundo real, embora tenha a "consistência" e a validez do mundo real: é "o mundo da aparência". A representação da coisa não constitui uma qualidade natural da coisa e da realidade: é a projeção, na consciência do sujeito, de determinadas condições históricas petrificadas (Kosik, 1976, p.19).

A relação entre o ser humano e a natureza sempre vai depender dos interesses e dos objetivos que o homem tem para aquele local. Na verdade, os interesses preponderantes são das pessoas que possuem o poder de decisão para definir o que ocorrerá em determinado local, muitas vezes em detrimento ao que era a preferência de quem está no dia a dia local, mas que devido à conjuntura tem que se adequar ao que é determinado por aqueles que detêm o poder. 


\section{Materiais e Métodos}

\section{1. Área de Estudo}

A área de estudo da pesquisa será localizada nos sete Estados da Amazônia Legal que tem parte do seu território dentro do Arco do Desflorestamento. Os Estados são Acre, Amazonas, Maranhão, Mato Grosso, Pará, Rondônia e Tocantins. O Arco do Desflorestamento foi definido a partir das áreas mais problemáticas em relação ao desmatamento ilegal dentro do bioma Amazônico e por esse motivo foram escolhidos os Estados que foram analisados no trabalho. A área de estudo será todo o Estado e não apenas a parte do seu território que está contido dentro do Arco do Desflorestamento.

Segue o Mapa 3 que mostra os Estados da Amazônia Legal que tem parte do seu território dentro do Arco do Desflorestamento. 


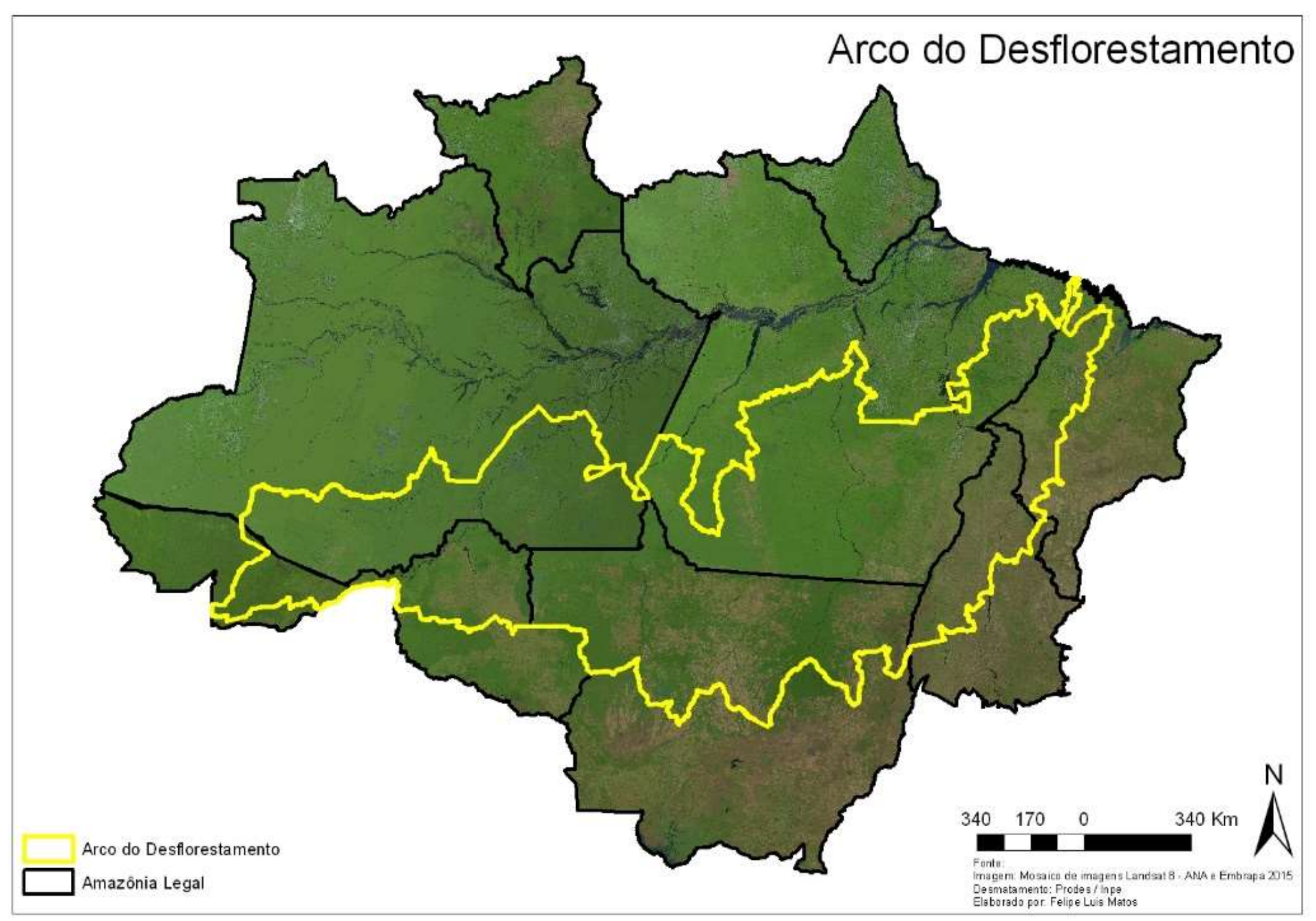

Mapa 3: Região do Arco do Desflorestamento. 


\subsection{Método de Trabalho}

O período escolhido para o desenvolvimento do trabalho foi entre os anos de 2000 e 2014 devido aos seguintes fatos: entre 2000 e 2004, ocorreu um aumento considerável nas taxas de desmatamento, chegando ao seu pico no ano de 2004. Nesse mesmo ano o governo brasileiro lançou o Plano de Prevenção e Controle do Desmatamento na Amazônia Legal (PPCDAM) que tinha como um dos seus objetivos melhorar e otimizar o monitoramento e o combate ao desmatamento ilegal e que isso possibilitasse a queda nas taxas oficiais de desmatamento.

O objetivo do trabalho é mostrar a importância, ou não, que a atuação do órgão fiscalizador, IBAMA, teve na queda nas taxas de desmatamento a partir do ano de 2005. A maneira encontrada para isso foi estabelecer uma relação entre a quantidade anual de autos de infração relacionados à flora nos Estados da Amazônia Legal com as taxas anuais de incremento de desmatamento.

Para isso, foi criado um índice que dividirá o total de autos de infração no ano pela quantidade de $\mathrm{km}^{2}$ desmatados. Esse índice será chamado de Índice de Multas por km². (IM/km²)

As informações referentes ao quantitativo de autos de infração foram conseguidas a partir da Lei de Acesso a Informação, que possui um link no site do Ibama que permite a qualquer cidadão solicitar informações referentes ao órgão, desde que não seja uma informação sigilosa.

Foi feita uma análise que relacionará as taxas anuais de desmatamento em cada um desses Estados com a quantidade de autos de infração lavrados. O Auto de Infração é a forma com a qual o órgão fiscalizador - IBAMA - tem de penalizar as pessoas ou empresas que estão praticando o desmatamento ilegal. Com isso, entenderemos se, após o lançamento do PPCDAM em 2004 passou - se a ter uma maior participação do IBAMA na diminuição das taxas de desmatamento no Brasil.

Para atingir o objetivo da pesquisa foi criado o índice de multas por $\mathrm{km}^{2}$ que, traz a quantidade anual de autos de infração por quilômetro quadrado de incremento anual de desmatamento, isto é, o número de autos de infração foi dividido pelo total de incremento de desmatamento ocorridos em cada ano. Se esse índice vier aumentando, possivelmente será um indicativo de que a presença do IBAMA foi importante e vem ajudando na queda das taxas.

Existem vários trabalhos na literatura que mostram os fatores que contribuem para o aumento das taxas de desmatamento, como o preço das commodities, preço do gado, valor da terra, entre outros, mas pesquisas que mostram a presença do Estado e a importância que ela tem no controle das taxas de desmatamento ainda são poucos. A partir desse índice, poderemos ter uma melhor noção da influência estatal nesse processo. 
Será utilizado o método estatístico da correlação. A correlação é a medida padronizada da relação entre duas variáveis. O coeficiente de correlação, $r$, é uma medida da intensidade da relação entre ou dentre as variáveis. A correlação não implica que um causa o outro. Podemos dizer que duas variáveis X e Y estão correlacionadas, mas não que X causa Y ou que Y causa X, na média. Eles simplesmente estão relacionados um com o outro (http://www.bertolo.pro.br).

A correlação nunca pode ser maior que 1 ou menor que -1. Uma correlação próxima a zero indica que as duas variáveis não estão relacionadas. Uma correlação positiva indica que as duas variáveis movem juntas, e a relação é forte quanto mais a correlação se aproxima de um. Uma correlação negativa indica que as duas variáveis se movem em direções opostas, e que a relação também fica mais forte quanto mais próxima de menos 1 a correlação ficar. Duas variáveis que estão perfeitamente correlacionadas positivamente $(\mathrm{r}=1)$ movem-se essencialmente em perfeita proporção na mesma direção, enquanto dois conjuntos que estão perfeitamente correlacionados negativamente movem-se em perfeita proporção em direções opostas (http://www.bertolo.pro.br).

\subsection{Origem dos Dados}

\subsubsection{Taxa de Desmatamento}

O dado oficial de desmatamento anual do Brasil é produzido pelo Instituto Nacional de Pesquisas Espaciais (INPE). Em meados dos anos 70, o Inpe começou a usar a tecnologia de sensoriamento remoto para mapear desmatamentos em florestas tropicais (INPE, 2013, p.03).

As estimativas geradas pelo PRODES baseiam-se em mapeamento anual de um grande conjunto de imagens do satélite Landsat 5/TM ou similares, cobrindo toda a extensão da Amazônia. O PRODES identifica áreas de corte raso, ou seja, retirada completa da cobertura florestal, maiores que 6,25 hectares. Áreas sob impacto de exploração seletiva de madeira e áreas degradadas por incêndios florestais foram ignoradas desde os primeiros levantamentos, por ser menos evidente em estágios iniciais de degradação e por apresentarem pequenas dimensões e extensões, sendo de difícil detecção com os instrumentos e técnicas utilizadas naquele período. Para possibilitar a comparação das taxas ano a ano e manter a compatibilidade da série histórica desta taxa, o PRODES permanece mapeando apenas desmatamento por corte raso (INPE, 2013, p.05).

Para início do mapeamento de determinado ano, o mapa de desmatamento do PRODES do ano anterior é utilizado como um marco de referência das áreas já desmatadas. Este mapa contendo o desmatamento dos anos anteriores, juntamente com as áreas de não - floresta e de hidrografia, geram 
uma máscara que contém todas as áreas de corte raso já detectados no passado. Esta máscara é usada para eliminar a possibilidade de que desmatamentos antigos sejam identificados, mapeados e contados novamente (INPE, 2013 p.23).

Em muitas áreas da Amazônia, é impossível obter imagens sem cobertura de nuvens pelo menos parcial. Nestes casos, o INPE procura selecionar a imagem com menor cobertura de nuvens dentro da estação seca (INPE, 2013 p.27).

\subsubsection{Auto de Infração}

As informações referentes ao quantitativo mensal de autos de infração de flora lavrados nos estados da Amazônia Legal foram obtidos a partir da Lei de Acesso a Informação. Ela permite ao cidadão consultar os órgãos do governo federal e buscar as informações, desde que não sejam sigilosas, de que necessita. No site do IBAMA, existe o Serviço de Informação ao Cidadão - SIC que é o responsável por analisar e referendar esses pedidos. 


\section{Resultados e Discussões}

Neste capítulo, serão mostrados os resultados obtidos na pesquisa e será realizada a discussão sobre os dados e informações trabalhadas.

\subsection{Amazônia Legal}

A Amazônia Legal, instituída em 1953 pela Lei $N^{\circ}$ 1.806, tem uma área de cerca de 5.217.423 $\mathrm{km}^{2}$, ocupando cerca de $61 \%$ do território brasileiro e, no entanto, abriga apenas $8,3 \%$ da população brasileira (Censo, 2010).

As principais atividades econômicas da região da Amazônia Legal são: extrativismo vegetal, pecuária e agricultura. Em algumas regiões ocorre também o desenvolvimento de atividades industriais como a mineração no Pará e também a Zona Franca de Manaus que é uma região onde a economia se baseia na atividade de indústrias pesadas e de eletroeletrônicos devido a política de isenção fiscal instituída em 28 de fevereiro de 1967 pelo Decreto-Lei $\mathrm{N}^{\circ} 288$ (http://www.infoescola.com/ecologia/amazonia-legal).

Segue o Mapa 4 que representa o desmatamento na Amazônia Legal no período entre 2000 e 2014. 


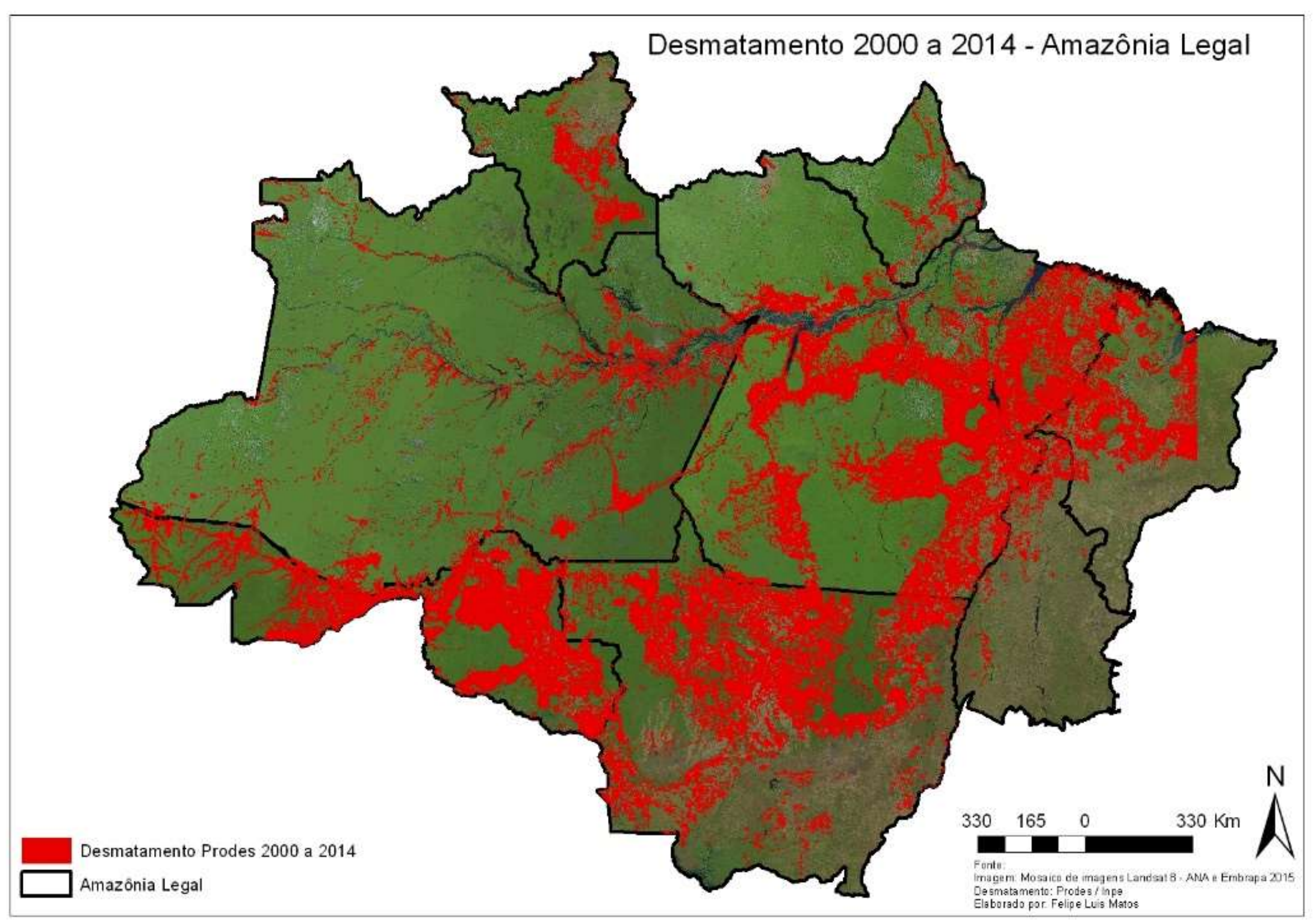

Mapa 4: Mapa do desmatamento na Amazônia Legal. 
Conforme o Gráfico 2, na Amazônia Legal, no período entre 2000 e 2004, antes do lançamento do PPCDAM, a taxa desmatamento variou entre 18165 e $27772 \mathrm{~km}^{2}$, tendo seu ápice no ano de 2004.

No período pós - PPCDAM, ou seja, de 2005 até 2014, a taxa de desmatamento variou entre 4571 e $19014 \mathrm{~km}^{2}$, tendo seu menor valor no ano de 2012.

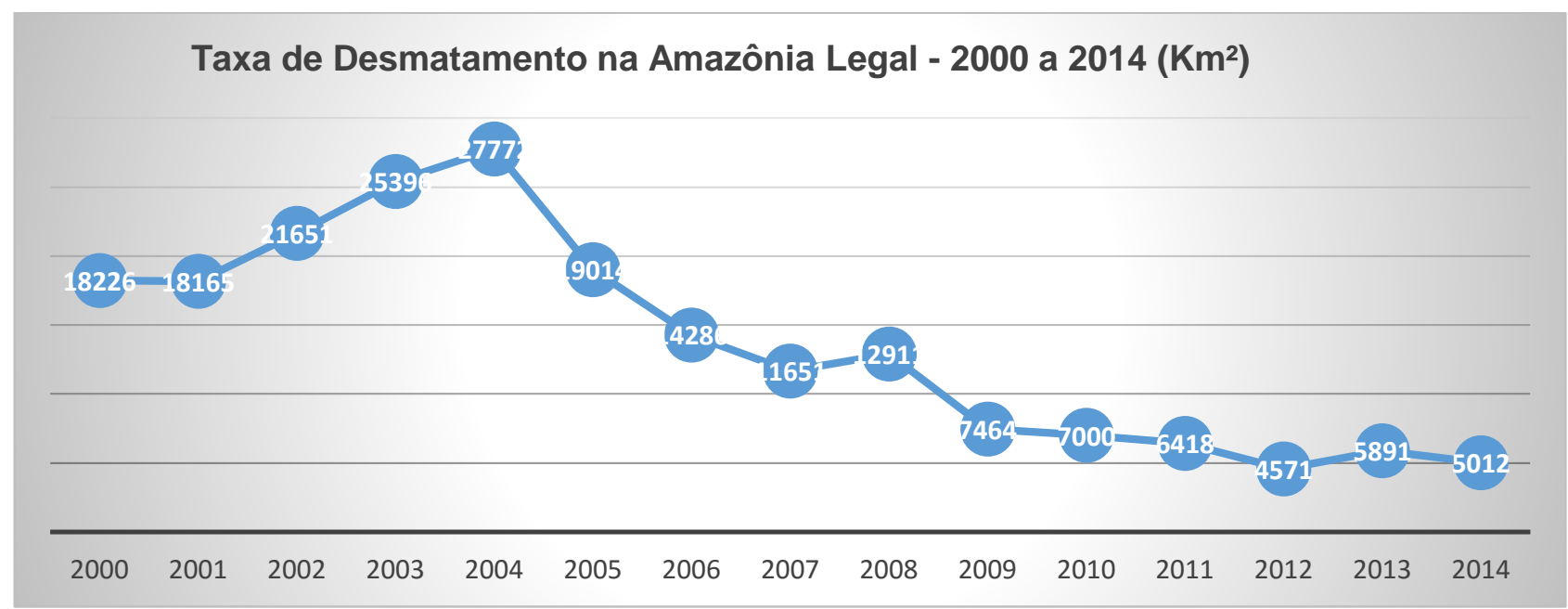

Gráfico 2: Taxa de Desmatamento na Amazônia Legal. Fonte: PRODES/INPE

No ano de 2005, primeiro ano após o lançamento do PPCDAM, ocorreu uma queda considerável na taxa de desmatamento, de $27772 \mathrm{~km}^{2}$ para $19014 \mathrm{~km}^{2}$, isto é, uma queda de $31,53 \%$ em relação a 2004. Nos anos de 2006 e 2007 a taxa de desmatamento continuou caindo consideravelmente.

No ano de 2008, houve um aumento na taxa de desmatamento. Após esse aumento, o governo passou a realizar operações de fiscalização de grande vulto no Estado do Pará e passou a subscrever a moratória da soja no Estado do Mato Grosso, situações que serão explicadas nos capítulos 6.2 e 6.3 .

Em 2009, a taxa voltou a cair consideravelmente, uma diminuição de 42,19\% em relação a 2008. A taxa continuou caindo constantemente até o ano de 2012. Em 2013, houve um novo acréscimo e, em 2014, caiu novamente.

Nos 10 anos de PPCDAM, ocorreram dois aumentos da taxa de desmatamento em relação ao ano anterior, e em ambos os casos os valores ficaram bem distantes do que eram anteriormente à implantação do PPCDAM. Nesse período, a queda da taxa de desmatamento foi de $81,95 \%$.

Conforme o Gráfico 3, na Amazônia Legal, no período entre 2000 e 2004, antes do lançamento do PPCDAM, a quantidade de autos de infração lavrados variou entre 4732 e 6351, tendo sua menor quantidade no ano de 2000. No período pós - PPCDAM, ou seja, de 2005 até 2014, a quantidade de autos de infração lavrados variou entre 4172 e 8590, tendo seu maior índice no ano de 2005. 


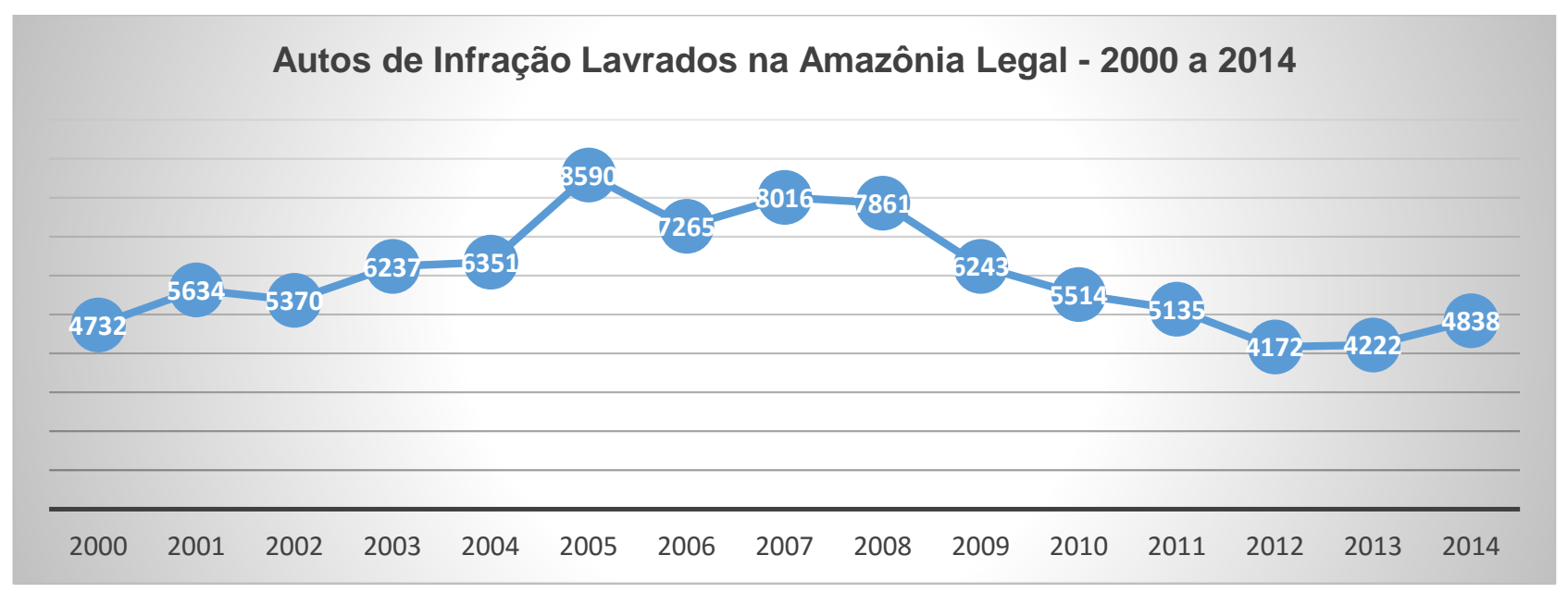

Gráfico 3: Autos de Infração Lavrados na Amazônia Legal. Fonte: IBAMA

No ano de 2005, primeiro ano após o lançamento do PPCDAM, ocorreu um aumento de 35,25 \% na quantidade de autos de infração lavrados na Amazônia Legal, passando de 6351 para 8590.

Em 2006, a quantidade de autos de infração foi menor que em 2005. Em 2007, houve um novo aumento no total de autos de infração lavrados e, de 2008 a 2012, a quantidade foi caindo ano a ano, voltando a aumentar novamente em 2013 e 2014.

Apesar de em muitos dos anos observados não ter ocorrido o aumento na quantidade de autos de infração lavrados em relação ao ano anterior, é importante perceber que isso não resultou no aumento da taxa de desmatamento. Desde 2005, as taxas veem diminuindo com uma certa constância, exceção feita a 2007-2008 e 2012-2013, o que pode ser um sinal que a criação de um programa de governo (PPCDAM) que priorizou o monitoramento, combate e controle do desmatamento ilegal teve importância na diminuição dos índices de desmatamento. Com a queda na taxa de desmatamento, é natural que também ocorra diminuição nos autos de infração relativos a flora.

Conforme o Gráfico 4, no período entre 2000 e 2004, antes do lançamento do PPCDAM, o índice de multas por $\mathrm{km}^{2}$ variou entre 0,23 e 0,31 multas por $\mathrm{km}^{2}$, tendo seu pior desempenho no ano de 2004. No período pós PPCDAM, ou seja, de 2005 até 2014, o índice de multas por $\mathrm{km}^{2}$ variou entre 0,45 e 0,97 multas por $\mathrm{km}^{2}$, tendo seu maior índice no ano de 2014. 


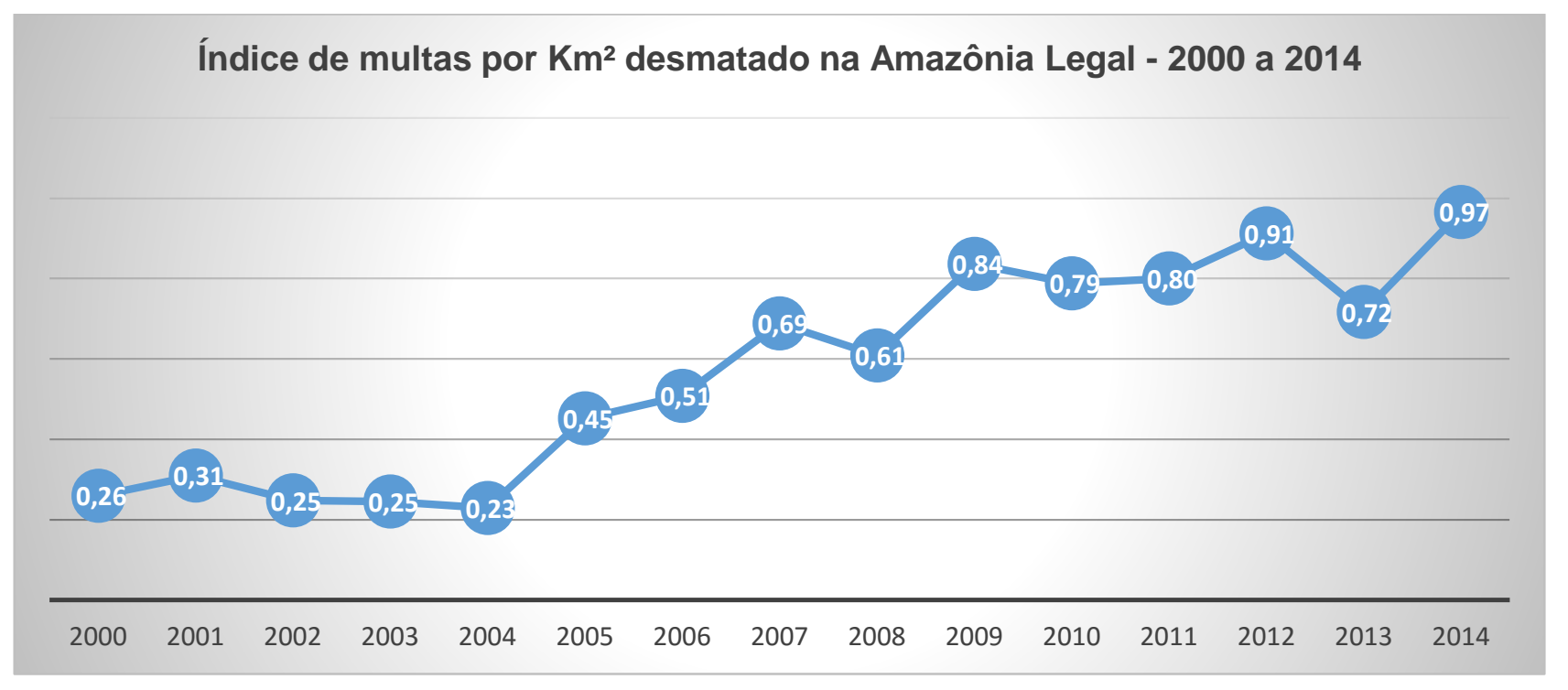

Gráfico 4: Índice de Multas por $\mathrm{Km}^{2}$ desmatado na Amazônia Legal.

A quantidade de multas por $\mathrm{km}^{2}$ desmatado mostra a relação entre a atuação do Ibama, através da lavratura de autos de infração e o total desmatado na Amazônia Legal em cada ano.

No Gráfico 4, percebemos que, no período entre 2000 e 2004, o índice de multas por km² foi bem parecido, acontecendo uma pequena diferença apenas no ano de 2001.

Em 2005, o índice de multas por $\mathrm{km}^{2}$ praticamente dobrou em relação a 2004. Ele continuou aumentando nos anos de 2006 e 2007. Em 2008, ele diminuiu em relação a 2007, voltando a aumentar em 2009. Em 2010, caiu novamente e se manteve praticamente igual em 2011. Em 2012, voltou a aumentar seguido de uma nova queda em 2013 e subindo e atingindo o seu maior valor histórico no ano de 2014.

É importante ressaltar que, após o lançamento do PPCDAM, em todos os anos, os índices de multa por $\mathrm{km}^{2}$ foram maiores do que no período anterior a ele.

O índice de correlação entre as variáveis taxa de desmatamento e autos de infração lavrados foi de 0,35 , ou seja, $r=0,35$. Esse valor de $r$ indica que há uma relação positiva entre essas duas variáveis, ou seja, elas se movem de forma conjunta.

$\mathrm{O}$ aumento do índice de multas por $\mathrm{km}^{2}$ é um fato que mostra a importância da maior presença do Estado nas áreas que sofrem com o desmatamento ilegal e que acabou impactando, juntamente com outros fatores, na queda da taxa de desmatamento nos últimos 10 anos.

Logo após o lançamento do PPCDAM, a quantidade absoluta de autos de infração aumentou consideravelmente, possivelmente fruto do primeiro esforço para coibir a prática ilegal do desmatamento. A partir do momento que a taxa de desmatamento foi caindo é natural que a quantidade de autos de infração também caísse, mas a relação entre eles não caiu, pelo contrário, 
sempre se manteve bem acima do que era antes do PPCDAM. Mesmo que nos últimos anos, em números absolutos, a quantidade de autos de infração tenha diminuído, isso é um ótimo sinal, pois a taxa de desmatamento também diminuiu.

Em todos os anos após o lançamento do PPCDAM, o índice de multas por $\mathrm{km}^{2}$ foi maior do que antes dele ser criado. Esse pode ser um indicativo que a presença efetiva do Estado através de uma política de governo integrada entre diversos entes da federação tem importância para o controle do desmatamento ilegal.

A partir da análise do índice de multas por $\mathrm{km}^{2}$, podemos inferir que a presença mais efetiva do órgão fiscalizador, juntamente com adoção de medidas integradas de comando e controle entre diversos órgãos do Estado, após o lançamento do PPCDAM, foi importante para a queda nos índices de desmatamento na Amazônia Legal.

\subsection{Pará}

O Estado do Pará tem aproximadamente 1.247 .954 km² de extensão territorial. A população no Estado do Pará, segundo o IBGE, no ano de 2010 era de 7.581.051 habitantes (www.ibge.gov.br/estadosat).

A agricultura, a pecuária e a extração vegetal possuem destaque na economia paraense (www.pa.gov.br).

Dentro da estrutura da Secretaria de Meio Ambiente e Sustentabilidade (SEMAS - PA), existe uma Diretoria de Fiscalização que tem por finalidade proteger, preservar, conservar e controlar o uso dos recursos naturais de forma sustentável, buscando melhor qualidade de vida e desenvolvimento sustentável para as atuais e futuras gerações (www.semas.pa.gov.be/diretorias/fiscalizacao).

Segue o Mapa 5 que representa o desmatamento no Estado do Pará no período entre 2000 e 2014. 


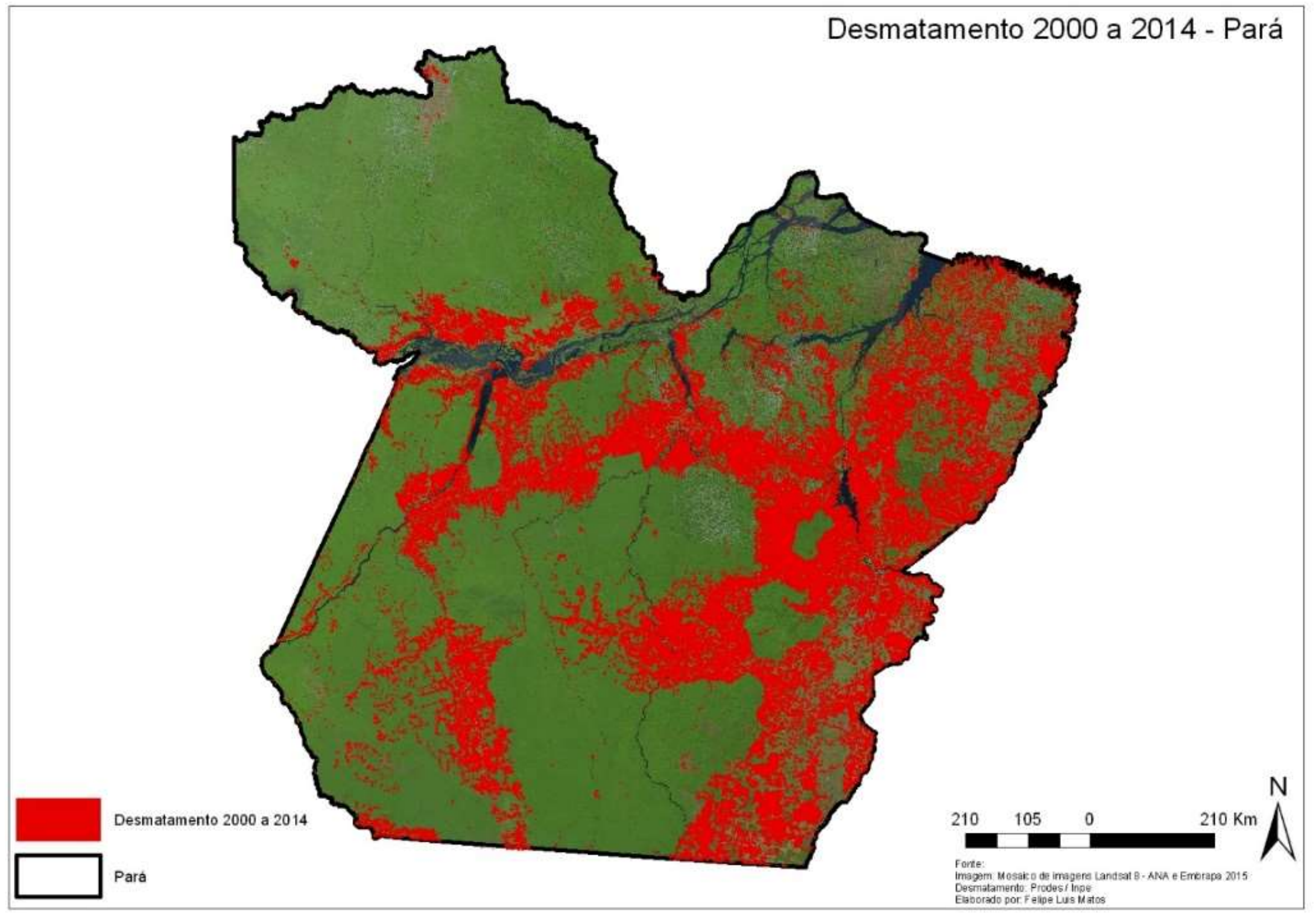

Mapa 5: Mapa do desmatamento no Estado do Pará 
Conforme o Gráfico 5, no Estado do Pará no período entre 2000 e 2004, antes do lançamento do PPCDAM, a taxa de desmatamento variou entre 5237 e $8870 \mathrm{~km}^{2}$, tendo seu ápice no ano de 2004. No período pós - PPCDAM, ou seja, de 2005 até 2014, a taxa de desmatamento variou entre 1741 e $5899 \mathrm{~km}^{2}$, tendo seu menor valor no ano de 2012.

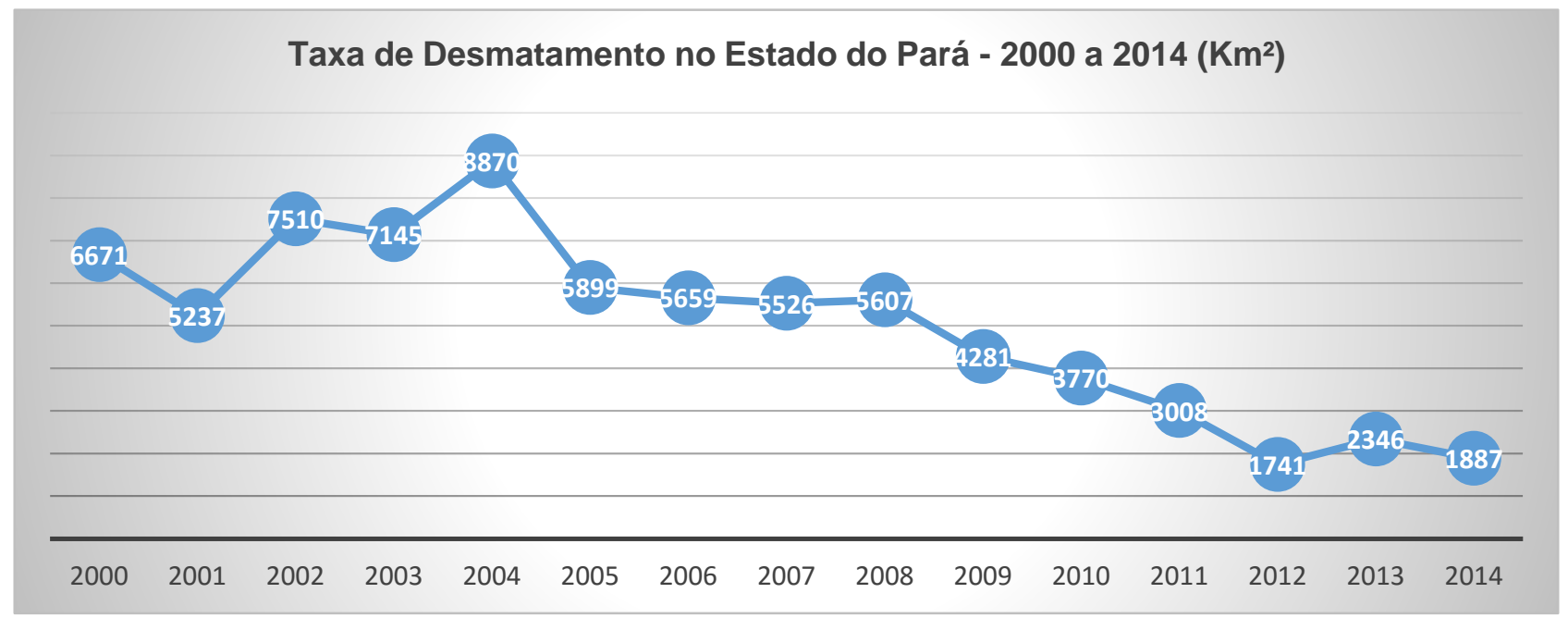

Gráfico 5: Taxa de Desmatamento no Estado do Pará. Fonte: PRODES/INPE

No ano de 2005, primeiro ano após o lançamento do PPCDAM, ocorreu uma queda considerável na taxa de desmatamento, de $8870 \mathrm{~km}^{2}$ para $5899 \mathrm{~km}^{2}$, isto é, uma queda de 33,5\% em relação a 2004. Nos anos de 2006 a 2008, as taxas de desmatamento se mantiveram numa certa estabilidade, sem haver uma diminuição considerável.

Devido a isso, no ano de 2008, ocorreram na região do Mosaico de Unidades de Conservação da Terra do Meio no Estado do Pará, a operação Esperança I que tinha como objetivo reintegrar terras públicas que foram ocupadas irregularmente e a operação Boi Pirata que tinha como objetivo retirar o gado que se encontrava em fazendas dentro de unidades de conservação.

As operações ocorreram nessa região pois era lá que ocorria uma parte considerável do desmatamento ilegal no Estado do Pará devido à grilagem de terras e à criação de gado em terras públicas.

Em 2009, a taxa de desmatamento teve uma queda de 23,64\% em relação a 2008, ou seja, foi de 5607 para $4281 \mathrm{~km}^{2}$. Ela continuou a cair nos anos de 2010, 2011 e 2012, tendo atingido em 2012 o seu menor índice, que foi de $1741 \mathrm{~km}^{2}$.

Em 2013 a taxa de desmatamento voltou a ter um crescimento de $34,75 \%$, indo de $1741 \mathrm{~km}^{2}$ para $2346 \mathrm{~km}^{2}$. Uma das causas desse aumento pode ter sido a discussão do novo código florestal que 
acontecia na época e que dentre vários assuntos tratava da anistia e perdão de multas relativas a áreas anteriormente desmatadas.

Em janeiro de 2013, teve início a Operação Onda Verde que diferentemente de outras operações, trabalhava com bases móveis e autônomas localizadas em pontos estratégicos para o combate ao desmatamento. Ela ocorre de forma ininterrupta e ainda continua em andamento. A operação é uma parceria entre Ibama, Polícia Rodoviária Federal, Força Nacional de Segurança e Polícia Federal.

Em 2014, a taxa voltou a ter uma queda de $19,56 \%$ chegando a $1887 \mathrm{~km}^{2}$ desmatados.

Desde o início do PPCDAM, ocorreu uma diminuição considerável nos índices de desmatamento no Estado do Pará. Em 2005, primeiro ano do PPCDAM, a taxa de desmatamento foi de $5899 \mathrm{~km}^{2}$ e em 2014, $1887 \mathrm{~km}^{2}$. Nesse período, ocorreu uma redução de $68,01 \%$ no desmatamento no Estado do Pará.

Conforme o Gráfico 6, no Estado do Pará, no período entre 2000 e 2004, antes do lançamento do PPCDAM, a quantidade de autos de infração lavrados variou entre 1376 e 2141, tendo sua menor quantidade no ano de 2004. No período pós PPCDAM, ou seja, de 2005 até 2014, a quantidade de autos de infração lavrados variou entre 1180 e 2448, tendo seu maior índice no ano de 2005.

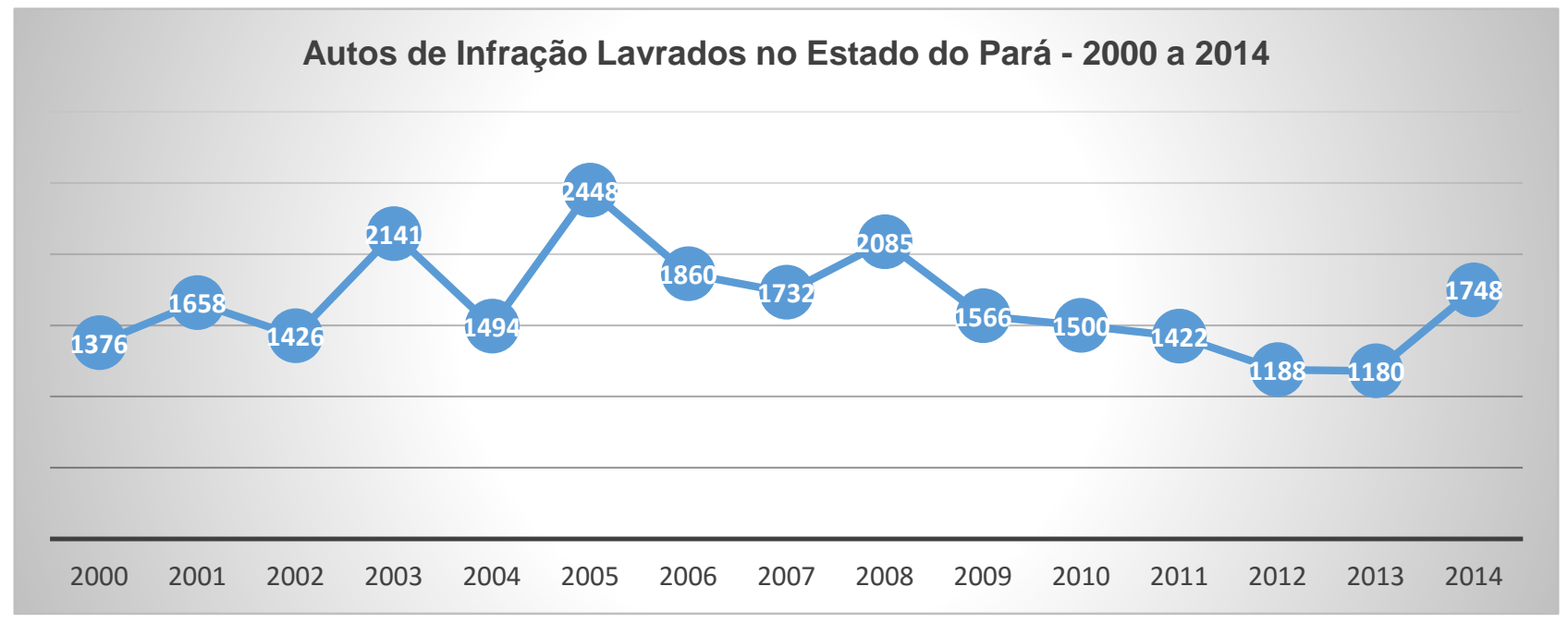

Gráfico 6: Autos de Infração Lavrados no Estado do Pará. Fonte: IBAMA

No ano de 2005, primeiro ano após o lançamento do PPCDAM, ocorreu um aumento de 63,58\% na quantidade de autos de infração lavrados no Estado do Pará passando de 1494 para 2448.

Em 2006 e 2007, a quantidade de autos de infração foi menor que em 2005. Em 2008, houve um novo aumento no total de autos de infração lavrados e de 2009 a 2013 a quantidade foi caindo ano a ano voltando a aumentar novamente em 2014. 
Conforme o Gráfico 7, no período entre 2000 e 2004, antes do lançamento do PPCDAM, o índice de multas por $\mathrm{km}^{2}$ variou entre 0,17 e 0,32 multas por $\mathrm{km}^{2}$, tendo seu pior desempenho no ano de 2004. No período pós PPCDAM, ou seja, de 2005 até 2014, o índice de multas por km² variou entre 0,31 e 0,93 multas por $\mathrm{km}^{2}$, tendo seu maior índice no ano de 2014.

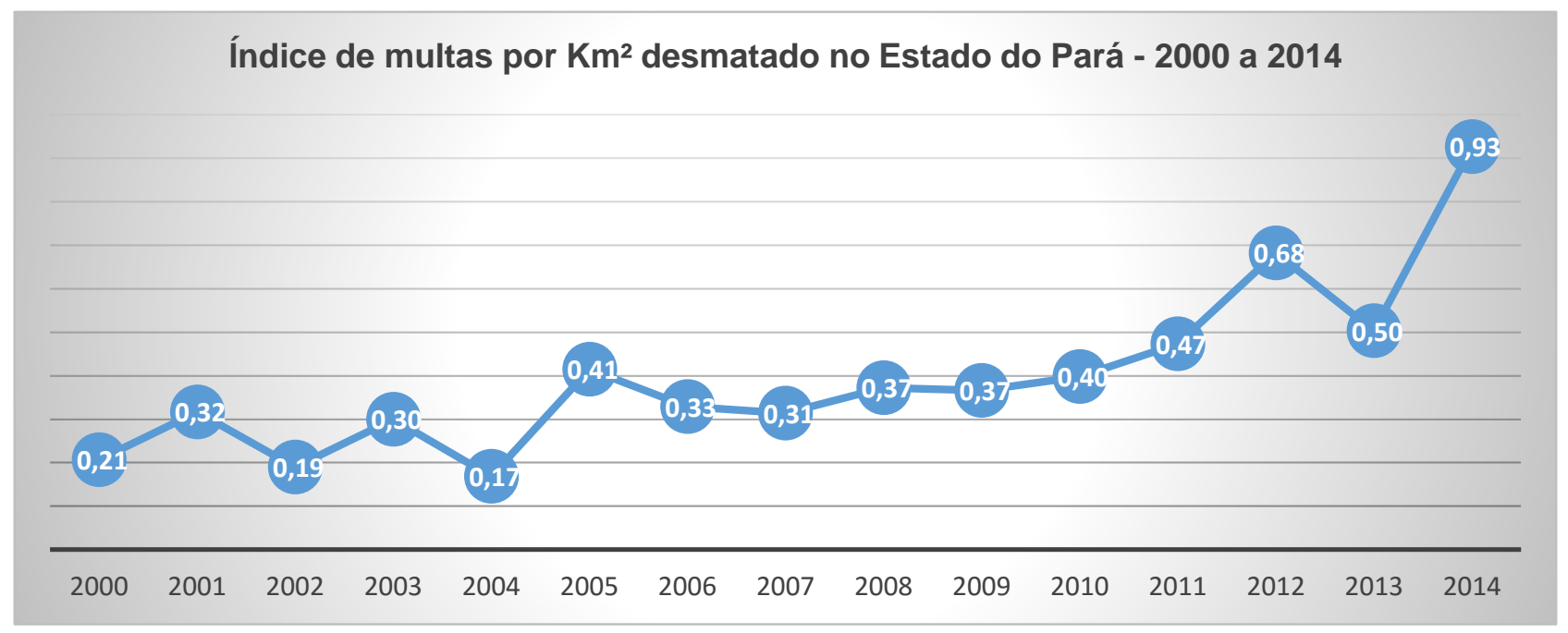

Gráfico 7: Índice de Multas por $\mathrm{Km}^{2}$ desmatado no Estado do Pará.

No Gráfico 7, percebemos que no período entre 2000 e 2004, ocorria ano após ano, uma variação tanto para mais quanto para menos no índice, ou seja, não existia um padrão nesse índice.

Em 2005, houve um aumento considerável no índice, seguido de duas quedas nos anos de 2006 e 2007. A partir daí, o índice veio aumentando constantemente até o ano de 2012, quando ocorreu novamente uma queda considerável no ano de 2013. Em 2014, o índice aumentou novamente, tendo atingido seu ápice nesse ano.

O índice de correlação entre as variáveis taxa de desmatamento e autos de infração lavrados foi de 0,35 , ou seja, $r=0,35$. Esse valor de $r$ indica que há uma relação positiva entre essas duas variáveis, ou seja, elas se movem de forma conjunta. Coincidentemente, o índice de correlação do Estado do Pará foi igual ao da Amazônia Legal.

É importante ressaltar que, após o lançamento do PPCDAM, em todos os anos, os índices de multa por $\mathrm{km}^{2}$ foram maiores do que no período anterior a ele, exceção feita ao ano de 2007 que teve índice menor que em 2001.

A partir da análise do índice de multas por $\mathrm{km}^{2}$, podemos inferir que a presença mais efetiva do órgão fiscalizador, juntamente com adoção de medidas integradas de comando e controle entre diversos órgãos do Estado, após o lançamento do PPCDAM, foram importantes para a queda nos índices de desmatamento no Estado do Pará. 


\subsection{Mato Grosso}

O Estado do Mato Grosso tem aproximadamente $903.378 \mathrm{~km}^{2}$ de extensão territorial. A população no Estado do Mato Grosso, segundo o IBGE, no ano de 2010 era de 3.035.122 habitantes (www.ibge.gov.br/estadosat).

O Mato Grosso é conhecido como o celeiro do país, campeão na produção de soja, milho, algodão e de rebanho bovino (www.mt.gov.br).

Dentro da estrutura da Secretaria de Estado de Meio Ambiente (SEMA - MT), existe a Superintendência de Fiscalização, cujas competências são: planejar, executar e avaliar a fiscalização de empreendimentos e atividade efetiva ou potencialmente poluente e o uso ou exploração dos recursos naturais; subsidiar a elaboração e atualizações normativas inerentes às ações de fiscalização; supervisionar as atividades de fiscalização do Estado; promover a elaboração de planos de fiscalização em conjunto com as demais superintendências e órgãos afins; propor, subsidiar e supervisionar ações de prevenção e controle de desmatamentos e queimadas, dentre outras atribuições (www.sema.mt.gov.br).

Segue o Mapa 6 que representa o desmatamento no Estado do Mato Grosso no período entre 2000 e 2014. 


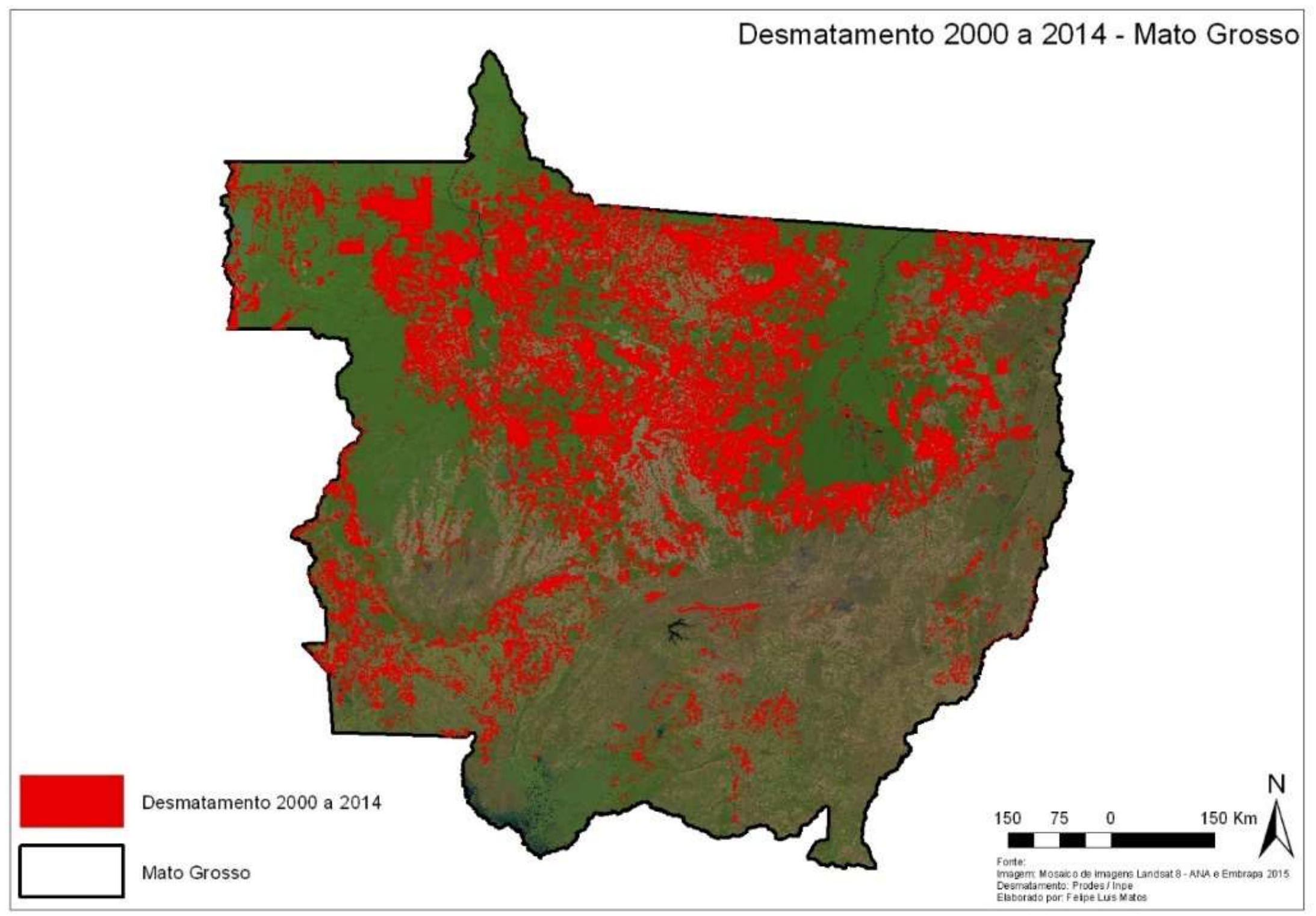

Mapa 6: Mapa do desmatamento no Estado do Mato Grosso. 
Conforme o Gráfico 8, no Estado do Mato Grosso, no período entre 2000 e 2004, antes do lançamento do PPCDAM, a taxa de desmatamento variou entre 6369 e $11814 \mathrm{~km}^{2}$, tendo seu ápice no ano de 2004. No período pós PPCDAM, ou seja, de 2005 até 2014, a taxa de desmatamento variou entre 757 e $7145 \mathrm{~km}^{2}$, tendo seu menor valor no ano de 2012 .

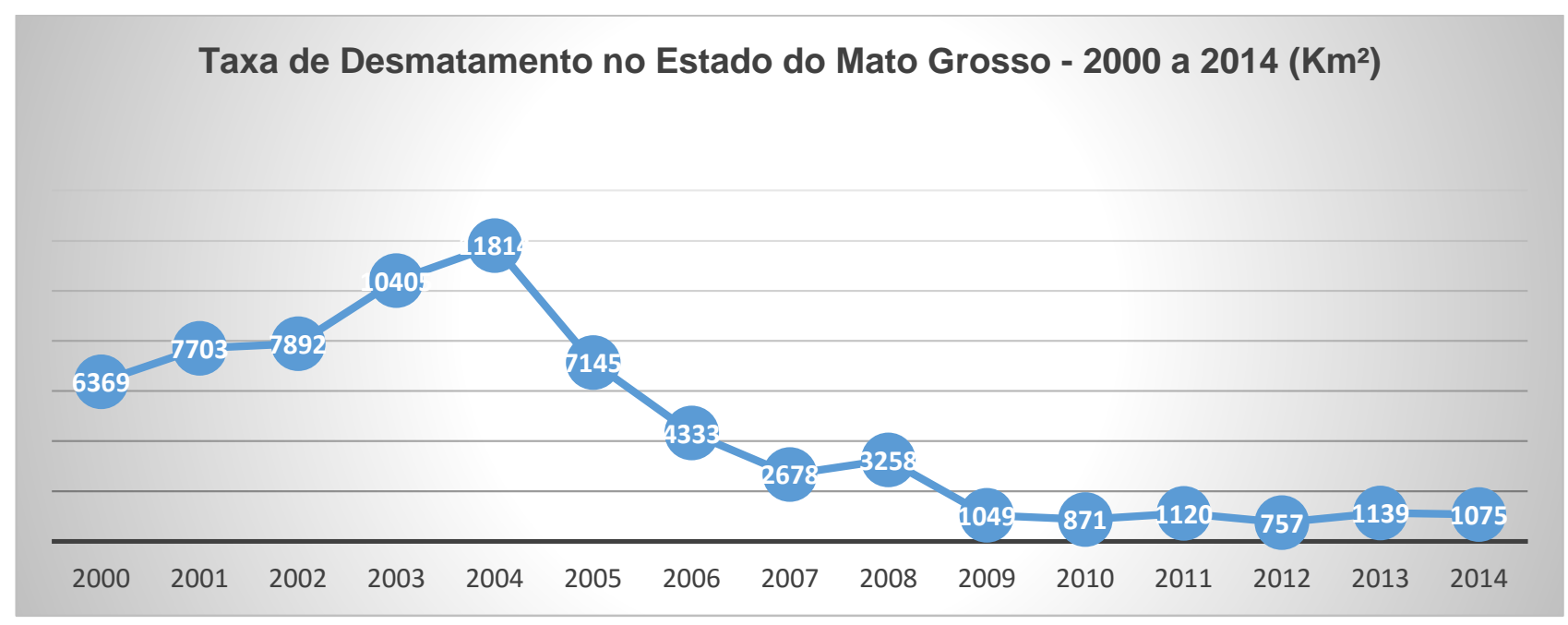

Gráfico 8: Taxa de Desmatamento no Estado do Mato Grosso. Fonte: PRODES/INPE

No ano de 2005, primeiro ano após o lançamento do PPCDAM, ocorreu uma queda considerável na taxa de desmatamento, de $11814 \mathrm{~km}^{2}$ para $7145 \mathrm{~km}^{2}$, isto é, uma queda de $39,52 \%$ em relação a 2004. A taxa continuou caindo até o ano de 2007. Em 2008, ocorreu um novo aumento e, em 2009, outra queda considerável que foi de 67,8\% em relação ao ano anterior. Nos anos de 2011 e 2013, houve aumento em relação ao ano anterior. Em 2014, voltou a cair novamente.

Em 2005, ocorreu, no Mato Grosso, a Operação Curupira, realizada pelo Ibama e Polícia Federal, que prendeu cerca de 85 pessoas dentre empresários, despachantes e servidores públicos que atuavam na extração e transporte ilegal de madeira. Dentre os presos, estavam o então Secretário do Meio Ambiente, o então Superintendente do Ibama e o então Presidente da Fundação Estadual do Meio Ambiente. Os empresários eram acusados de pagar propina para aprovar projetos irregulares e extrair madeira de áreas proibidas e os servidores públicos eram acusados de vender Autorizações de Transporte de Produtos Florestais (ATPFs) para empresas fantasmas e de autorizar empreendimentos irregulares.

Em 2006, foi iniciada a moratória da soja que foi um pacto ambiental entre as entidades representativas produtoras de soja, ONGs ambientais e mais tarde, o próprio governo que previa a adoção de medidas contra o desmatamento da Amazônia e que inicialmente tece o prazo de duração de dois anos a partir de 24 de julho de 2006. A ideia era de que, a partir desta data, não fosse comercializada nenhuma soja proveniente de áreas que foram desmatadas após essa data. Em 2008, 
o governo subscreveu esse projeto e passou a colaborar com ele. O programa foi renovado várias vezes e agora vale até maio de 2016.

Em janeiro de 2013, teve início a Operação Onda Verde que, diferentemente de outras operações, trabalhava com bases móveis e autônomas localizadas em pontos estratégicos para o combate ao desmatamento. Ela também ocorreu de forma ininterrupta e ainda continua em andamento. A operação é uma parceria entre Ibama, Polícia Rodoviária Federal, Força Nacional de Segurança e Polícia Federal.

Em 2014, a taxa voltou a ter uma queda, de 5,62\%, chegando a $1075 \mathrm{~km}^{2}$ desmatados.

Desde o início do PPCDAM, ocorreu uma diminuição considerável nos índices de desmatamento no Estado do Mato Grosso. Em 2005, primeiro ano do PPCDAM a taxa de desmatamento foi de $7145 \mathrm{~km}^{2}$ e em 2014, $1075 \mathrm{~km}^{2}$. Nesse período ocorreu uma redução de 84,95\% no desmatamento no Estado do Mato Grosso.

Conforme o Gráfico 9, no Estado do Mato Grosso, no período entre 2000 e 2004, antes do lançamento do PPCDAM, a quantidade de autos de infração lavrados variou entre 1170 e 2001, tendo sua menor quantidade no ano de 2000. No período pós - PPCDAM, ou seja, de 2005 até 2014, a quantidade de autos de infração lavrados variou entre 864 e 1941, tendo seu maior índice no ano de 2005.

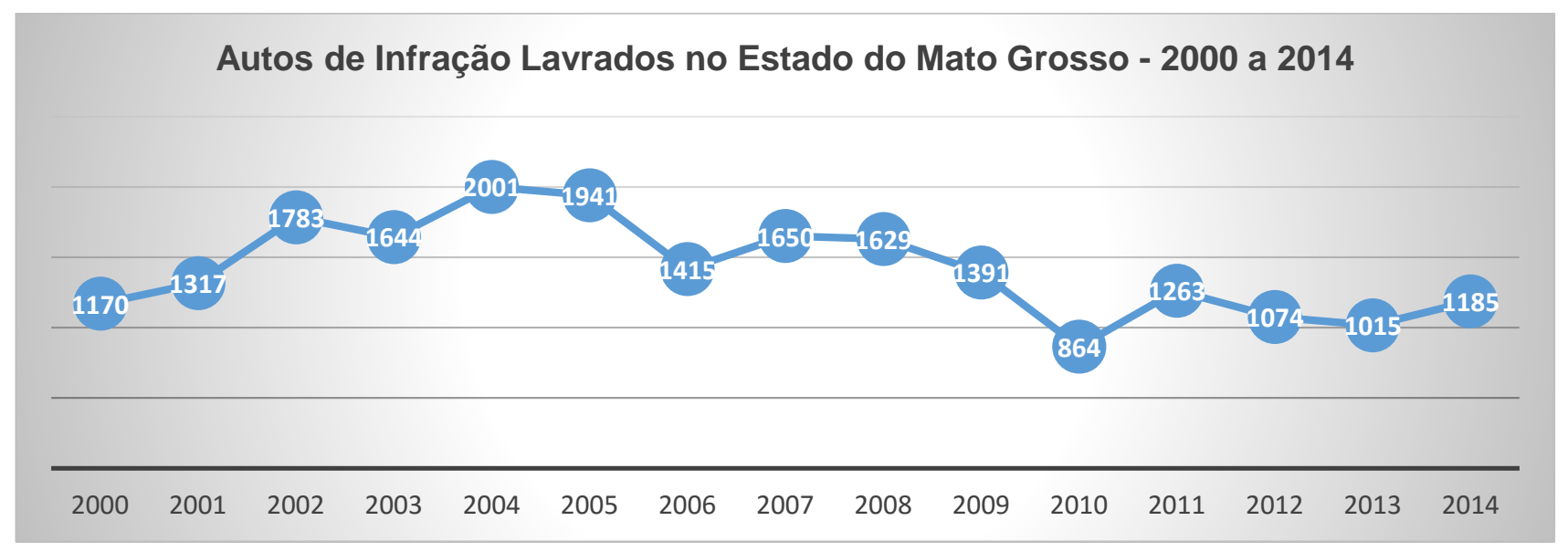

Gráfico 9: Autos de Infração Lavrados no Estado do Mato Grosso. Fonte: IBAMA

No ano de 2005, primeiro ano após o lançamento do PPCDAM, ocorreu uma diminuição de 3,0\% na quantidade de autos de infração lavrados no Estado do Mato Grosso, passando de 2001 para 1941.

Em 2006 a quantidade de autos de infração foi menor que em 2005. Em 2007, houve um aumento no total de autos de infração lavrados. Nos anos de 2008 a 2010, a quantidade de autos 
continuou diminuindo, tendo aumentado novamente em 2011. Em 2012 e 2013, a quantidade voltou a cair e, em 2014, teve um novo aumento.

Conforme o Gráfico 10, no período entre 2000 e 2004, antes do lançamento do PPCDAM, o índice de multas por $\mathrm{km}^{2}$ variou entre 0,16 e 0,23 multas por $\mathrm{km}^{2}$, tendo seu pior desempenho no ano de 2003. No período pós - PPCDAM, ou seja, de 2005 até 2014, o índice de multas por km² variou entre 0,27 e 1,42 multas por $\mathrm{km}^{2}$, tendo seu maior índice no ano de 2012.

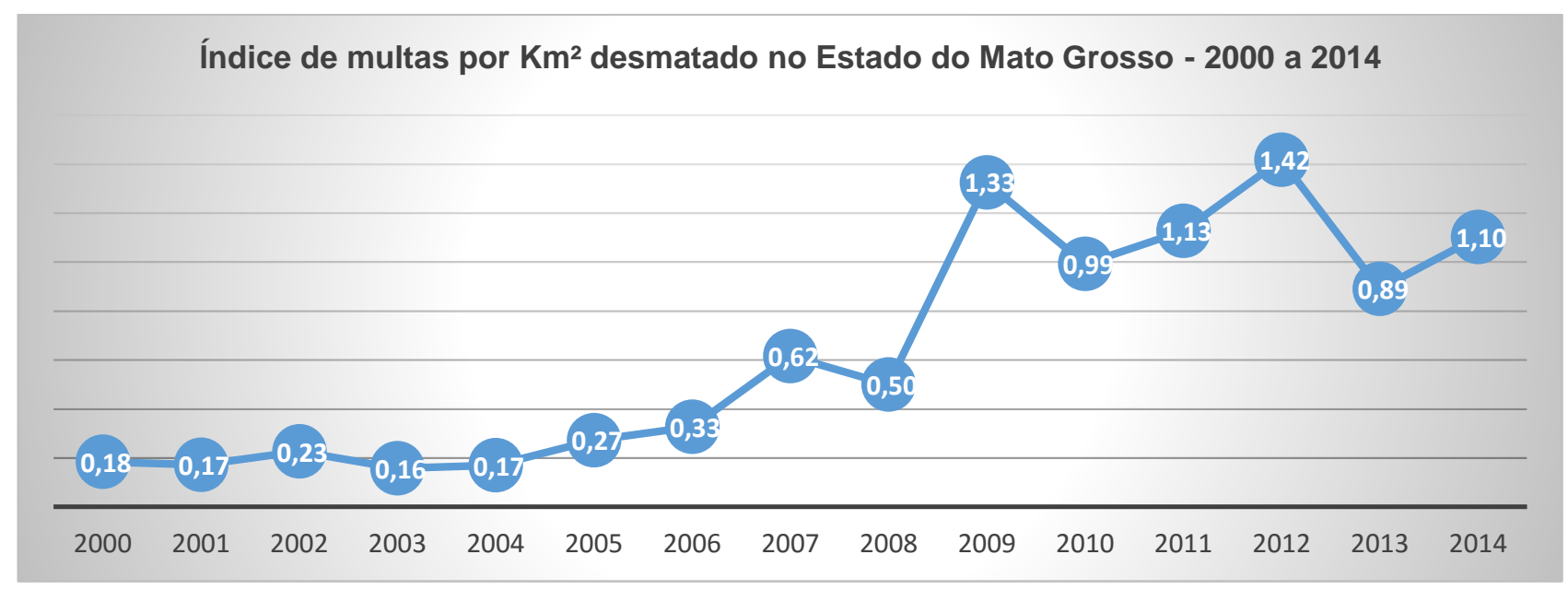

Gráfico 10: Índice de Multas por $\mathrm{Km}^{2}$ desmatado no Estado do Mato Grosso.

No Gráfico 10, percebemos que, no período entre 2000 e 2004, o índice tinha uma pequena variação tanto para mais quanto para menos, mas o seu valor era bem baixo.

A partir de 2005, primeiro ano efetivo do PPCDAM, ele passou a subir consideravelmente, atingindo o ápice até então no ano de 2007. Em 2008, o índice voltou a cair, mas mesmo assim continuou bem acima do período anterior ao PPCDAM. Em 2009, o índice subiu novamente, caiu em 2010, voltou a subir em 2011 e atingiu seu ápice histórico em 2012. No ano de 2013, o índice caiu novamente e voltou a subir em 2014. Mesmo tendo essa variação anual, a partir de 2007, os índices sempre foram bem maiores do que eram no período anterior ao PPCDAM.

O índice de correlação entre as variáveis taxa de desmatamento e autos de infração lavrados foi de 0,71 , ou seja, $r=0,71$. Esse valor de $r$ indica que há uma relação bastante positiva entre essas duas variáveis, ou seja, elas se movem de forma conjunta.

É importante ressaltar que, após o lançamento do PPCDAM, em todos os anos, os índices de multa por $\mathrm{km}^{2}$ foram bem maiores do que no período anterior a ele.

A partir da análise do índice de multas por $\mathrm{km}^{2}$, podemos inferir que a presença mais efetiva do órgão fiscalizador, juntamente com adoção de medidas integradas de comando e controle entre diversos órgãos do Estado, após o lançamento do PPCDAM, foram importantes para a queda nos índices de desmatamento no Estado do Mato Grosso. 


\subsection{Rondônia}

O Estado de Rondônia tem aproximadamente $237.590 \mathrm{~km}^{2}$ de extensão territorial. A população no Estado de Rondônia, segundo o IBGE, no ano de 2010 era de 1.562.409 habitantes (www.ibge.gov.br/estadosat).

A economia de Rondônia tem, como principais atividades, o extrativismo vegetal e mineral, a agricultura e a pecuária. A exploração de madeira e a borracha são as principais atividades do extrativismo vegetal em Rondônia. O principal mineral explorado no Estado é a cassiterita. Na agricultura, a produção de grãos é a principal atividade (http://www.infoescola.com/economia/economia-de-rondonia).

Dentro da estrutura da Secretaria de Estado do Desenvolvimento Ambiental de Rondônia, existe a Coordenadoria de Desenvolvimento Florestal e Faunístico que, dentre outras atividades, tem como função: participar na formulação de políticas e diretrizes do desenvolvimento ambiental; formular planos, programas e projetos de desenvolvimento florestal e faunístico; promover a política de controle, licenciamento e monitoria do uso sustentável dos recursos florestais, fluxo de transporte estadual e interestadual, beneficiamento, industrialização e comercialização dos produtos e subprodutos florestais (http://www.sedam.ro.gov.br/index.php/component/content/article/114codef/161-codef).

Segue o Mapa 7 que representa o desmatamento no Estado de Rondônia no período entre 2000 e 2014 . 


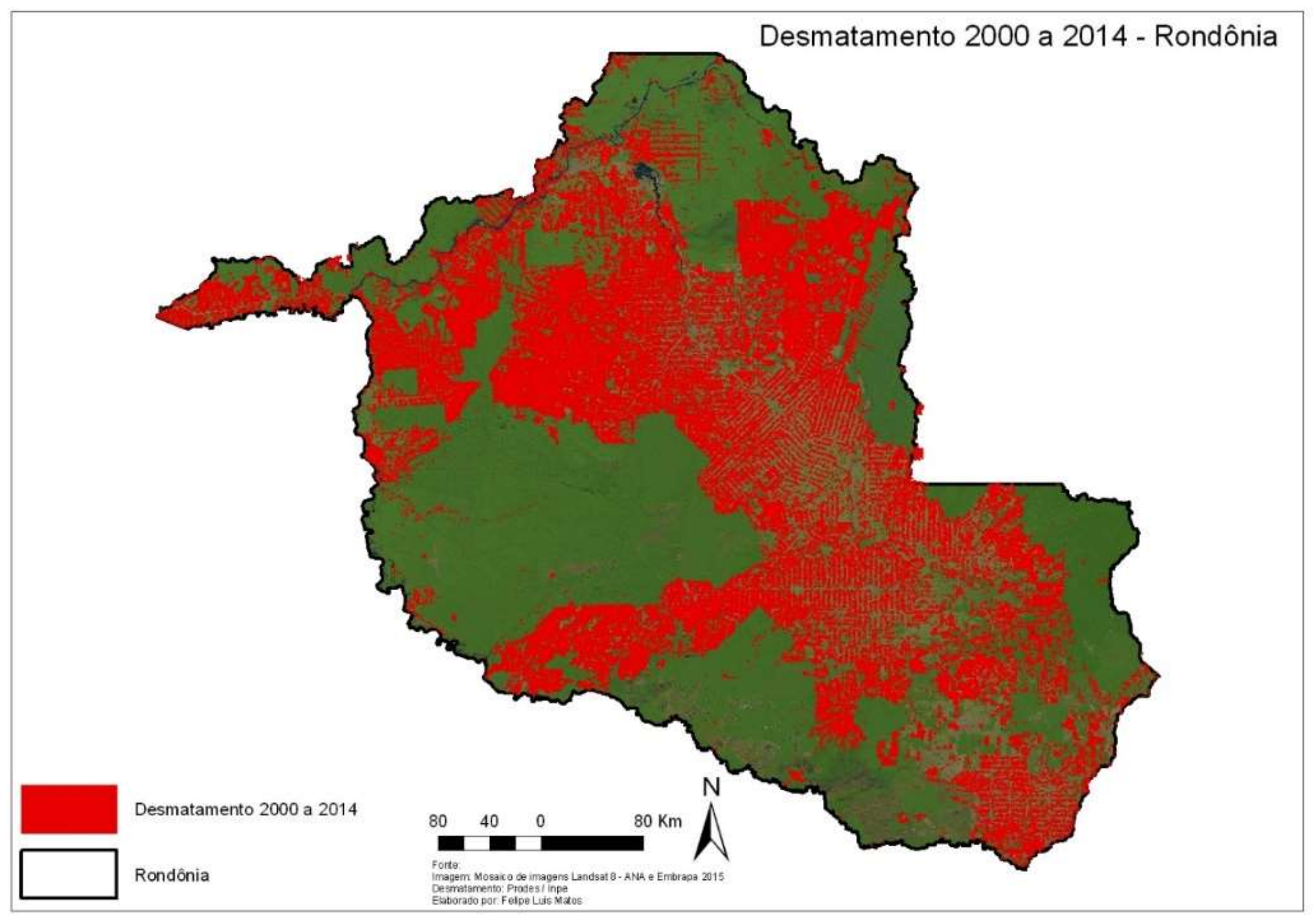

Mapa 7: Mapa do desmatamento no Estado de Rondônia. 
Conforme o Gráfico 11, no Estado de Rondônia, no período entre 2000 e 2004, antes do lançamento do PPCDAM, a taxa de desmatamento variou entre 2465 e $3858 \mathrm{~km}^{2}$, tendo seu ápice no ano de 2004. No período pós - PPCDAM, ou seja, de 2005 até 2014, a taxa de desmatamento variou entre 435 e $3244 \mathrm{~km}^{2}$, tendo seu menor valor no ano de 2010.

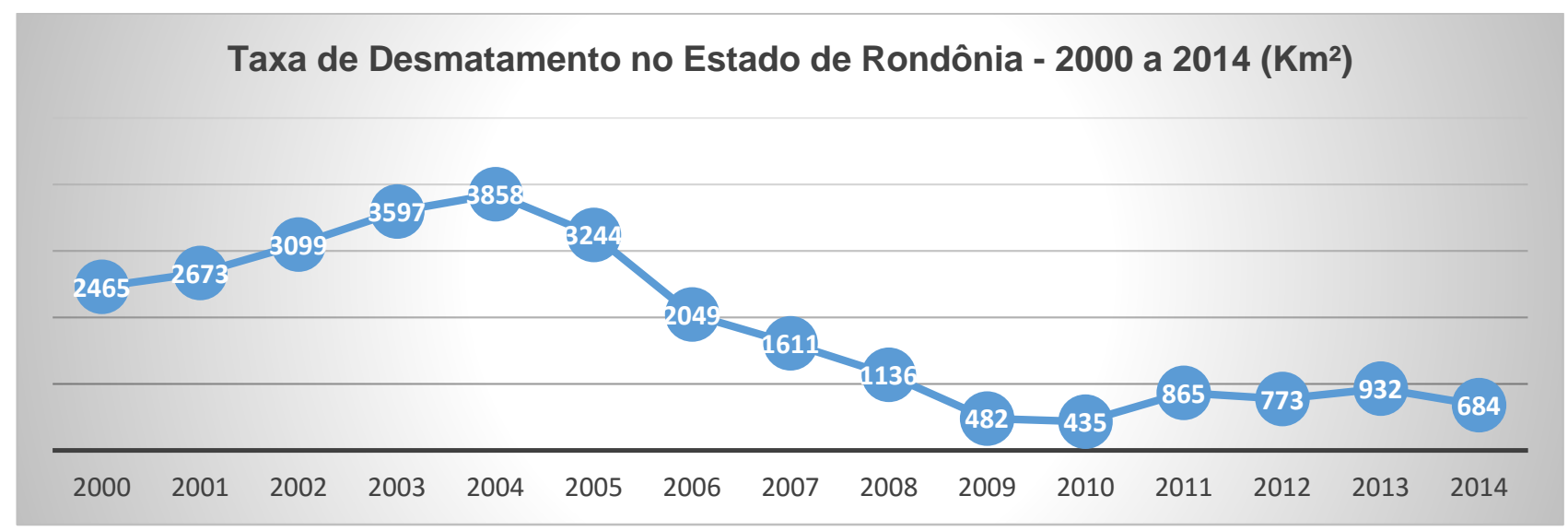

Gráfico 11: Taxa de Desmatamento no Estado de Rondônia. Fonte: PRODES/INPE

No ano de 2005, primeiro ano após o lançamento do PPCDAM, ocorreu uma queda razoável na taxa de desmatamento, de $3858 \mathrm{~km}^{2}$ para $3244 \mathrm{~km}^{2}$, isto é, uma queda de $16 \%$ em relação a 2004. A taxa continuou caindo bastante até o ano de 2010, quando ocorreu a menor taxa da história no Estado. Em 2011, a taxa de desmatamento praticamente dobrou passando de 435 para $865 \mathrm{~km}^{2}$. Teve uma pequena queda em 2012, aumentou novamente em 2013 voltando a cair em 2014. Mesmo com o grande aumento de 2011, em relação a 2010, os índices de desmatamento continuaram bem menores do que no período anterior ao PPCDAM.

No Estado de Rondônia, os projetos de infraestrutura e a abertura de estradas tem sido importantes vetores da prática do desmatamento.

Um dos motivos considerados para esse grande aumento no índice de desmatamento no período relativo a 2010-2011 foi a construção das usinas hidrelétricas de Santo Antônio e Jirau e também a discussão sobre o código florestal que acontecia na época.

Desde o início do PPCDAM, ocorreu uma diminuição considerável nos índices de desmatamento no Estado de Rondônia. Em 2005, primeiro ano do PPCDAM, a taxa de desmatamento foi de $3244 \mathrm{~km}^{2}$ e em 2014, $684 \mathrm{~km}^{2}$. Nesse período, ocorreu uma redução de 78,91\% no desmatamento no Estado de Rondônia.

Conforme o Gráfico 12, no Estado de Rondônia, no período entre 2000 e 2004, antes do lançamento do PPCDAM, a quantidade de autos de infração lavrados variou entre 738 e 1378, tendo sua menor quantidade no ano de 2002. No período pós - PPCDAM, ou seja, de 2005 até 2014, a 
quantidade de autos de infração lavrados variou entre 668 e 2069, tendo seu maior índice no ano de 2008.

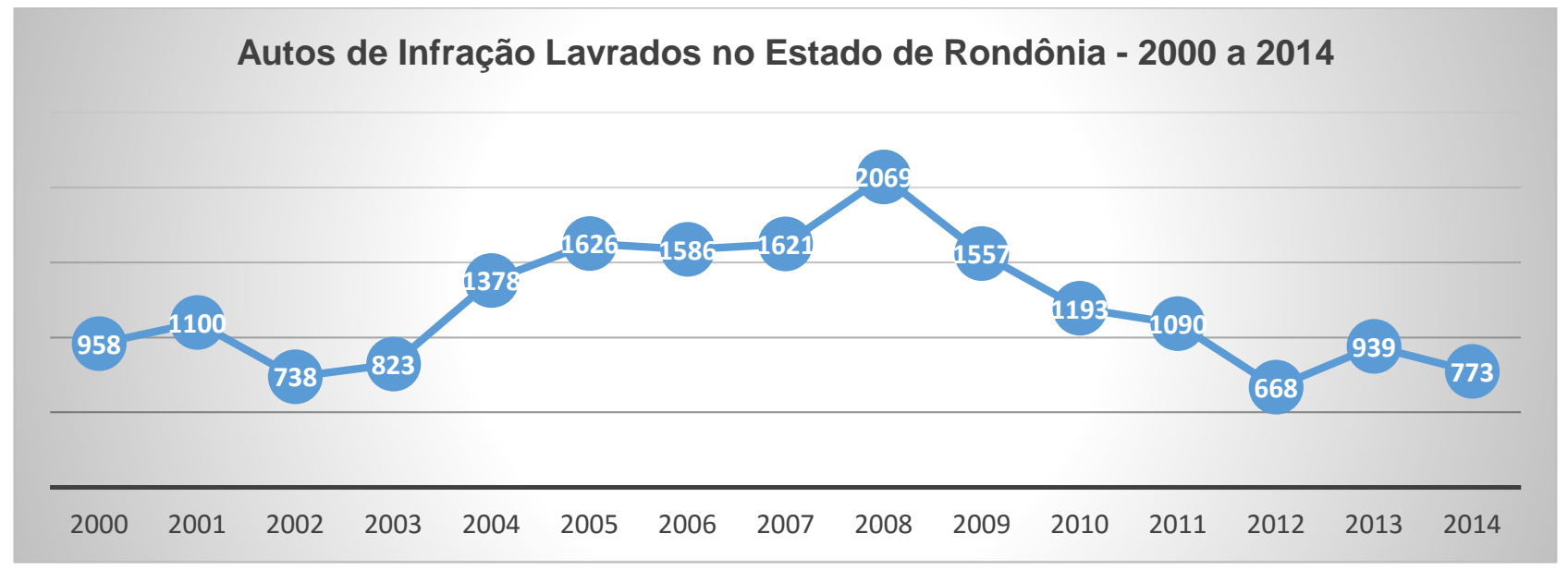

Gráfico 12: Autos de Infração Lavrados no Estado de Rondônia. Fonte: IBAMA

No ano de 2005, primeiro ano após o lançamento do PPCDAM, ocorreu um aumento de 17,99 \% na quantidade de autos de infração lavrados no Estado de Rondônia, passando de 1378 para 1626.

Em 2006, a quantidade de autos de infração foi menor que em 2005. Em 2007, houve um pequeno aumento e, em 2008, ocorreu um aumento razoável no total de autos de infração lavrados, chegando ao seu maior valor histórico. Nos anos de 2009 a 2012, a quantidade de autos de infração teve uma sequência de quedas. Em 2013, a quantidade voltou a subir e, em 2014, teve uma nova queda.

Conforme o Gráfico 13, no período entre 2000 e 2004, antes do lançamento do PPCDAM, o índice de multas por $\mathrm{km}^{2}$ variou entre 0,23 e 0,41 multas por $\mathrm{km}^{2}$, tendo seu pior desempenho no ano de 2003. No período pós - PPCDAM, ou seja, de 2005 até 2014, o índice de multas por $\mathrm{km}^{2}$ variou entre 0,50 e 3,23 multas por $\mathrm{km}^{2}$, tendo seu maior índice no ano de 2009.

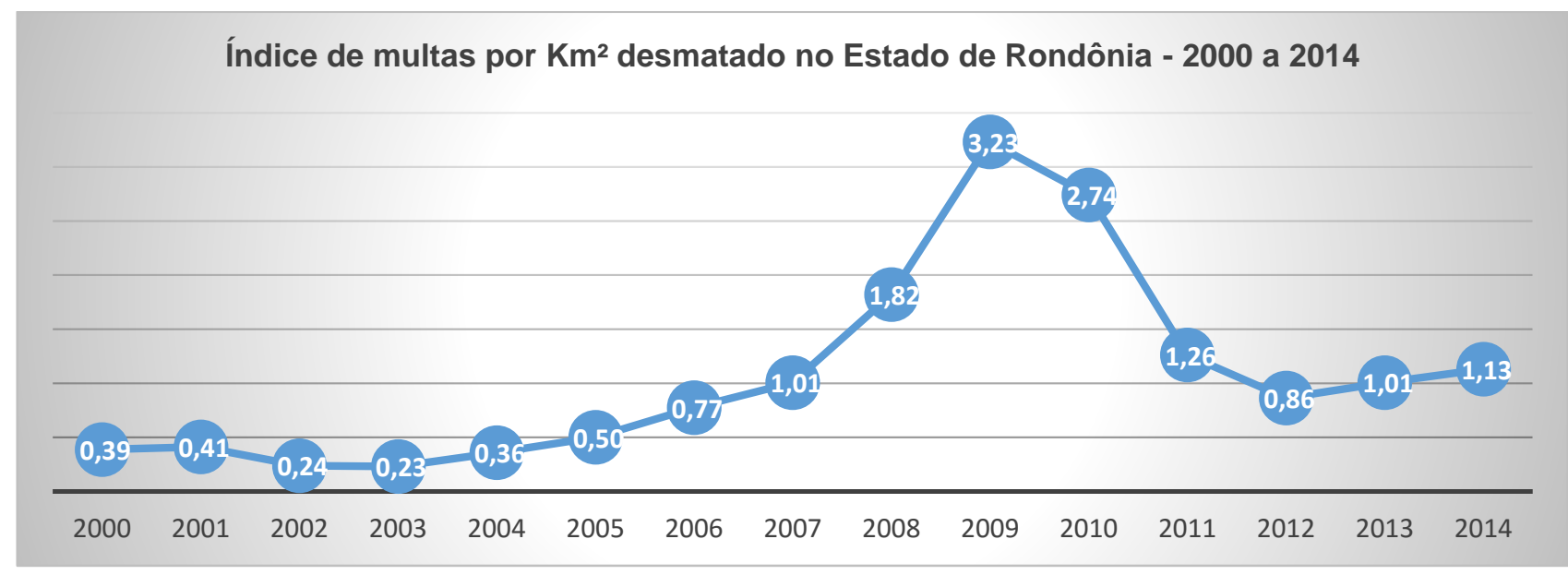


No Gráfico 13, percebemos que, no período entre 2000 e 2004, o índice tinha uma pequena variação tanto para mais quanto para menos, mas o seu valor era bem baixo.

A partir de 2005, primeiro ano efetivo do PPCDAM, ele passou a subir consideravelmente, atingindo o ápice histórico no ano de 2009. No período de 2010 a 2012, o índice teve quedas sequenciais, mas mesmo assim continuou bem acima do período anterior ao PPCDAM. Em 2013, o índice subiu novamente, fato que voltou a ocorrer em 2014. Mesmo tendo essa variação anual, a partir de 2006, os índices sempre foram bem maiores do que eram no período anterior ao PPCDAM.

A partir da análise desse índice, podemos inferir que a presença do órgão fiscalizador foi importante para a queda nos índices de desmatamento.

O índice de correlação entre as variáveis taxa de desmatamento e autos de infração lavrados foi de $-0,03$, ou seja, $r=-0,03$. Esse valor de $r$ indica que há uma relação negativa, mas bem próxima do 0 entre essas duas variáveis. Nesse caso, estatisticamente as duas variáveis não estão relacionadas.

É importante ressaltar que, após o lançamento do PPCDAM, em todos os anos, os índices de multa por $\mathrm{km}^{2}$ foram bem maiores do que no período anterior a ele.

Apesar da análise estatística mostrar que a relação entre a taxa de desmatamento e a quantidade de autos de infração lavrados, por bem pouco, não estar relacionada, o fato de, nos últimos anos, o índice de multas por $\mathrm{Km}^{2}$ ter sido bem maior do que antes do PPCDAM, nos mostra a importância da presença mais efetiva do órgão fiscalizador. Presença realizada através da adoção de medidas integradas de comando e controle no combate ao desmatamento juntamente com outros órgãos do Estado e que contribuiu para a queda na taxa de desmatamento no Estado de Rondônia. 


\subsection{Acre}

O Estado do Acre tem aproximadamente $164.123 \mathrm{~km}^{2}$ de extensão territorial. A população no Estado do Acre, segundo o IBGE, no ano de 2010 era de 733.559 habitantes (www.ibge.gov.br/estadosat).

A economia do Acre baseia-se no extrativismo vegetal, sobretudo na exploração da borracha. Atualmente, a madeira também é um produto de exportação, além de ser um grande produtor de castanha do pará, fruto do açaí e óleo de copaíba (www.ac.gov.br).

A Secretaria de Estado de Meio Ambiente do Acre (SEMA - AC) tem, como função, o planejamento, criação, execução, desenvolvimento, promoção, implementação, divulgação, monitoramento e avaliação de programas, projetos, ferramentas de gestão, leis e políticas públicas ambientais e territoriais do Estado. Em 2010, com o apoio do governo federal, lançou o Plano de Prevenção e Controle do Desmatamento do Estado do Acre (PPCD), contribuindo com o monitoramento e redução dos desmatamentos na região (www.sema.ac.gov.br).

Segue o Mapa 8 que representa o desmatamento no Estado do Acre no período entre 2000 e 2014. 


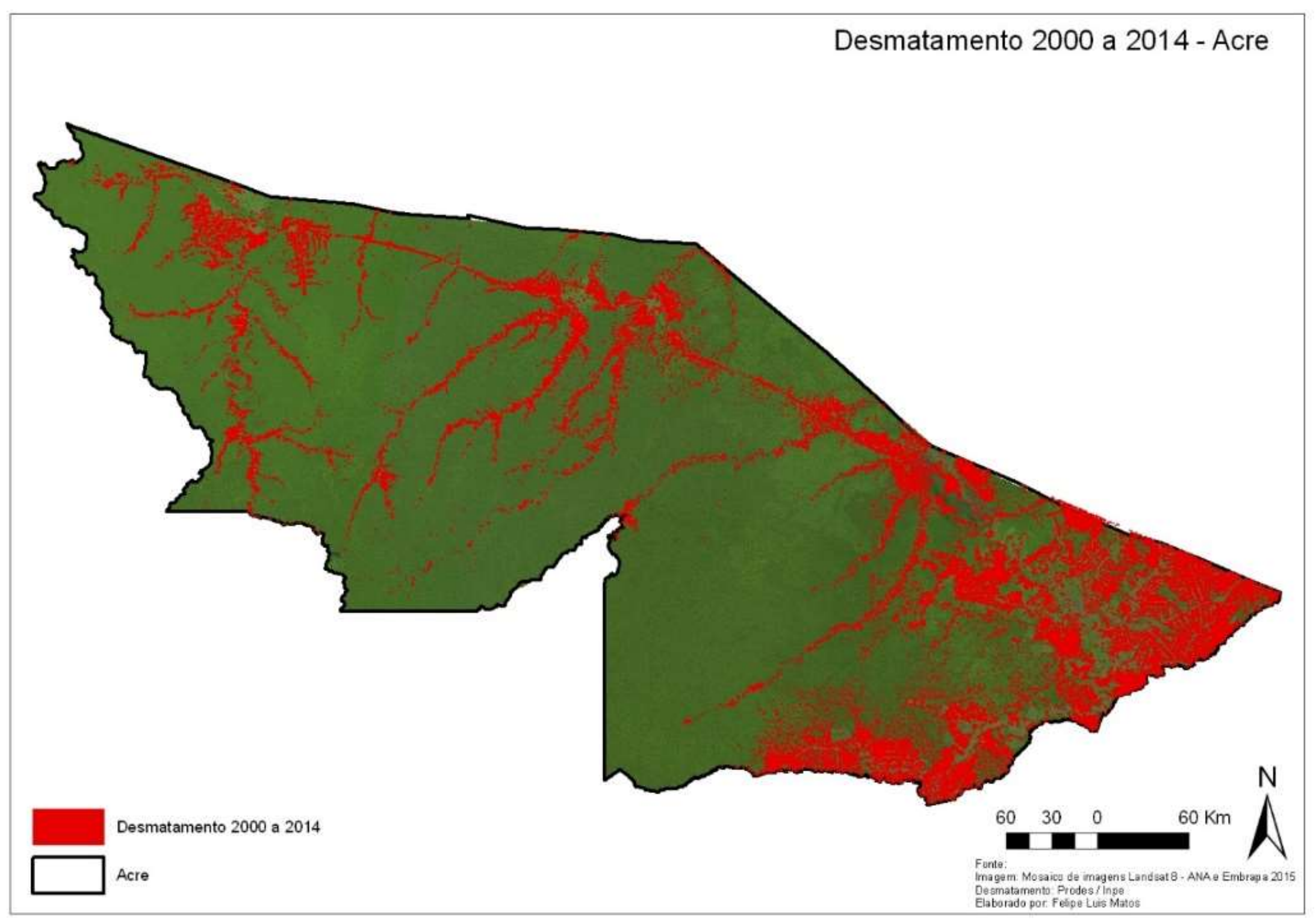

Mapa 8: Mapa do desmatamento no Estado do Acre. 
Conforme o Gráfico 14, no Estado do Acre, no período entre 2000 e 2004, antes do lançamento do PPCDAM, a taxa de desmatamento variou entre 419 e $1078 \mathrm{~km}^{2}$, tendo seu ápice no ano de 2003. No período pós - PPCDAM, ou seja, de 2005 até 2014, a taxa de desmatamento variou entre 167 e $592 \mathrm{Km}^{2}$, tendo seu menor valor no ano de 2005.

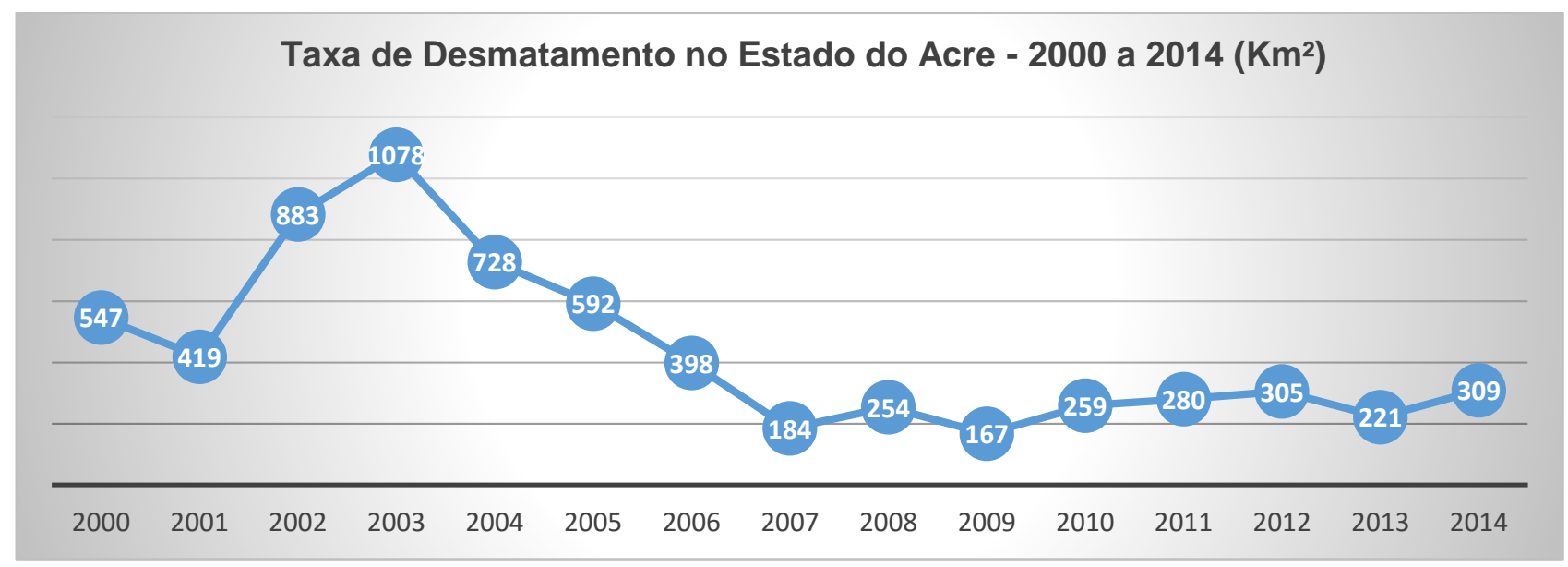

. Gráfico 14: Taxa de Desmatamento no Estado do Acre. Fonte: PRODES/INPE

No ano de 2005, primeiro ano após o lançamento do PPCDAM, ocorreu uma queda de 18,68\% na taxa de desmatamento em relação a 2004, passando de $728 \mathrm{~km}^{2}$ para $592 \mathrm{~km}^{2}$. Em 2006 e 2007, a taxa continuou caindo em relação a 2005. Em 2008, a taxa de desmatamento voltou a subir, tendo uma nova queda em 2009. De 2010 a 2012, as taxas voltaram a subir ano após ano e, em 2013, caiu novamente, tendo um novo acréscimo em 2014. Mesmo havendo o aumento das taxas de desmatamento em alguns anos, elas se mantiveram bem abaixo do período anterior ao PPCDAM.

Desde o início do PPCDAM, ocorreu uma razoável diminuição nos índices de desmatamento no Estado do Acre. Em 2005, primeiro ano do PPCDAM, a taxa de desmatamento foi de $528 \mathrm{~km}^{2} \mathrm{e}$ em 2014, 309 km². Nesse período, ocorreu uma redução de 47,8\% no desmatamento no Estado do Acre.

Conforme o Gráfico 15, no Estado do Acre, no período entre 2000 e 2004, antes do lançamento do PPCDAM, a quantidade de autos de infração lavrados variou entre 136 e 335, tendo sua menor quantidade no ano de 2000. No período pós PPCDAM, ou seja, de 2005 até 2014, a quantidade de autos de infração lavrados variou entre 67 e 946, tendo seu maior índice no ano de 2007. 


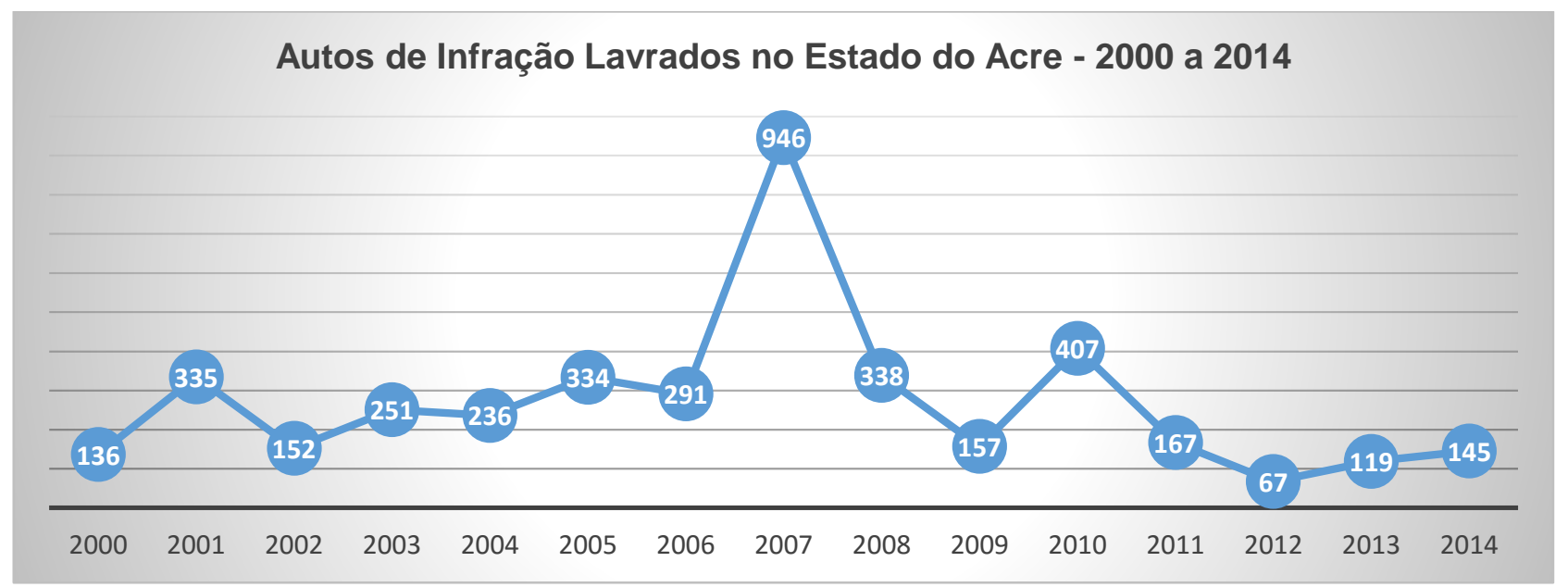

Gráfico 15: Autos de Infração Lavrados no Estado do Acre. Fonte: IBAMA

No ano de 2005, primeiro ano após o lançamento do PPCDAM, ocorreu um aumento de 41,52\% na quantidade de autos de infração lavrados no Estado do Acre, passando de 236 para 334.

Em 2006, a quantidade de autos de infração foi menor que em 2005. Em 2007, houve um grande aumento atingindo seu maior índice histórico, 946 autos de infração lavrados, seguido de uma grande queda em 2008. Em 2009, a quantidade de autos de infração voltou a cair e em 2010 subiu novamente. Em 2011 e 2012, voltou a cair novamente, movimento que se reverteu em 2013 e 2014.

Conforme o Gráfico 16, no período entre 2000 e 2004, antes do lançamento do PPCDAM, o índice de multas por $\mathrm{km}^{2}$ variou entre 0,17 e 0,80 multas por $\mathrm{km}^{2}$, tendo seu pior desempenho no ano de 2002. No período pós - PPCDAM, ou seja, de 2005 até 2014, o índice de multas por km² variou entre 0,22 e 5,14 multas por $\mathrm{km}^{2}$, tendo seu maior índice no ano de 2007.

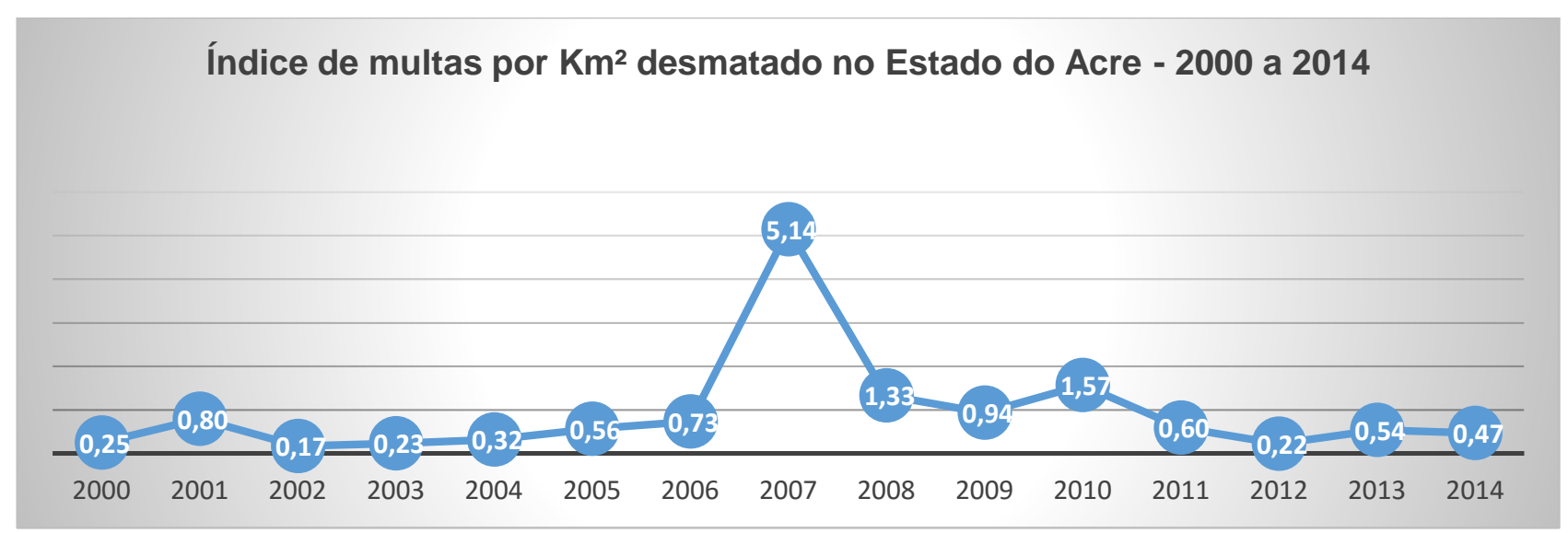

Gráfico 16: Índice de Multas por $\mathrm{Km}^{2}$ desmatado no Estado do Acre.

No Gráfico 16, percebemos que, no período entre 2000 e 2004, com exceção do ano de 2001, o índice tinha uma pequena variação tanto para mais quanto para menos e o seu valor era bem baixo. 
A partir de 2005, primeiro ano efetivo do PPCDAM, ele passou a subir consideravelmente, atingindo o ápice histórico no ano de 2007. Em 2008, houve uma queda bastante elevada no índice e, em 2009, caiu novamente, mas em menor escala. Em 2010, ele voltou a subir caindo novamente em 2011 e 2012, ano em que atingiu valor parecido com os anteriores ao PPCDAM. No período anterior ao PPCDAM, o ano de 2001 foi bem diferente dos outros anos, tendo um valor bem alto e, no período posterior ao PPCDAM, o ano de 2012 teve um valor bem inferior aos outros anos.

O índice de correlação entre as variáveis taxa de desmatamento e autos de infração lavrados foi de $-0,20$, ou seja, $r=-0,20$. Esse valor de $r$ indica que há uma relação negativa entre essas duas variáveis, ou seja, elas estatisticamente se movem de forma oposta.

A análise estatística mostra que a relação entre a taxa de desmatamento e a quantidade de autos de infração lavrados é negativa, ou seja, não está relacionada. A taxa de desmatamento apresentou queda de 2004 a 2007 e depois disso veio tendo mais aumentos anuais do que quedas nos anos posteriores. No Estado do Acre, com exceção do ano de 2007, quando ocorreu uma explosão na quantidade de autos de infração lavrados, em geral no período pré - PPCDAM e pós - PPCDAM, não houve uma grande diferença na quantidade de autuações. Mesmo não havendo essa relação estatística, o desmatamento no Acre caiu consideravelmente após a implantação do PPCDAM. 


\subsection{Amazonas}

O Estado do Amazonas tem aproximadamente 1.559.149 $\mathrm{km}^{2}$ de extensão territorial. A população no Estado do Amazonas, segundo o IBGE, no ano de 2010 era de 3.483.985 habitantes (www.ibge.gov.br/estadosat).

A economia do Amazonas se baseia no Polo Industrial de Manaus (PIM) que é um modelo de desenvolvimento regional que abriga inúmeras empresas nacionais e internacionais, concedendo incentivos fiscais para a produção. Além disso, busca o desenvolvimento de atividades voltadas ao aproveitamento de recursos naturais nas áreas de agroindústria, bioindústria, fruticultura, turismo, energia, dentre outras potencialidades abundantes na região (www.amazonas.am.gov.br).

Como autarquia vinculada à Secretaria de Estado do Meio Ambiente e Desenvolvimento Sustentável do Amazonas (SDS - AM), existe o Instituto de Proteção Ambiental do Amazonas (IPAAM) que tem, como principais atividades, o licenciamento, fiscalização e monitoramento ambiental （www.amazonas.am.gov.br/entidade/instituto-de-protecao-ambiental-do-amazonasipaam).

Segue o Mapa 9 que representa o desmatamento no Estado do Amazonas no período entre 2000 e 2014. 


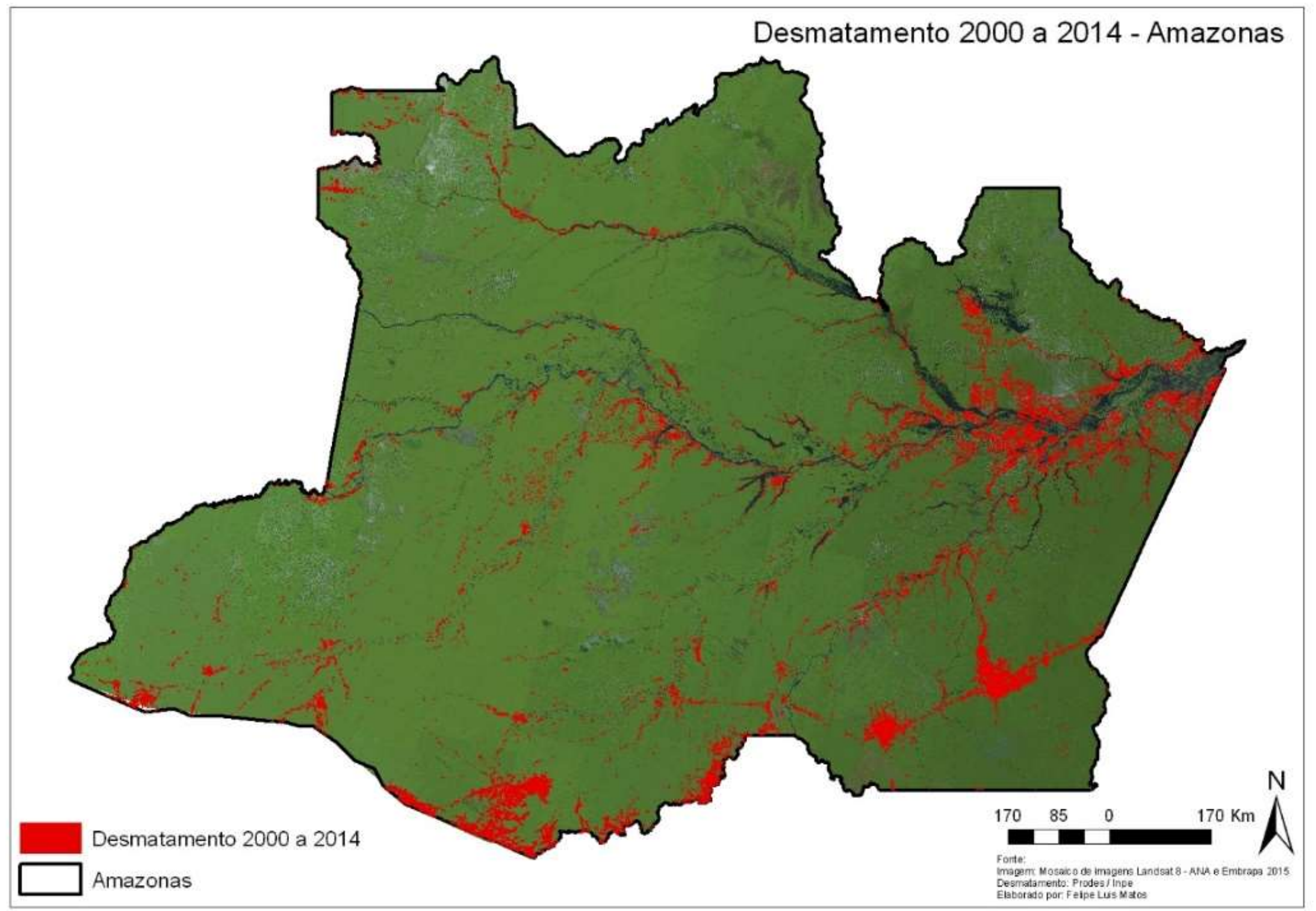

Mapa 9: Mapa do desmatamento no Estado do Amazonas. 
Conforme o Gráfico 17, no Estado do Amazonas, no período entre 2000 e 2004, antes do lançamento do PPCDAM, a taxa de desmatamento variou entre 612 e $1558 \mathrm{~km}^{2}$, tendo seu ápice no ano de 2003. No período pós - PPCDAM, ou seja, de 2005 até 2014, a taxa de desmatamento variou entre 405 e $788 \mathrm{~km}^{2}$, tendo seu menor valor no ano de 2009.

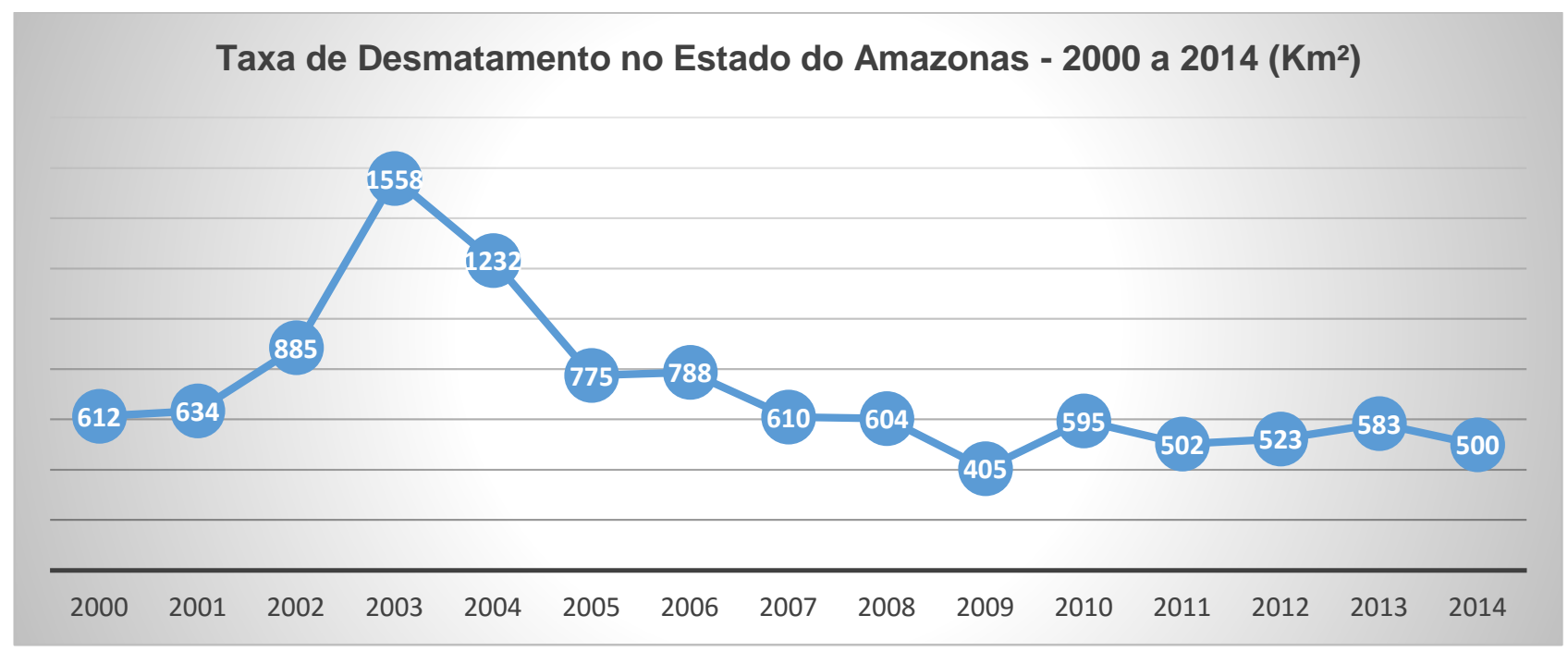

Gráfico 17: Taxa de Desmatamento no Estado do Amazonas. Fonte: PRODES/INPE

No ano de 2005, primeiro ano após o lançamento do PPCDAM, ocorreu uma queda de 37,09\% na taxa de desmatamento em relação a 2004, passando de $1232 \mathrm{~km}^{2}$ para $775 \mathrm{~km}^{2}$. Em 2006, a taxa subiu um pouco em relação a 2005. De 2007 a 2009, a taxa seguiu caindo, tendo atingido seu menor valor histórico em 2009. Em 2010, a taxa de desmatamento voltou a subir, tendo uma nova queda em 2011. Em 2012 e 2013, a taxa voltou a subir e, em 2014, caiu novamente.

Desde o início do PPCDAM, ocorreu uma considerável diminuição nos índices de desmatamento no Estado do Amazonas. Em 2005, primeiro ano do PPCDAM, a taxa de desmatamento foi de $1232 \mathrm{~km}^{2}$ e em $2014,500 \mathrm{~km}^{2}$. Nesse período, ocorreu uma redução de 59,41\% no desmatamento no Estado do Amazonas.

Conforme o Gráfico 18, no Estado do Amazonas, no período entre 2000 e 2004, antes do lançamento do PPCDAM, a quantidade de autos de infração lavrados variou entre 226 e 472, tendo sua menor quantidade no ano de 2000. No período pós PPCDAM, ou seja, de 2005 até 2014, a quantidade de autos de infração lavrados variou entre 334 e 712, tendo seu maior índice no ano de 2007. 


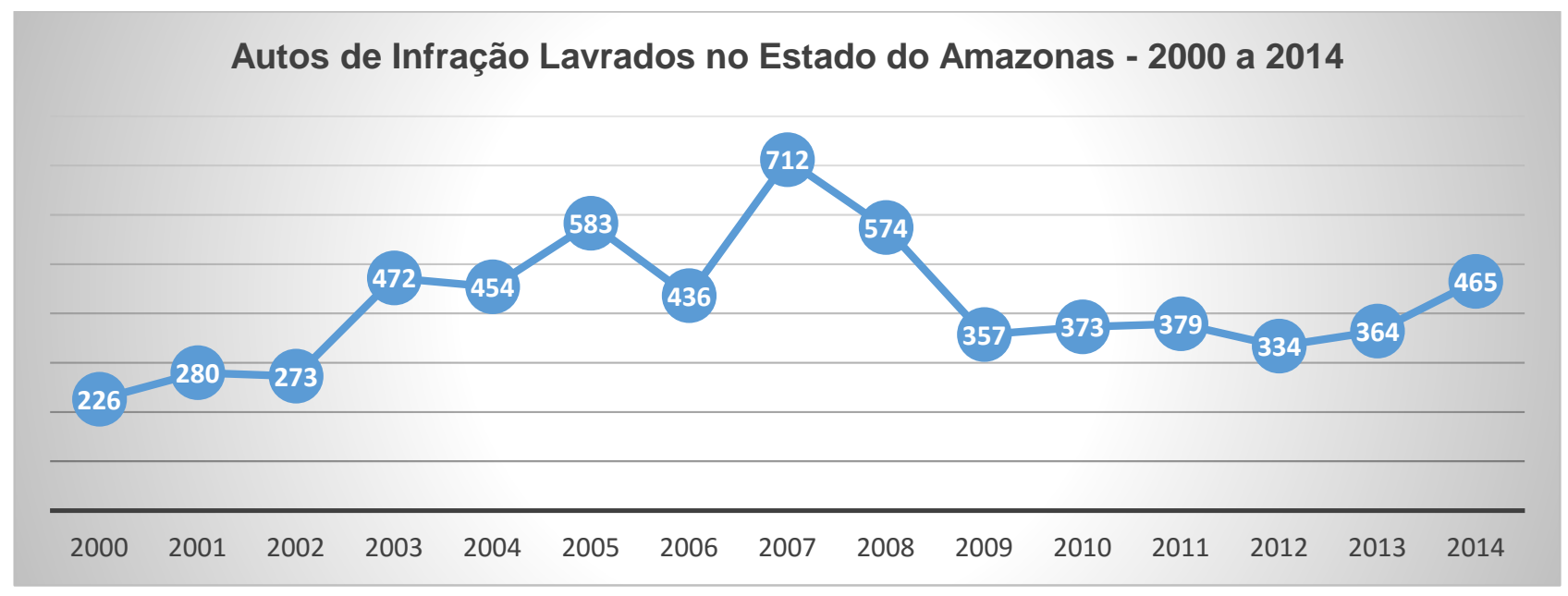

Gráfico 18: Autos de Infração Lavrados no Estado do Amazonas. Fonte: IBAMA

No ano de 2005, primeiro ano após o lançamento do PPCDAM, ocorreu um aumento de 28,41\% na quantidade de autos de infração lavrados no Estado do Amazonas, passando de 454 para 583.

Em 2006, a quantidade de autos de infração foi menor que em 2005. Em 2007, houve um grande aumento, atingindo seu maior índice histórico, 712 autos de infração lavrados, seguido de queda em 2008 e 2009. Em 2010 e 2011, a quantidade de autos de infração voltou a subir. Em 2012, caiu novamente e, em 2013 e 2014, voltou a subir.

Conforme o Gráfico 19, no período entre 2000 e 2004, antes do lançamento do PPCDAM, o índice de multas por $\mathrm{km}^{2}$ variou entre 0,30 e 0,44 multas por $\mathrm{km}^{2}$, tendo seu pior desempenho no ano de 2003. No período pós - PPCDAM, ou seja, de 2005 até 2014, o índice de multas por km² variou entre 0,55 e 1,17 multas por $\mathrm{km}^{2}$, tendo seu maior índice no ano de 2007.

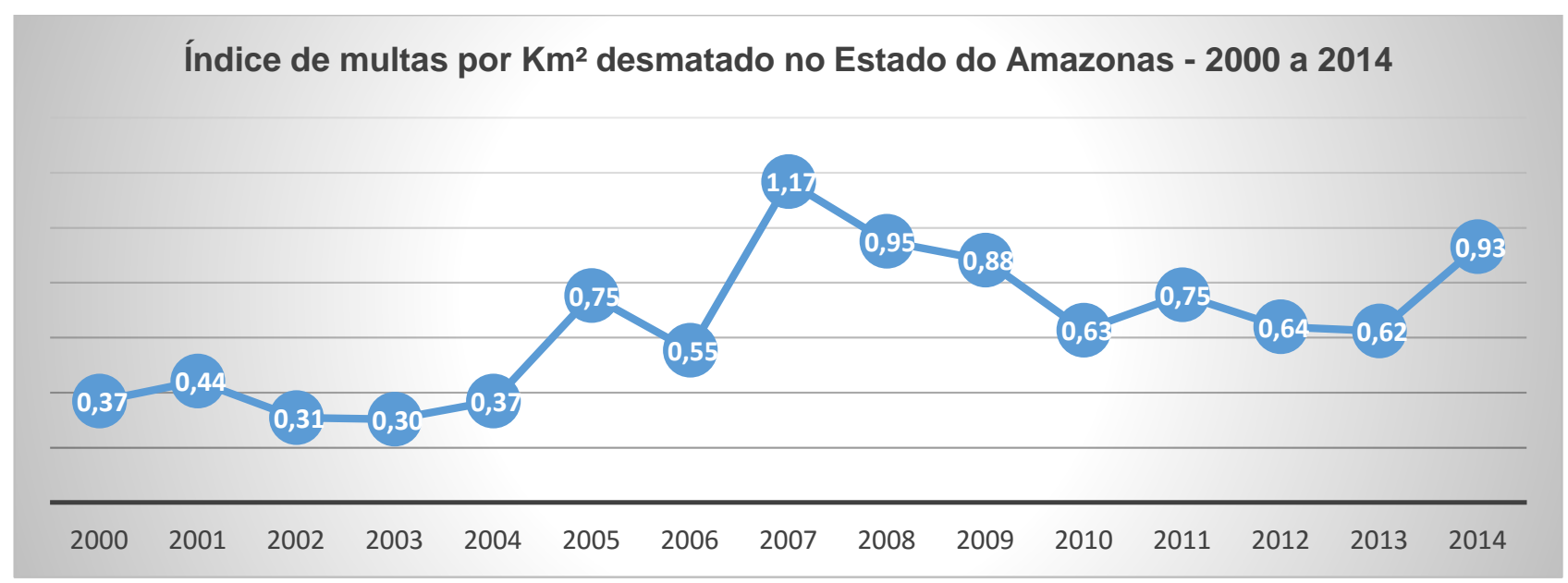

Gráfico 19: Índice de Multas por $\mathrm{Km}^{2}$ desmatado no Estado do Amazonas. 
No Gráfico 19, percebemos que, no período entre 2000 e 2004, o índice tinha uma pequena variação tanto para mais quanto para menos e o seu valor era bem baixo.

Em 2005, primeiro ano efetivo do PPCDAM, ele mais que dobrou em relação ao ano anterior e, em 2006, caiu. Em 2007, subiu consideravelmente, atingindo o seu ápice histórico. De 2008 a 2010, foram anos de sucessivas quedas, voltando a subir em 2011. Em 2012 e 2013, o índice caiu novamente e, em 2014, voltou a subir de modo considerável. Mesmo tendo essa variação anual, a partir de 2005, os índices sempre foram bem maiores do que eram no período anterior ao PPCDAM.

A partir da análise desse índice, podemos inferir que a presença do órgão fiscalizador foi importante para a queda nos índices de desmatamento.

O índice de correlação entre as variáveis taxa de desmatamento e autos de infração lavrados foi de 0,14 , ou seja, $r=0,14$. Esse valor de $r$ indica que há uma relação positiva.

É importante ressaltar que, após o lançamento do PPCDAM, em todos os anos, os índices de multa por $\mathrm{km}^{2}$ foram bem maiores do que no período anterior a ele.

A partir da análise do índice de multas por $\mathrm{km}^{2}$, podemos inferir que a presença mais efetiva do órgão fiscalizador, juntamente com adoção de medidas integradas de comando e controle entre diversos órgãos do Estado, após o lançamento do PPCDAM, foi importante para a queda nos índices de desmatamento no Estado do Amazonas.

\subsection{Maranhão}

O Estado do Maranhão tem aproximadamente $331.937 \mathrm{~km}^{2}$ de extensão territorial. A população no Estado do Maranhão, segundo o IBGE, no ano de 2010 era de 6.574 .789 habitantes (www.ibge.gov.br/estadosat).

A economia do Maranhão é baseada nos setores metalúrgico, madeireiro, extrativismo, químico, pesca e no turismo.

A Secretaria de Meio Ambiente do Maranhão (SEMA - MA) lançou no ano de 2016, o Sistema Nacional de Controle da Origem dos Produtos Florestais (SENAFLOR) que tem, como finalidade, controlar a origem da madeira, do carvão e de outros produtos e subprodutos florestais, além de consolidar os respectivos dados dos diferentes entes federativos numa só plataforma (http://www.sema.ma.gov.br/site/noticias?id=243).

Segue o Mapa 10 que representa o desmatamento no Estado do Maranhão no período entre 2000 e 2014. 


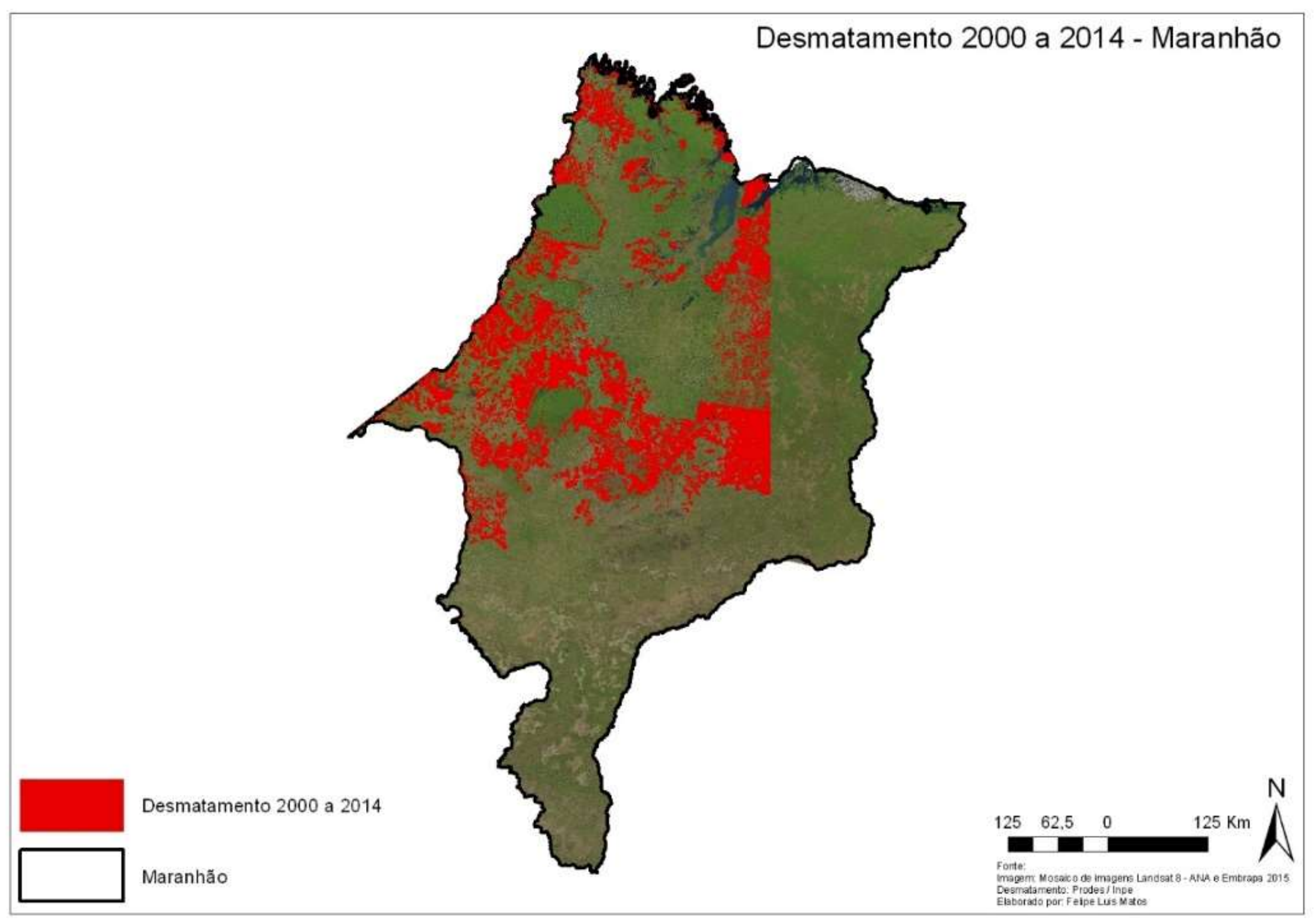

Mapa 10: Mapa do desmatamento no Estado do Maranhão. 
Conforme o Gráfico 20, no Estado do Maranhão, no período entre 2000 e 2004, antes do lançamento do PPCDAM, a taxa de desmatamento variou entre 755 e $1085 \mathrm{~km}^{2}$, tendo seu ápice no ano de 2002. No período pós - PPCDAM, ou seja, de 2005 até 2014, a taxa de desmatamento variou entre 257 e $1271 \mathrm{~km}^{2}$, tendo seu menor valor no ano de 2014.

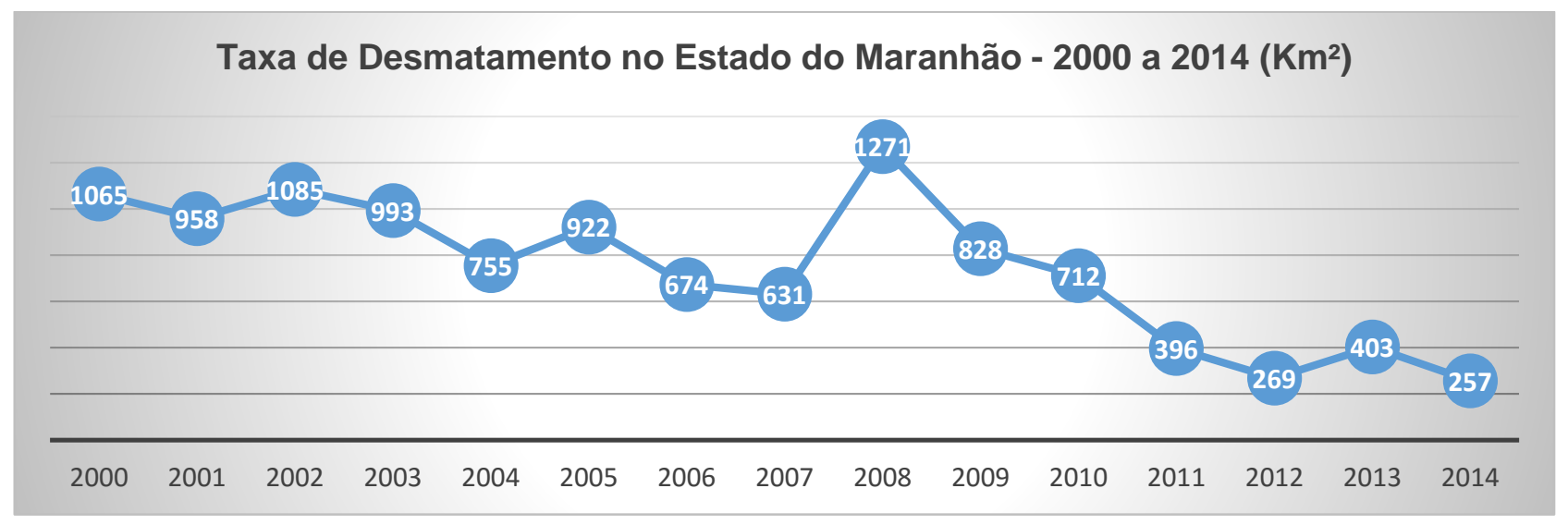

Gráfico 20: Taxa de Desmatamento no Estado do Maranhão. Fonte: PRODES/INPE

No ano de 2005, primeiro ano após o lançamento do PPCDAM, ocorreu um aumento de 22,12\% na taxa de desmatamento em relação a 2004, passando de $755 \mathrm{~km}^{2}$ para $922 \mathrm{~km}^{2}$. Em $2006 \mathrm{e}$ 2007, a taxa caiu bastante em relação a 2005. Em 2008, a taxa explodiu em relação a 2007 tendo um aumento de $101,42 \%$, passando de $631 \mathrm{~km}^{2}$ para $1271 \mathrm{~km}^{2}$. De 2009 a 2012, a taxa de desmatamento passou a cair consideravelmente. Em 2013, a taxa voltou a subir novamente. Em 2014, houve uma nova queda e foi o ano em que atingiu seu menor índice histórico.

Desde o início do PPCDAM, ocorreu uma grande diminuição nos índices de desmatamento no Estado do Maranhão. Em 2005, primeiro ano do PPCDAM, a taxa de desmatamento foi de 922 $\mathrm{km}^{2}$ e em 2014, $257 \mathrm{~km}^{2}$. Nesse período ocorreu uma redução de 72,12\% no desmatamento no Estado do Maranhão.

Conforme o Gráfico 21, no Estado do Maranhão, no período entre 2000 e 2004, antes do lançamento do PPCDAM, a quantidade de autos de infração lavrados variou entre 228 e 387, tendo sua menor quantidade no ano de 2004. No período pós - PPCDAM, ou seja, de 2005 até 2014, a quantidade de autos de infração lavrados variou entre 141 e 854 , tendo seu maior índice no ano de 2006. 


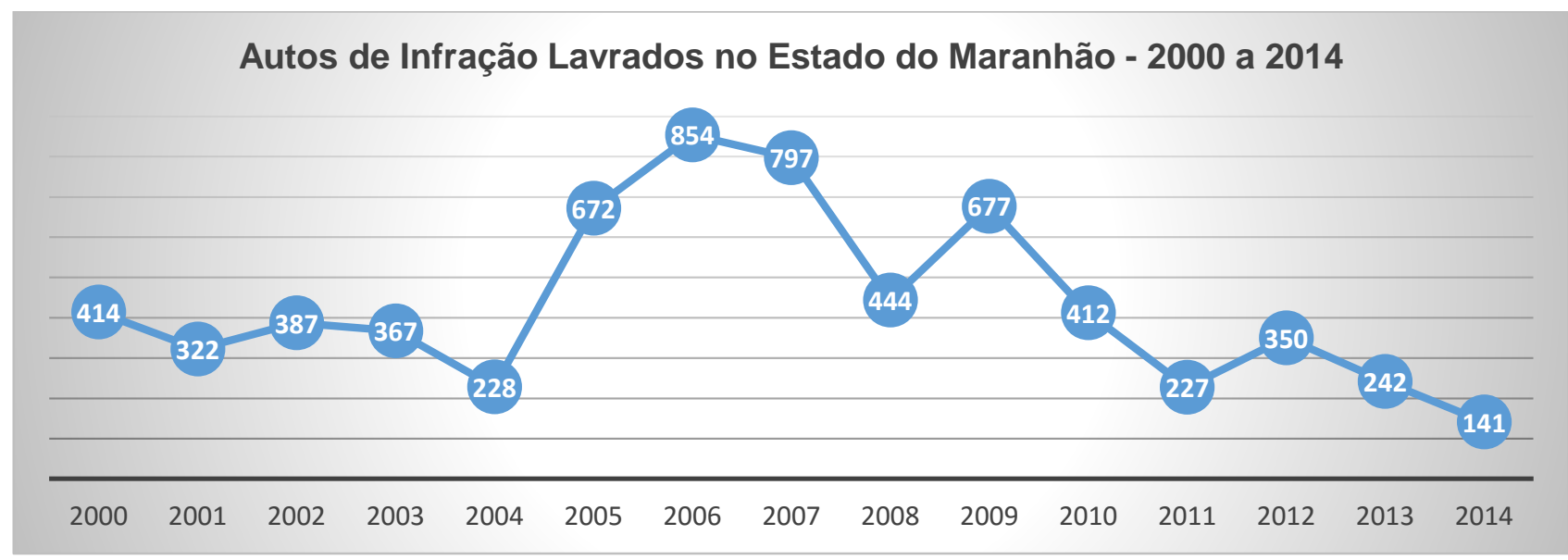

Gráfico 21: Autos de Infração Lavrados no Estado do Maranhão. Fonte: IBAMA

No ano de 2005, primeiro ano após o lançamento do PPCDAM, ocorreu um aumento de 194,74\% na quantidade de autos de infração lavrados no Estado do Maranhão, passando de 228 para 672.

Em 2006, a quantidade de autos de infração foi maior que em 2005. Em 2007 e 2008, caiu em relação a 2006, voltando a subir em 2009. Em 2010 e 2011, a quantidade de autos de infração voltou a cair. Em 2012, subiu novamente e, em 2013 e 2014, voltou a cair.

Conforme o Gráfico 22, no período entre 2000 e 2004, antes do lançamento do PPCDAM, o índice de multas por $\mathrm{km}^{2}$ variou entre 0,30 e 0,39 multas por $\mathrm{km}^{2}$, tendo seu pior desempenho no ano de 2004. No período pós - PPCDAM, ou seja, de 2005 até 2014, o índice de multas por km² variou entre 0,35 e 1,30 multas por $\mathrm{km}^{2}$, tendo seu maior índice no ano de 2012.

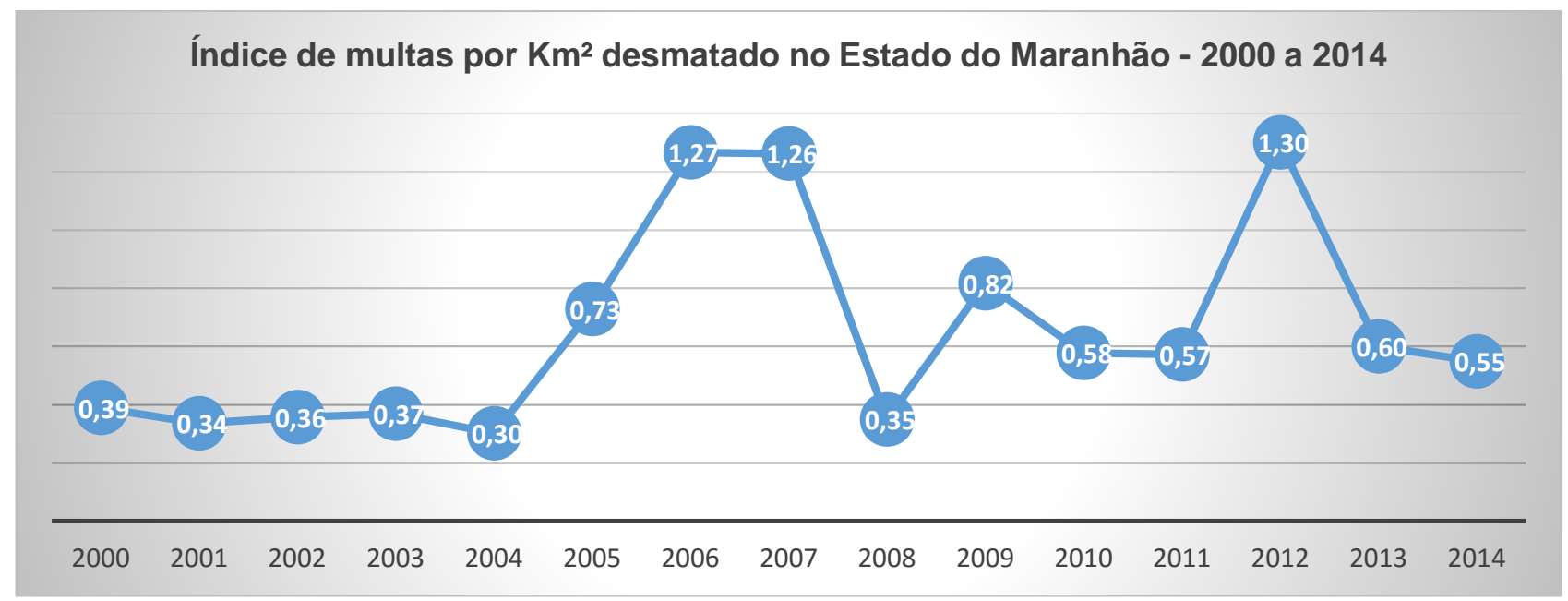

Gráfico 22: Índice de Multas por $\mathrm{Km}^{2}$ desmatado no Estado do Maranhão.

No Gráfico 22, percebemos que, no período entre 2000 e 2004, o índice tinha uma pequena variação tanto para mais quanto para menos e o seu valor era bem baixo. 
Em 2005 e 2006, ele teve dois aumentos consideráveis em relação a 2004. Em 2007, ele foi praticamente igual a 2006. Em 2008, o índice caiu bastante atingindo um valor semelhante ao período anterior ao PPCDAM. Em 2009, houve novamente um grande aumento e, em 2010, caiu novamente, mas em menor escala. Em 2011, foi praticamente igual a 2010. Em 2012, teve novamente um grande aumento que foi seguido de uma enorme queda em 2013. Em 2014, ocorreu uma pequena queda. Mesmo tendo essa variação anual, a partir de 2005, os índices sempre foram, com exceção do ano de 2008, bem maiores do que eram no período anterior ao PPCDAM.

O índice de correlação entre as variáveis taxa de desmatamento e autos de infração lavrados foi de 0,26 , ou seja, $r=0,26$. Esse valor de $r$ indica que há uma relação positiva entre essas duas variáveis, ou seja, elas se movem de forma conjunta.

É importante ressaltar que, após o lançamento do PPCDAM, em todos os anos, com exceção do ano de 2008, os índices de multa por $\mathrm{km}^{2}$ foram maiores do que no período anterior a ele.

A partir da análise do índice de multas por $\mathrm{km}^{2}$, podemos inferir que a presença mais efetiva do órgão fiscalizador juntamente com adoção de medidas integradas de comando e controle entre diversos órgãos do Estado, após o lançamento do PPCDAM, foram importantes para a queda nos índices de desmatamento no Estado do Maranhão.

\subsection{Tocantins}

O Estado do Tocantins tem aproximadamente $277.720 \mathrm{~km}^{2}$ de extensão territorial. A população no Estado do Tocantins, segundo o IBGE, no ano de 2010 era de 1.383.445 habitantes (www.ibge.gov.br/estadosat).

A economia do Tocantins é baseada na agropecuária e na mineração.

A Secretaria de Meio Ambiente e Recursos Hídricos do Tocantins (SEMARH - TO) tem, como função, planejar, coordenar e acompanhar as políticas estaduais de recursos hídricos, meio ambiente, produção de energias limpas, preservação, conservação e utilização sustentável de ecossistemas, biodiversidade e florestas do Estado do Tocantins. Dentro da estrutura da secretaria, existe a Diretoria de Desenvolvimento Sustentável e Meio Ambiente que engloba a Coordenadoria de Políticas Florestais que tem, como um de seus objetivos, acompanhar a dinâmica do desmatamento no Estado do Tocantins, através do monitoramento de coberturas vegetais. (www.semarh.to.gov.br/secretaria/objetivos).

Segue o Mapa 11 que representa o desmatamento no Estado do Tocantins no período entre 2000 e 2014. 


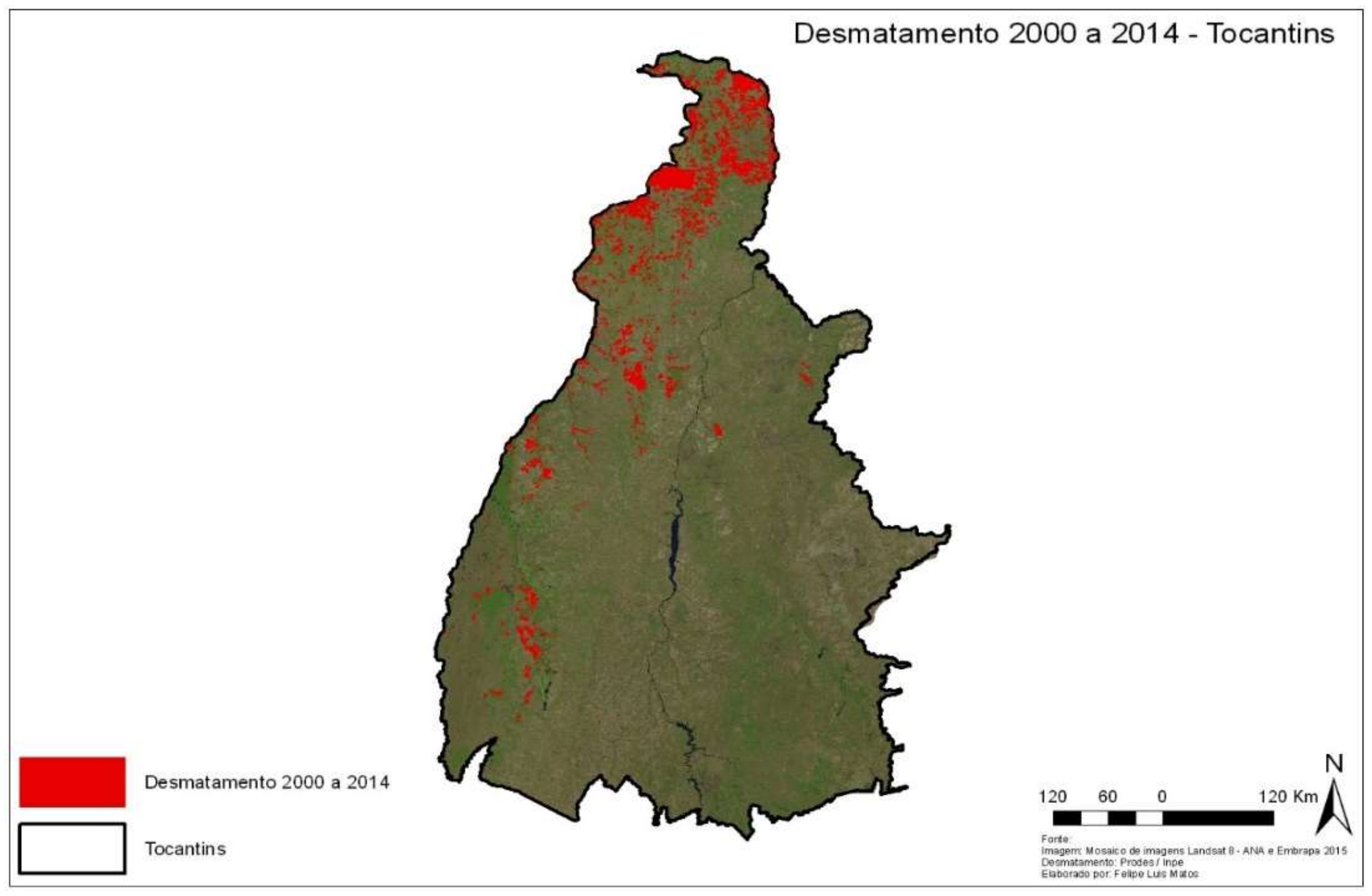

Mapa 11: Mapa do desmatamento no Estado do Tocantins. 
Conforme o Gráfico 23, no Estado do Tocantins, no período entre 2000 e 2004, antes do lançamento do PPCDAM, a taxa de desmatamento variou entre 156 e $244 \mathrm{~km}^{2}$, tendo seu ápice no ano de 2000. No período pós - PPCDAM, ou seja, de 2005 até 2014, a taxa de desmatamento variou entre 271 e $40 \mathrm{~km}^{2}$, tendo seu menor valor no ano de 2011.

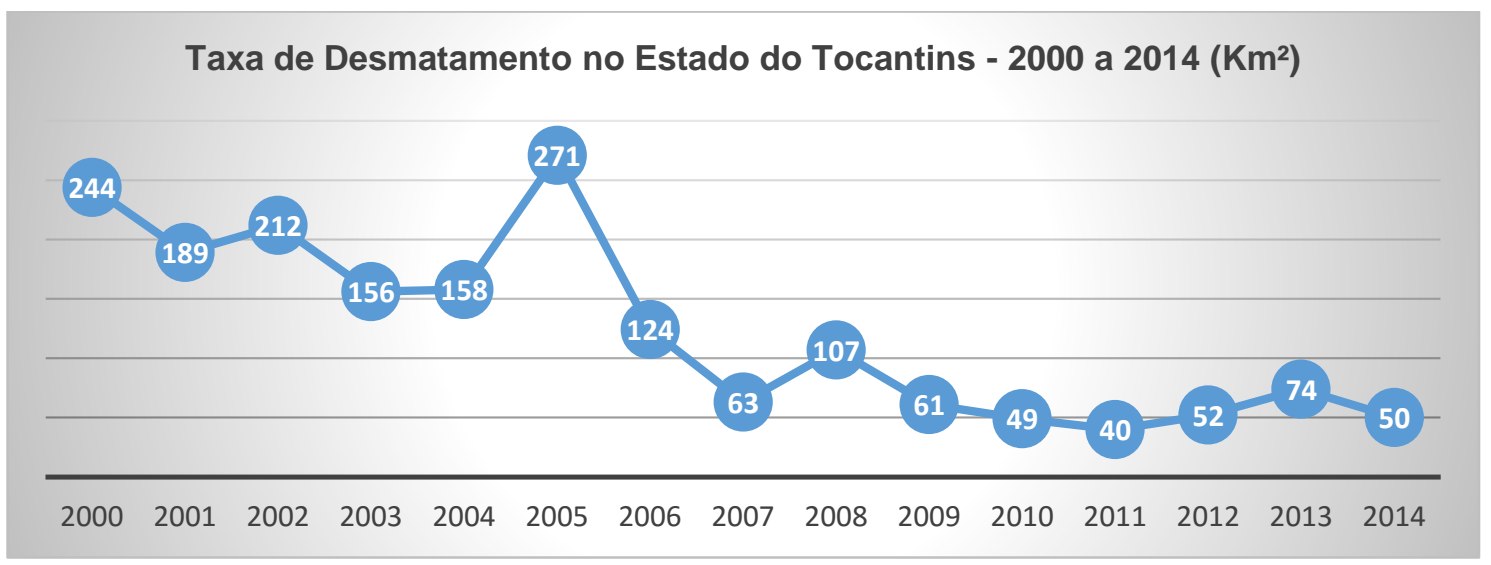

Gráfico 23: Taxa de Desmatamento no Estado do Tocantins. Fonte: PRODES/INPE

No ano de 2005, primeiro ano após o lançamento do PPCDAM, ocorreu um aumento de $71,51 \%$ na taxa de desmatamento em relação a 2004, passando de $158 \mathrm{~km}^{2}$ para $271 \mathrm{~km}^{2}$. Em 2006 e 2007, a taxa caiu bastante em relação a 2005. Em 2008, a taxa voltou a subir. De 2009 a 2011, a taxa de desmatamento teve uma sequência de quedas. Em 2013, a taxa voltou a subir novamente e, em 2014, a taxa de desmatamento voltou a cair.

Desde o início do PPCDAM, ocorreu uma considerável diminuição nos índices de desmatamento no Estado do Tocantins. Em 2005, primeiro ano do PPCDAM, a taxa de desmatamento foi de $271 \mathrm{~km}^{2}$ e em 2014, $50 \mathrm{~km}^{2}$. Nesse período, ocorreu uma redução de $81,55 \%$ no desmatamento no Estado do Tocantins.

Conforme o Gráfico 24, no Estado do Tocantins, no período entre 2000 e 2004, antes do lançamento do PPCDAM, a quantidade de autos de infração lavrados variou entre 218 e 444, tendo sua menor quantidade no ano de 2000. No período pós - PPCDAM, ou seja, de 2005 até 2014, a quantidade de autos de infração lavrados variou entre 170 e 351, tendo seu maior índice no ano de 2010. 


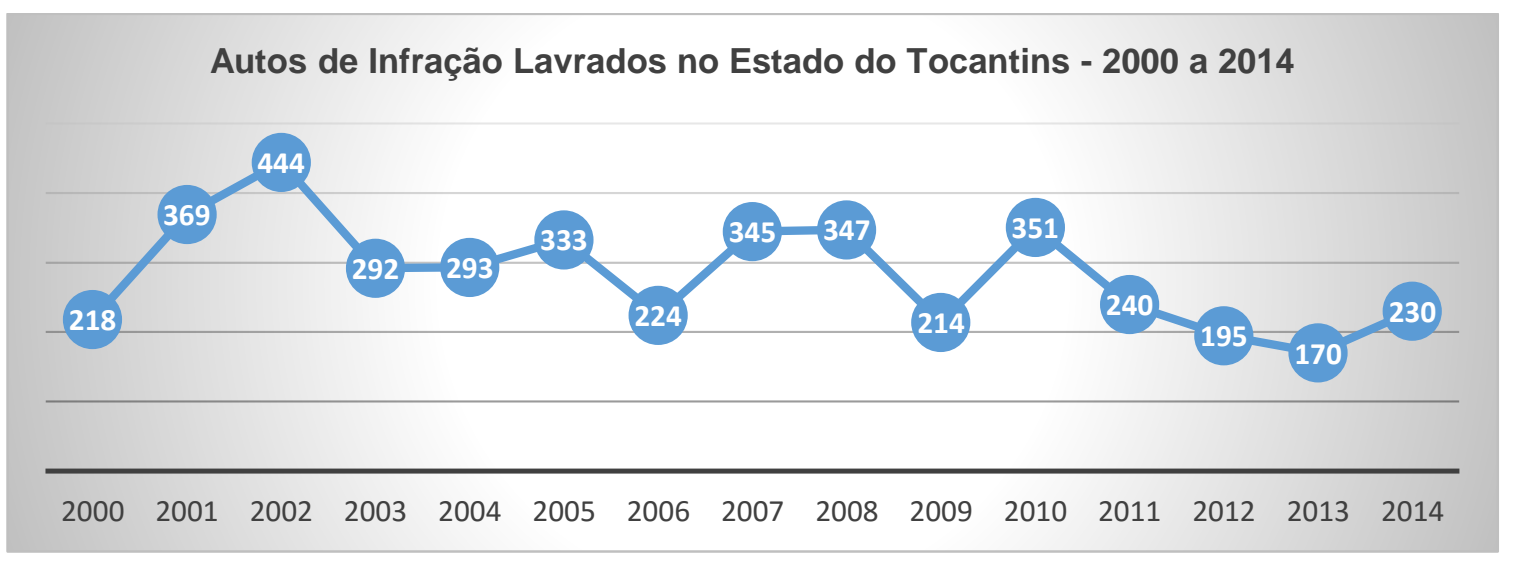

Gráfico 24: Autos de Infração Lavrados no Estado do Tocantins. Fonte: IBAMA

No ano de 2005, primeiro ano após o lançamento do PPCDAM, ocorreu um aumento de 13,65\% na quantidade de autos de infração lavrados no Estado do Tocantins, passando de 293 para 333.

Em 2006, a quantidade de autos de infração foi menor que em 2005. Em 2007 e 2008, subiu em relação a 2006, voltando a cair em 2009. Em 2010, a quantidade de autos de infração subiu novamente. Em 2011, 2012 e 2013, ocorreu uma sequência de quedas e voltou a subir em 2014.

Conforme o Gráfico 25, no período entre 2000 e 2004, antes do lançamento do PPCDAM, o índice de multas por $\mathrm{km}^{2}$ variou entre 0,89 e 2,09 multas por $\mathrm{km}^{2}$, tendo seu pior desempenho no ano de 2000. No período pós - PPCDAM, ou seja, de 2005 até 2014, o índice de multas por $\mathrm{km}^{2}$ variou entre 1,23 e 7,16 multas por $\mathrm{km}^{2}$, tendo seu maior índice no ano de 2010.

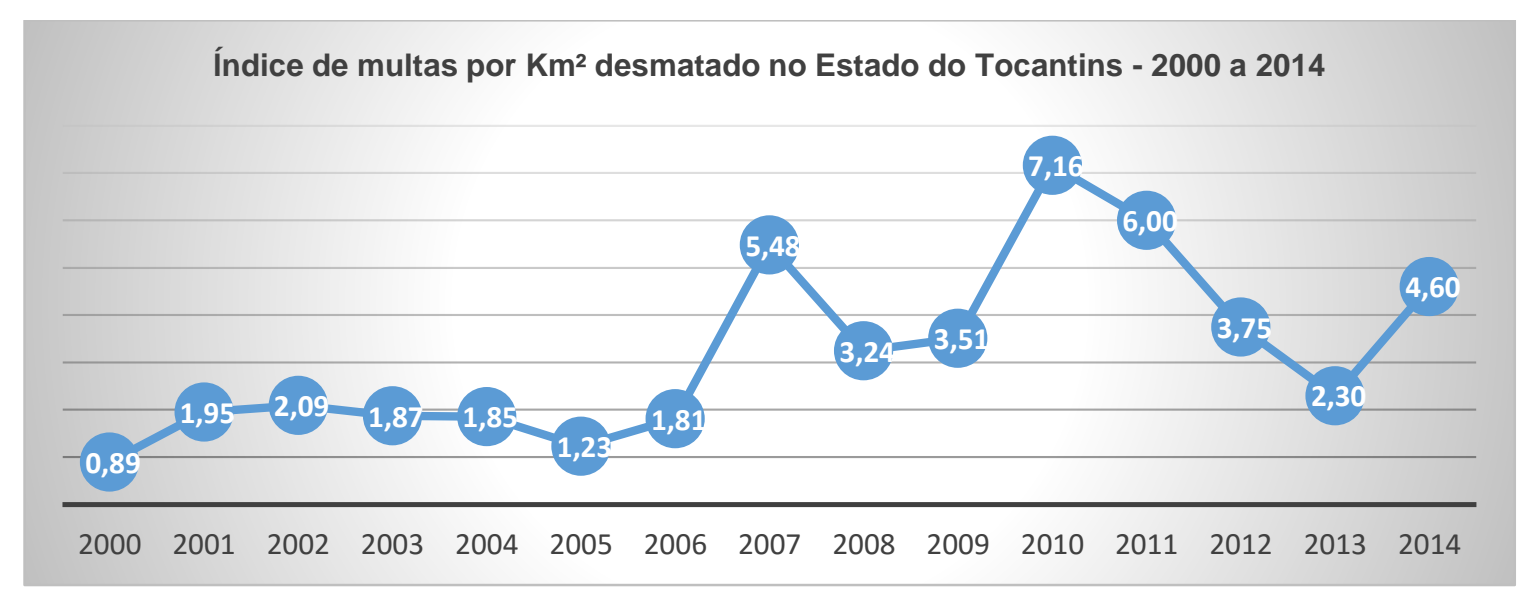

Gráfico 25: Índice de Multas por $\mathrm{Km}^{2}$ desmatado no Estado do Tocantins.

Em 2005, primeiro ano após o lançamento do PPCDAM, o índice de multas por $\mathrm{km}^{2}$ foi menor que em 2004. Em 2006, ele subiu um pouco e, em 2007, o aumento no 
índice foi expressivo. Em 2008, ele voltou a cair e teve uma pequena elevação em 2009. Em 2010, o índice subiu bastante atingindo o seu maior valor histórico. De 2011 a 2013, ocorreu uma sequência de quedas voltando a subir em 2014.

O índice de correlação entre as variáveis taxa de desmatamento e autos de infração lavrados foi de 0,39, ou seja, $r=0,39$. Esse valor de $r$ indica que há uma relação positiva entre essas duas variáveis, ou seja, elas se movem de forma conjunta.

A partir da análise do índice de multas por $\mathrm{km}^{2}$, podemos inferir que a presença mais efetiva do órgão fiscalizador juntamente com adoção de medidas integradas de comando e controle entre diversos órgãos do Estado, após o lançamento do PPCDAM, foram importantes para a queda nos índices de desmatamento no Estado do Tocantins. 


\section{Considerações Finais}

O objetivo do trabalho era mostrar a relação entre autos de infração lavrados e áreas desmatadas na Amazônia Legal. Mostrar se a implantação do PPCDAM e de políticas mais efetivas de controle e combate ao desmatamento tinham sido eficientes na queda das taxas nos últimos anos. O fato é que, após a implantação do PPCDAM, a queda na taxa de desmatamento foi vertiginosa.

A relação entre autos de infração lavrados e áreas desmatadas na Amazônia Legal existe e pode se dizer que, a partir do momento que houve uma maior repressão e punição ao desmatamento ilegal, os índices começaram a cair e atingiram taxas bem abaixo das percebidas desde o início do monitoramento do desmatamento na Amazônia.

Existem vários estudos que relacionam o aumento ou a queda na taxa de desmatamento com os valores das commodities, do preço do gado, do valor da terra, etc. mas existem poucos que tentam compreender a diminuição da taxa a partir da importância que a ação estatal teve sobre esse fato. A principal forma de medir a ação do Estado no combate e repressão ao desmatamento ilegal é a partir da quantidade de autos de infração lavrados.

Se a ideia fosse analisar somente o quantitativo de autos de infração, veríamos que, na Amazônia Legal, nos primeiros anos após o lançamento do PPCDAM, a quantidade de autos lavrados foi muito maior que no período anterior a ele. Esse fato mostra que a presença do Estado também foi importante para a diminuição das taxas.

Com a diminuição da taxa de desmatamento, a tendência é que o número de multas também caísse e foi isso que aconteceu, mas em nenhum momento essa queda representou um aumento considerável na taxa anual de desmatamento.

Mais importante que a aplicação de multas é a presença efetiva dos órgãos do Estado nas regiões onde a ocorrência do desmatamento ilegal era maior. O cidadão deve ter todas as possibilidades para conseguir trabalhar dentro da legalidade e a existência dos órgãos do governo nesses locais pode diminuir a quantidade de pessoas trabalhando na ilegalidade. E para quem não quer trabalhar na legalidade temos o rigor da lei.

A lavratura de autos de infração, além de ser uma forma punitiva, pode atuar como fator educativo, mostrando que se o cidadão cometer aquela ilegalidade será punido. A confiança na impunidade é um dos fatores que tiram o medo das pessoas de cometerem atos ilegais. 
Apesar de em alguns Estados ter ocorrido aumento das taxas de desmatamento em alguns anos após o PPCDAM, de maneira geral, a queda foi considerável. Pensando em termos gerais, de toda Amazônia Legal, essa queda é bem significativa e mostra que aliado a outros fatores que já foram bastante estudados, a existência de políticas públicas comandadas pelo governo federal tem importância na diminuição do desmatamento ilegal na Amazônia Legal.

A partir desse trabalho, pode se continuar tentando entender se existe um espaço temporal entre a lavratura do auto de infração e a queda na taxa de desmatamento, isto é, se a partir da presença efetiva dos órgãos governamentais reprimindo e combatendo o desmatamento ilegal, é possível determinar um tempo médio em que essa atuação é notada com a diminuição da taxa.

O ideal é que se busque a menor taxa possível de desmatamento ilegal e, para isso, é preciso que ocorra cada vez mais o engajamento entre governo federal e sociedade civil. 


\section{Bibliografia}

ARIMA, E. Y.; BARRETo, P.; ARAÚJO, E.; SOARES-FILHO, B. Public Policies can reduce tropical deforestation: Lessons and challenges from Brazil, Land use Policy, vol. 41, p.465-473, 2014. Disponível em: <http://www.elsevier.com/locate/landusepol>

ARRAES, R. A.; MARIANO, F. Z.; SIMONASSI, A. G. Causas do Desmatamento no Brasil e seu ordenamento no contexto mundial, RESR, Piracicaba - SP, vol.50, $\mathrm{n}^{\circ}$, p.119-140, jan/mar 2012

ASSUNÇÃ̃, J.; GANDOUR, C.; ROCHA, R. Deforestation slowdown in the Legal Amazon: prices or policies? CPI. Rio de Janeiro: [s.n.]. 2012. Disponível em: $<$ http://climatepolicyinitiative.org/wp-content/uploads/2012/03/Deforestation-Prices-orPolicies-Working-Paper.pdf $>$

ARPA Biodiversidade

BARRETO, P.; SILVA, D. Will cattle ranching continue to drive deforestation in the Brazilian Amazon? Belém: [s.n.]. Disponível em: $<$ http://www.imazon.org.br/publicacoes/congressos-e-anais/will-cattle-ranchingcontinue-to-drive >

BECKER, B. Geopolítica da Amazônia. Revista Estudos Avançados, vol. 19, n.53, p.71-86, abril, 2005.

EWERS, R.; LAURANCE, W.; Deforestation in Amazônia. Environmental Conservation, vol. 33, n.3 p.203-211, 2006.

FEARNSIDE, P.M. Desmatamento na Amazônia Brasileira: história, índices e consequências. Revista MEGADIVERSIDADE, vol.1, n.1, julho. 2005.

FEARNSIDE, P.M. Desmatamento na Amazônia: Dinâmica, Impactos e Controle. Revista Acta Amazônica, vol.36, n.3, p.395-400, 2006.

GAZONI, J. L.; MOTA, J. A. Fatores Político-Econômicos do Desmatamento na Amazônia Oriental. Revista Sustentabilidade em Debate, vol.1, n.1, p. 25-42, 2010

GEORGE, Pierre. Os Métodos da Geografia. Trad. Heloísa Dantas. São Paulo: Diefel, 1986, p.7-58;114-119.

GODAR, J.; TIZADO, E.; POKORNY, B.; Who is responsible for deforestation in the Amazon? A Spatially explicit analysis along the Transamazon Highway in Brazil. Forest Ecology and Management, vol. 267, p.58-73, 2012.

HOMMA, A.K.O. Política agrícola ou ambiental para a prese(conse)rvação da Amazônia? Revista de Política Agrícola. Brasília, v. 5, n. 4, p.16-23, 1996

KIRBY, K.; LAURANCE, W.; ALBERNAZ, A.; GOTZ, S.; BERGEN, S. et. all. The future of deforestation in the Brazilian Amazon. Futures, vol. 38, p.432-453, 2006.

KOSIK, Karel. Dialética da totalidade concreta. In: Dialética do Concreto. Trad. Célia Neves e Alderico Toríbio. Rio de Janeiro: Paz e Terra, p.11-64, 1976.

LAURANCE, W.; VASCONCELOS, H. Consequências Ecológicas da Fragmentação Florestal na Amazônia. Oecologia brasiliensis, 13(3), p.434-451, 2009. LAURANCE, W.; ALBERNAZ, A.; FEARNSIDE, P.; VASCONCELOS, H.; FERREIRA, L. Deforestation in Amazônia. Science, vol. 304, p.1109-1110, Maio, 2004.

MACHADO, Luciana. Desflorestamento na Amazônia Brasileira: ação coletiva, governança e governabilidade em área de fronteira. Revista Sociedade e Estado, Brasília, vol.24, n.1.p.115-147, Jan/Abr 2009. 
MACHADO, Ricardo B.; Aguiar, Ludmilla, S. A.; Desmatamentos na Amazônia e consequências para a biodiversidade. In: Causas e dinâmica do desmatamento na Amazônia. Brasília: MMA, 2001.

MARGULIS, S. Causas do desmatamento na Amazônia Brasileira. $1^{\text {a }}$ edição, 100p., Brasília, 2003.

MORAES, Antônio C. R. Meio ambiente e ciências humanas. São Paulo: Annablume, p.45-80, 2005.

NEPSTAD, D.; SOARES-FILHO, B.; MERRY, F.; LIMA, A.; MOUTINHO, P. et. all. Deforestation in Amazônia. Science, vol. 326, p.1350-1351, Dezembro, 2009.

NEPSTAD, D.; McGRATHY, D.; STICLER, C.; ALENCAR, A.; AZEVEDO, A. et. all. Slowing Amazon deforestation through public policy and interventions in beef and soy supply chains. Science, vol. 344, p.1118-1123, Junho, 2014.

NOLTE, C.; AGRAWAL, A.; SILVIUS, K.; SOARES-FILHO, B. S. Governance regime ans location influence avoided deforestation sucess of protected áreas in the Brazilian Amazon. PNAS, vol. 110, n.13, p.4956-4961, Março, 2013.

PRATES, R. C. O desmatamento desigual na Amazônia brasileira: sua evolução, suas causas e consequências sobre o bem-estar. Tese de Doutorado, Escola Superior de Agricultura Luiz de Queiroz. Piracicaba, 2008.

PRODANOV, C.C.; FREITAS, E.C. Metodologia do trabalho científico: métodos e técnicas de pesquisa e do trabalho acadêmico. $2^{\text {a }}$ edição, Novo Hamburgo - RS: Feevale, 2013.

REYDON, P. B. O desmatamento da floresta amazônica: causas e soluções. In: Política Ambiental / Conservação Internacional - n. 8. Jun. 2011 - Belo Horizonte: Conservação Internacional, 2011

RIVERO, S.; ALMEIDA, O.; ÁVILA, S.; OLIVEIRA, W.; Pecuária e desmatamento: uma análise das principais causas diretas do desmatamento na Amazônia. Revista Nova Economia, Belo Horizonte - MG, vol.19, n.1, p.41-66, jan/abr, 2009

SILVA, Armando C. A aparência, o ser e a forma (Geografia e Método). Revista GEOgraphia, Niterói, Ano II, no 3, p. 7-25.

SOARES-FILHO, B. S.; NEPSTAD, D.; CURRAN, L.; CERQUEIRA， G. C.; GARCIA, R. A.; RAMOS, C. A.; VOLI, E.; MCDONALD, A.; LEFEBVRE, P.; SCHLESINGER, P.; MCGRATH, D. Cenários de Desmatamento para a Amazônia. Estudos Avançados 19(54), 2005, p. 137-151 